\title{
Generic revision and phylogenetic analysis of the Metriorrhynchinae (Coleoptera: Lycidae)
}

\author{
LADISLAV BOCAK \\ Faculty of Science, Palacký University, tř. Svobody 26, 77146 Olomouc, Czech Republic; e-mail: ladislav.bocak@upol.cz
}

Key words. Coleoptera, Metriorrhynchinae, generic revision, phylogeny, taxonomy, key, World

\begin{abstract}
The subfamily Metriorrhynchinae is the most species-rich clade of Lycidae (Coleoptera). A recent proposal suggests that the Erotinae is a sister group of the Metriorrhynchinae. Within the Metriorrhynchinae, evidence is presented for the monophyly of the Conderini and Metriorrhynchini and their sister group position. The Trichalina, Hemiconderina and Metriorrhynchina form the tribe Metriorrhynchini. The relationships between the basal lineages of this group are poorly understood. Several clades are distinguished within the Metriorrhynchina, but there is only weak evidence supporting a relationships between them. The distribution of individual clades is discussed. Carathrix Kleine, 1926 (= Pseudodontocerus Pic, 1921), Dilolycus Kleine, 1926 (= Metriorrhynchus Gemminger et Harold, 1869), Flabelloporrostoma Pic, 1923 (= Metriorrhynchus Gemminger et Harold, 1869), Rossioptera Kasantsev, 1988 (= Xylobanellus Kleine, 1930), Samanga Pic, 1921 (= Broxylus C.O. Waterhouse, 1879), Strophicus C. O. Waterhouse, 1879 (=Enylus C.O. Waterhouse, 1879), and Tapromenoeus Bocak et Bocakova, 1989 (= Prometanoeus Kleine, 1925) are proposed as junior synonyms. Pseudosynchonnus Pic, 1922 is transferred to the Erotinae (Taphini) and Pseudosynchonnus Pic, 1922, Protaphes Kleine, 1926, and Parapyropterus Kleine, 1926 are proposed to be junior subjective synonyms of Lycoprogenthes Pic, 1915. Redescriptions of Metriorrhynchinae genera and a key to genera are provided.
\end{abstract}

\section{INTRODUCTION}

The Metriorrhynchinae is the largest subfamily of Lycidae, both in the number of genera and number of species. Kleine (1933) listed in the last World Catalogue about 1200 species in 41 genera now classified in this subfamily. That is, in terms species this subfamily make up over 40 percent of the Lycidae. Most Metriorrhynchinae are from Southeast Asia, the Indonesian Archipelago, New Guinea and Northern Australia. Further species occur in Africa, Madagascar, temperate Asia, Ceylon, and India. Only one species occurs in Eastern Europe and in Siberia. Within Lycidae, Metriorrhynchinae are defined by their circular phallobase (Figs 91-132), flat, conspicuous, unpaired vaginal gland in most representatives (Figs 143-160), and a pronotum with lanceolate median areola, usually with lateral and frontolateral pronotal carinae (Figs 57-86). Metriorrhynchinae appear to be close to the Erotinae as they have very similar pronotal carinae in some forms, structurally similar elytral costae, male and female genitalia similar in some features, and generally similar larvae (Bocak and Matsuda, in press).

Fabricius (1775) described the first species that is now placed in Metriorrhynchinae (Pyrochroa serraticornis now classified in Trichalus) and later proposed several additional species (Fabricius, 1801). Numerous entomologists working on the material collected by scientific expeditions in the first half of the XIXth century (Dalman, Fåhraeus, Macleay, Hope, Klug, and Boisduval) followed Fabricius. They described few species and classified them in then genera Lycus F., 1787, Calopteron Castelnau, 1838, or Dictyoptera Latreille, 1829. GuérinMéneville $(1830,1838)$ and Castelnau $(1838)$, were the first to introduce the genera of Metriorrhynchinae to lycid classification: Cladophorus Guérin-Méneville, 1830 , Metriorhynchus Guérin-Méneville, 1838, and Porrostoma Castelnau, 1838. Various authors disagreed with the dating of their descriptions, and the validity of these taxa was clarified much later by Bocak (1998c). Numerous authors added further species to various genera (e. g. Erichson, Blanchard, Thomson, Walker, Motschulsky, Redtenbacher, Kiesenwetter, and Kirsch). C.O. Waterhouse $(1877,1879)$ alone proposed thirteen new genera which still form the backbone of Metriorrhynchinae classification. He described also numerous new species from different parts of the Metriorrhynchinae range of distribution. Further species were proposed in the last decades of the XIXth century (Blackburn, Bourgeois, Fairmaire, Gorham, Harold, Kirsch, Kiesenwetter, Lea, W. M. Leay, and Schaufuss). Only two authors, R. Kleine and M. Pic, contributed substantially to the knowledge of Lycidae before World War II. They described hundreds of new species and several new genera. Kleine and Pic defined genera mostly on the basis of the presence or absence of secondary costae, flabellate antennae or the number of pronotal carinae. Congruence of these criteria with other characters needs to be established. Unlike Pic, Kleine dissected genitalia, but preferred other characters for classification. Consequently, Kleine (1926a) classified Metriorrhynchus parallelus in Cladophorus on the basis of its flabellate antennae, although it is the type species of Metriorrhynchus, which he recognised.

Only a few species were described after World War II. Nakane $(1968,1969 a, b, 1971,1980)$ studied the fauna of Japan and Taiwan, Kasantsev (1988) described the genus Rossioptera (= Xylobanellus Kleine) from Russia, but he did not classify it in the Metriorrhynchinae. Bocak \& 
Bocakova (1987b, 1989, 1990b, 1991, 1999), Bocak (1998a, b, d, e, 1999a, b, 2000a, b, c, d, 2001a, b), and Bocak \& Matsuda (1998) published several geographically limited revisions and descriptions of new species from the Oriental Region and New Guinea. Bocak (1998c) solved the long lasting uncertainty about the status of the genera described by Guérin-Méneville. Calder (1998) compiled a catalogue of Australian Lycidae and proposed 85 new combinations within the Porrostoma. These new combinations were not based on the study of type specimens, and therefore the generic classification of Australian Lycidae remains obscure.

At present, the entire classification of the Metriorrhynchinae at the species and generic levels is chaotic. A large part of this confusion results from the inadequate nature of Pic's descriptions and unclear reasons for his proposals. He thought that as his descriptions were long they would be useful (W. Wittmer, pers. comm.). As Kleine usually ignored Pic's descriptions, revisions of most genera are urgently needed.

The subfamily Metriorrhynchinae was proposed by Kleine (1926a), along with the subfamily Dilolycinae (=Haplothoracinae, nomen nudum). Later he described the subfamilies Trichalinae and Cladophorinae (Kleine, 1928). Kleine (1933) designated all these taxa as tribes of Lycinae. Bocak \& Bocakova (1990a) proposed the tribe Conderini and subtribe Hemiconderina, synonymised Cladophorinae and Dilolycinae with Metriorrhynchinae and downgraded Trichalinae to the subtribal level. Metriorrhynchinae was made up of two tribes, Conderini and Metriorrhynchini, the later being divided to the subtribes Trichalina, Metriorrhynchina and Hemiconderina. Bocak (1998b) revised the generic classification of the Trichalina.

The species richness and high endemism in the transitional Austro-Oriental zone, as well as the restriction of Lycidae to moist forests and usually to mountainous habitats, suggest that Metriorrhynchinae could be a valuable model group for evolutionary and zoogeographical studies. This characteristic is combined with the fact that Lycidae are models in numerous mimicry complexes. Despite all this, the poor knowledge of Metriorrhynchinae has prevented them from being used for more general studies. Research on this group has suffered from the absence of comprehensive definitions of genera as well as the doubtful phylogenetic affinities between genera and tribes. This paper should establish the basis for further study of this extremely diverse group.

\section{Natural history}

Metriorrhynchinae are one of the commonest groups of Lycidae in tropical Asia and Australia. The adults live mostly on the leaves of shrubs and herbs in dense forest canopy. Although most specimens in museum collections were collected individually or by sweeping of the lower strata of tropical forests, Metriorrhynchinae are active also in the upper strata as shown by the material obtained by insecticidal fumigation in Sulawesi (Bocak, 2000c). They are generally slow moving and fly only occasionally and reluctantly. The highest dispersal activity was observed in early morning and shortly before sunset. Some species are attracted to light but the proportion of Lycidae collected at lights is generally low. Unlike Lycinae, the Metriorrhynchinae are rarely attracted to flowers. Leptotrichalus are the only Metriorrhynchinae regularly collected on flowers in South East Asia. Flowers in Australia attract at least some species of Porrostoma and Trichalus. Larvae were collected in decaying wood. Lycidae generally seek moist conditions and inhabit rotten trunks or branches in shaded places, often laying on the ground and in close contact with moist soil. Several larvae of Metriorrhynchinae have been described. Burakowski (1988) described the larva and pupa of Xylobanellus erythropterus; Hayashi (1954), Fukuda \& Hayashi (1981), and Hayashi (1986) described several Japanese species of Cautires. Potozkaja (1981) described the larva of Xylobanus angusticollis (Motschulsky). Other larvae of Metriorrhynchinae were reported recently by Bocak \& Matsuda (in press). Metriorrhynchinae are often involved in Müllerian mimicry complexes, Lawrence \& Britton (1991) mentioned those from Australia. Moore \& Brown (1981) studied the antifeedants in the body of Porrostoma rhippidium (W. M. Leay, 1827).

\section{MATERIAL AND METHODS}

\section{Taxa}

Altogether 45 genera were classified in the Metriorrhynchinae and Bocakova (in press) transferred Broxylus to the Metriorrhynchinae: for a list of genera see Appendix 1. The phylogenetic analysis deals with 34 genera of Metriorrhynchinae. One of Metriorrhynchinae genera was found to be a member of the Erotinae (Pseudosynchonnus). Four genera were synonymised prior the analysis, because they did not differ from genera included in the analysis: Dilolycus (= Metriorrhynchus), Flabelloporrostoma (= Metriorrhynchus), Samanga (= Broxylus), and Strophicus (= Synchonnus). One genus was not found in Pic's collection and its identity is unknown (Falsolucidota). The genera Mimoxylobanus, Oriomum, Cladophorinus, Xylobanomorphus, Xylobanomimus, and Malacolycus are available only as single specimens of one sex, and therefore they were excluded from the analysis. Their redescriptions and discussion of their possible systematic position are given in the taxonomic part. The proportion of unknown character states is very high for these genera and this uncertainty collapsed the basal part of the tree of Metriorrhynchini to the unresolved bush. Wiens (1998) discussed the consequence of a high proportion of missing data. All the genera excluded from the analysis as well as genus of unknown identity are monotypic, therefore their exclusion did not restrict substantially the scope of the analysis. All type species of Metriorrhynchinae genera were studied except Falsolucidota Pic, 1921b, which should be deposited in the National Museum of Natural History in Paris, but was not found in Pic's collection.

Bocak \& Bocakova (1990a) reclassified the Metriorrhynchinae. Evidence for monophyly was sought in the morphology of the ingroup and trees were rooted using the outgroup method (Watrous \& Wheeler, 1981). A sister-group for the Metriorrhynchinae was not suggested by previous authors and the possibility of a close relationship between Erotinae and Metriorrhynchinae based on larval characters was briefly discussed by Bocak \& Matsuda (in press). In addition, Erotinae and Metriorrhynchinae have the same arrangement of elytral costae, carinae on the pronotum and slender parameres (present only in 

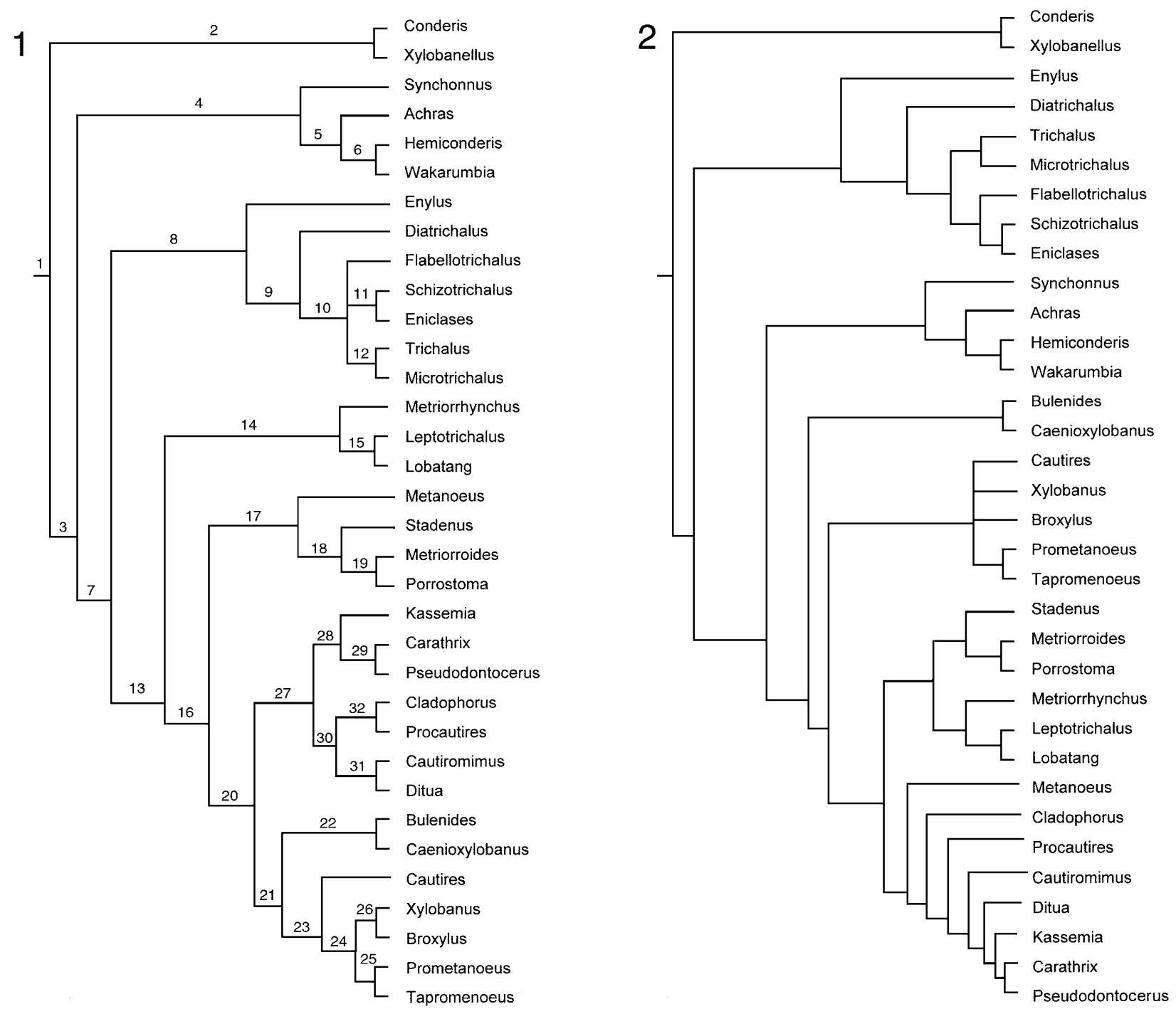

Figs 1-2: Cladograms. 1 - the strict consensus tree derived from three trees provided by an analysis of the matrix in Table 2 (mh*, $\left.b^{*}\right) ; 2$ - the strict consensus tree based on two trees obtained after application of successive weighting. The numbers above branches correspond to node numbers in Tab. 3 .

Conderini within the Metriorrhynchinae). The phylogeny of Lycidae has not yet been analysed, and therefore multiple outgroups were chosen and the impact of switching to different outgroups tested. The following taxa were used as outgroups: Dictyoptera (represented by D. aurora (Herbst)) and Pyropterus (P. nigroruber (Degeer)) from Erotinae as presumably the closest sister-group, Lyponia (L. (Ponyalis) laticornis Fairmaire), which is considered to be the most basal member of Platerodinae (Bocakova, 2001), and Calochromus (Calochromus sp. from Yunnan) from the Calochrominae. Dictyoptera and Pyropterus represent genera that have and lack secondary elytral costae. This character was thought to be important for the generic classification of Lycidae. The selected outgroups represent all potential relatives of Metriorrhynchinae. The remaining subfamilies of Lycidae differ substantially in adult and larval characters (Lycinae: Lycini and Macrolycini) and in addition some of them have neotenous females (Duliticola, Platerodrilus, presumably Ateliinae, Leptolycinae: Dexorini).

\section{Characters}

I identified 72 characters, 67 potentially informative for the relationships within an ingroup and five of them constant within an ingroup and used for its definition. Polymorphic characters in terminal taxa were coded as "-" in the matrix, and all characters are described in Table 1. Autapomorphic characters of individual genera were not included and they are discussed in the taxonomic part. When possible, several species of each genus were scored for each character. The genera included in the analysis were always available as type(s) or identified specimens of type species of both sexes. In several cases, data from disarticulated closely related species were compared with the type species. Because of the danger of inappropriate sampling, the examination of several representatives of each genus was preferred. This was easy in case for recently revised genera, but difficult in the case of the very large genera used by M. Pic (Metriorrhynchus, Cladophorus, Cautires), for genera typologically consisting of very diverse groups of unrelated species (Procautires) or genera formally monotypic but based on numerous undescribed species. I preferred to score the group of species closely related to the type-species. An alpha-taxonomic study of such genera was beyond the scope of this paper. 

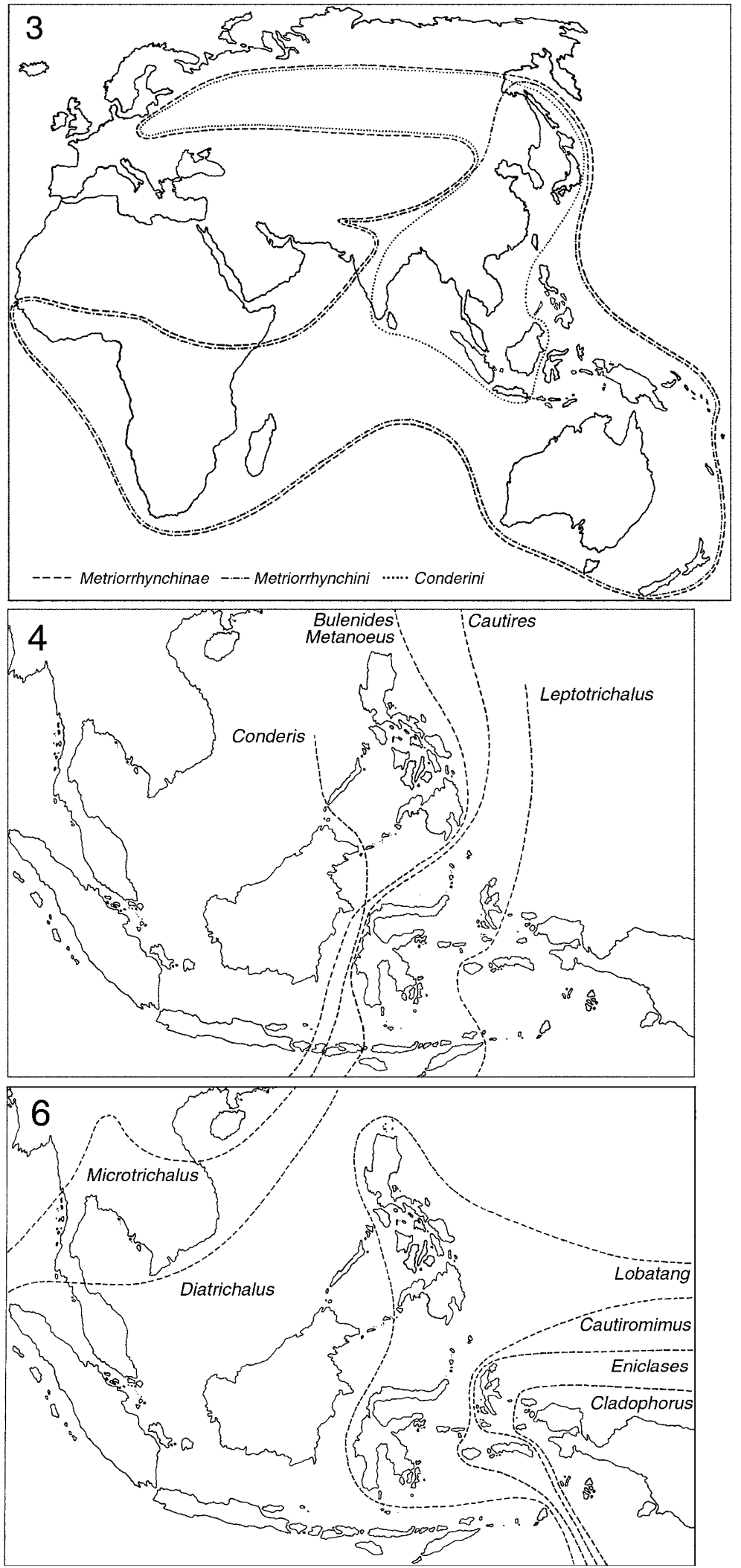

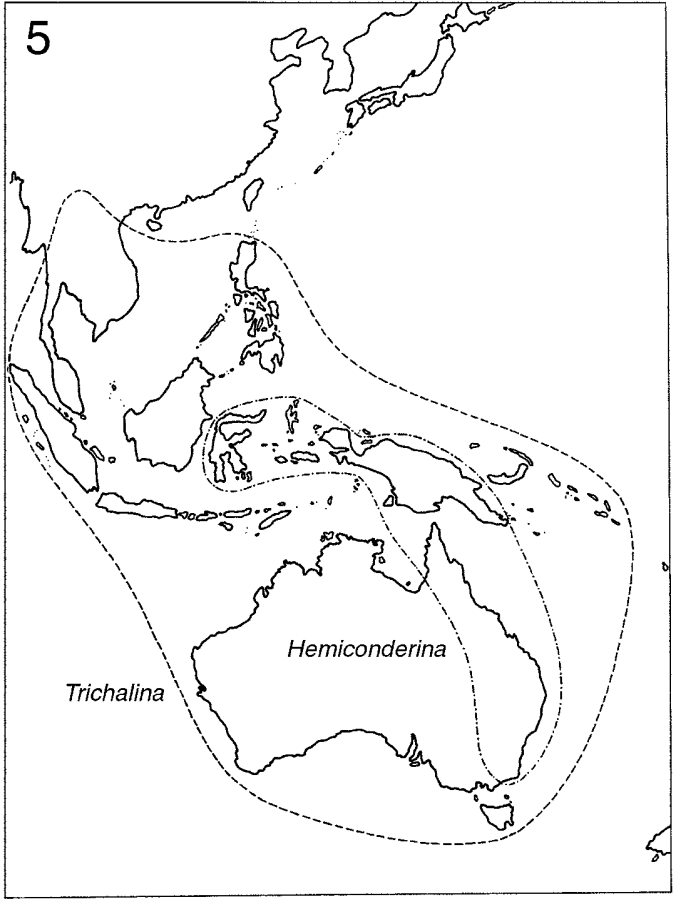

Figs 3-6: Distribution. 3- distribution of subfamily and tribes; 4 - eastern limit of range of Asian continental elements; 5 - distribution of Hemiconderina and Trichalina; 6 - western limit of range of Australian elements.

The present study is based exclusively on adults. Both male and female genitalia of all available type specimens were dissected and the membranous parts stained lightly with chlorazol black. Important characters were drawn using an ocular grid- screen or illustrations were derived from photographs taken with an Olympus DP-10 or Camedia 3000 digital camera attached to an Olympus SZX-12 stereoscopic microscope. 

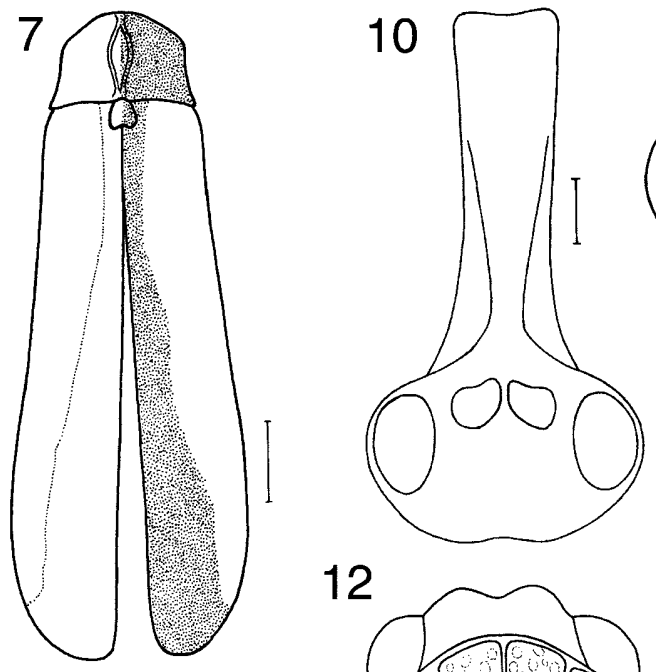

12
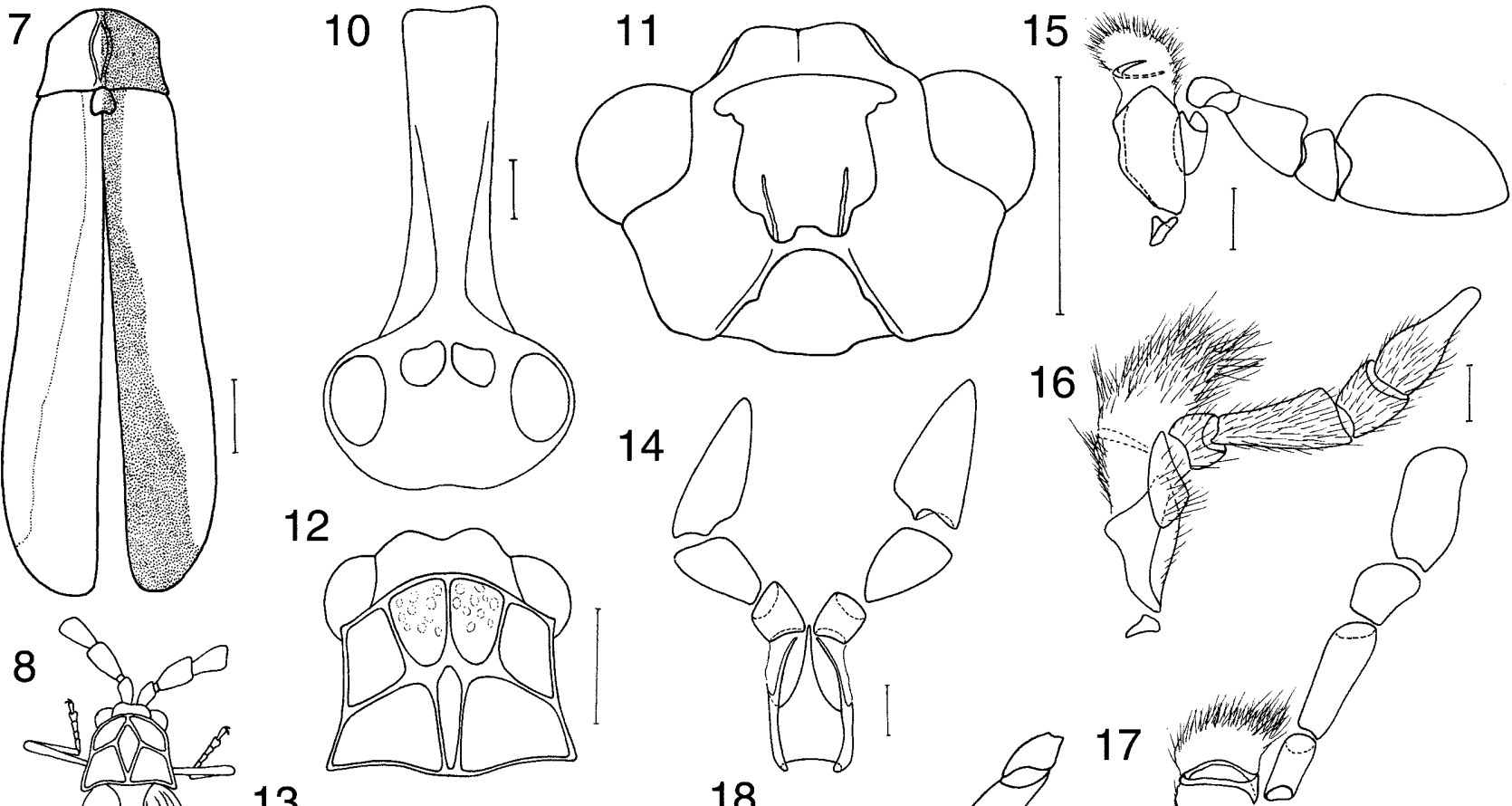

14

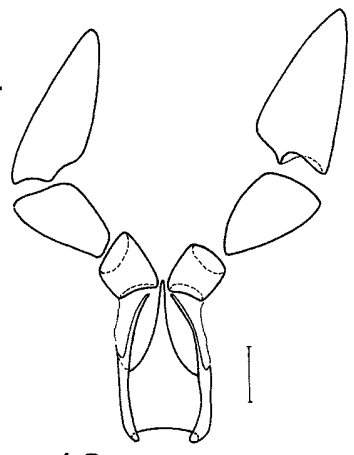

16
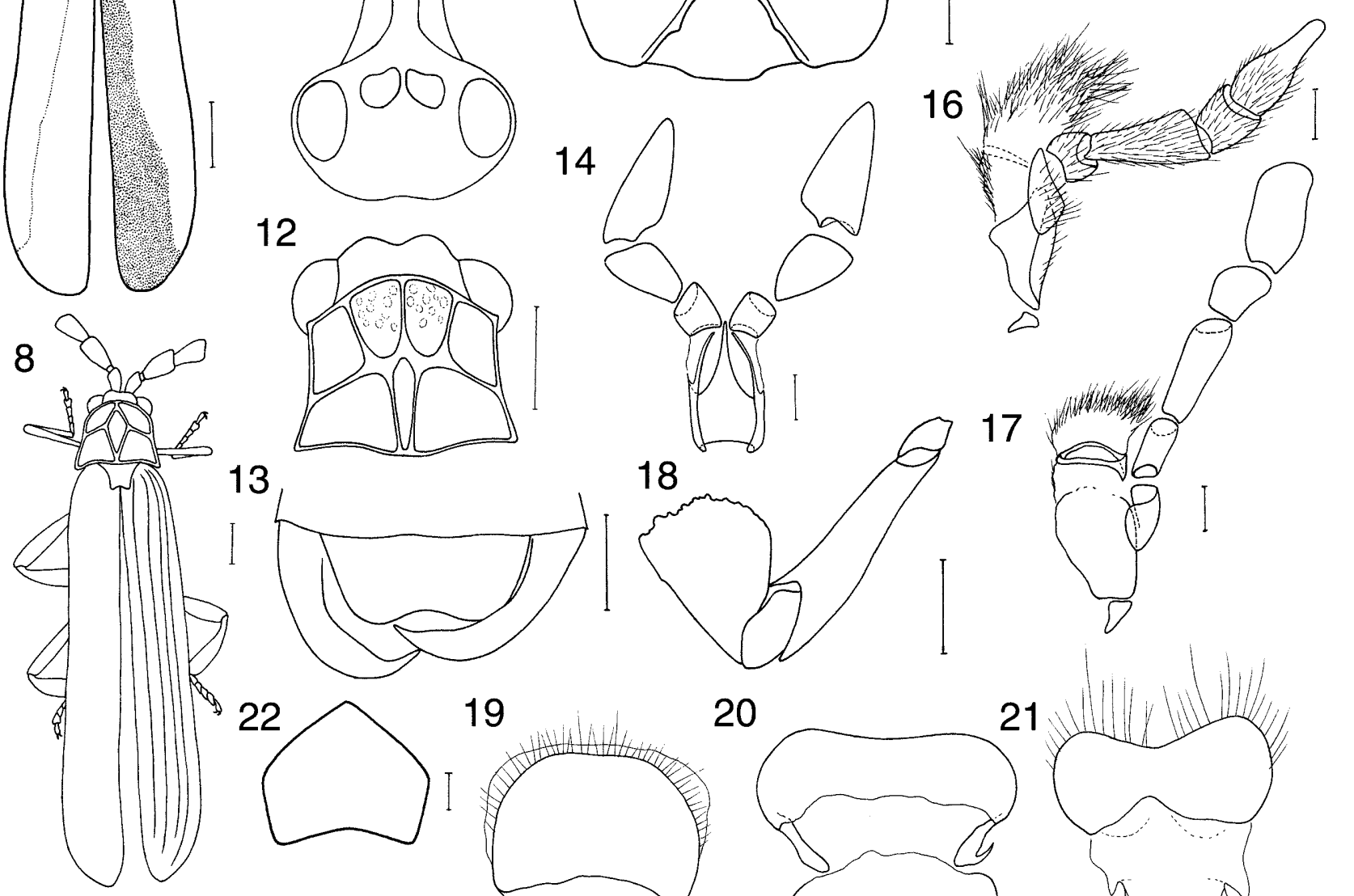

13

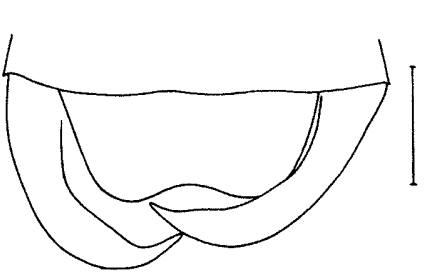

18

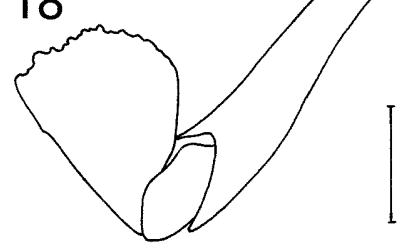

17
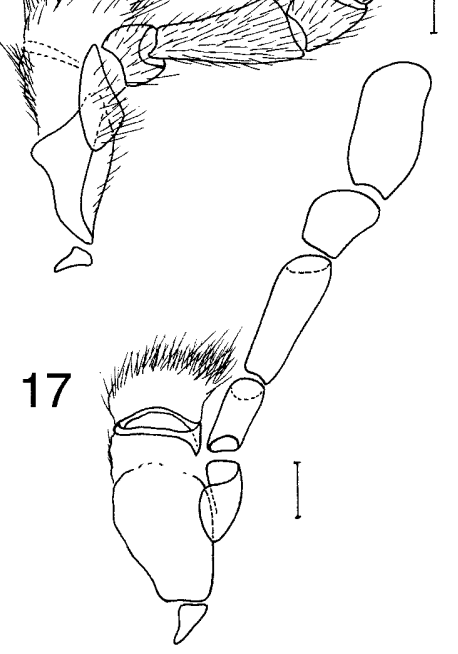

9
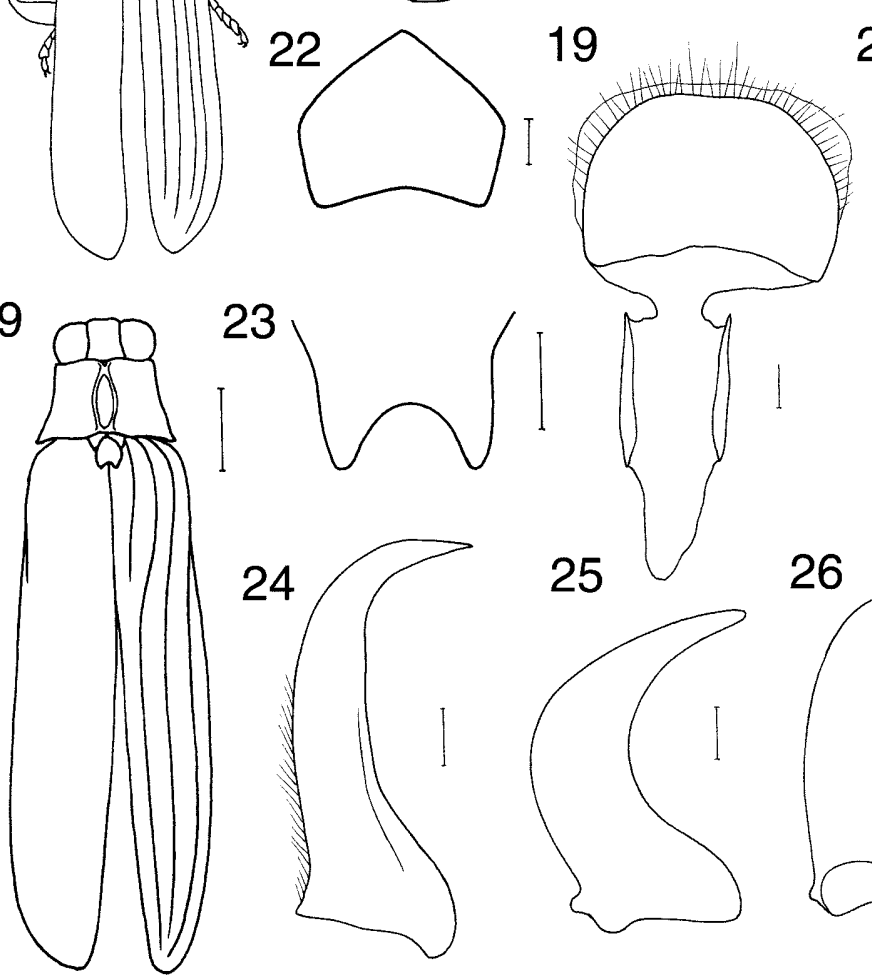

20

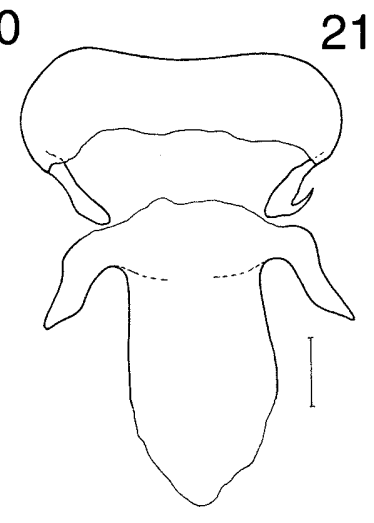

21

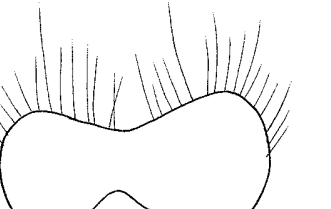

23
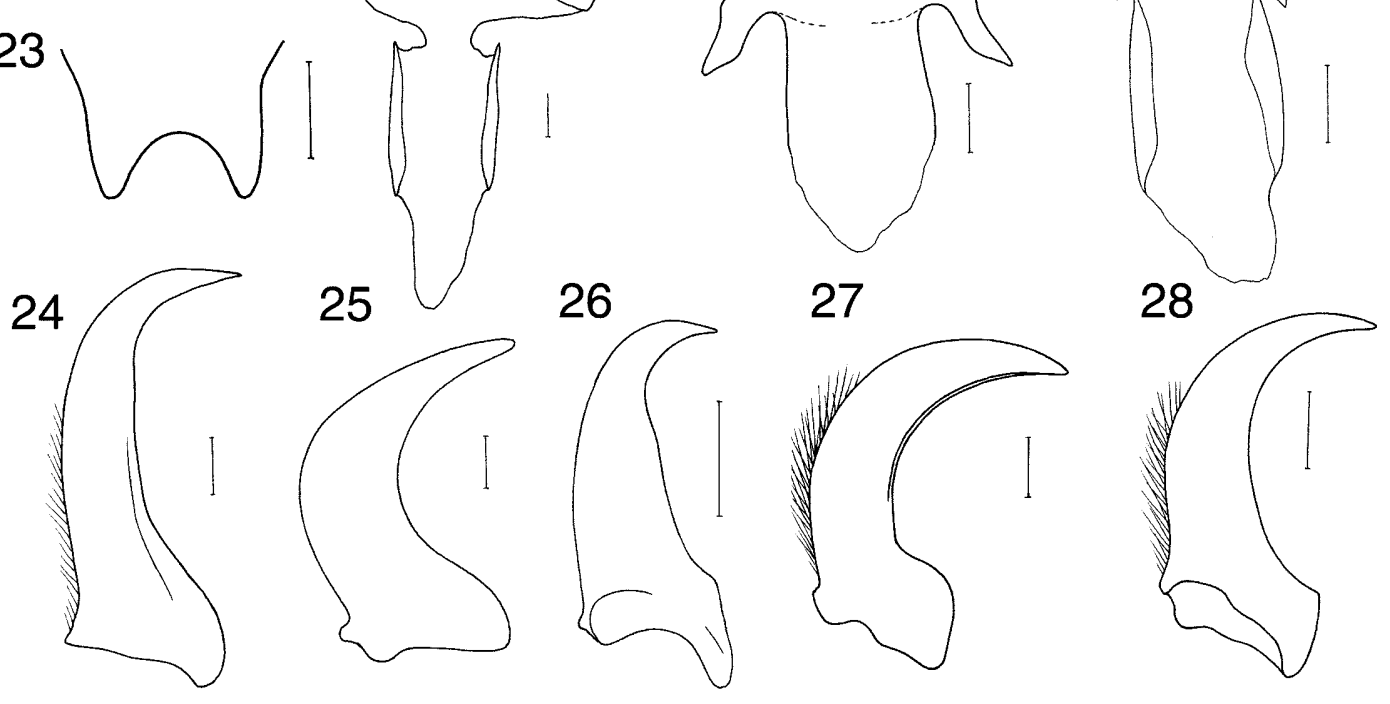

Figs 7-28: 7-9. General appearance. 7 - Enylus amplus; 8 - Wakarumbia grandis; 9 - Lobatang sordescens; 10-11. Head. 10 Porrostoma rhippidium; 11 - Diatrichalus sp.; 12 - pronotum, Metriorrhynchus fessus; 13 - labrum, Pseudodontocerus pulcher; 14 - labium, Metriorrhynchus parallelus; 15-17. Maxilla. 15 - Broxylus fenestratus; 16 - Prometanoeus ochraceus; 17 - Metanoeus sp.; 18 - maxillary palpus, Pseudodontocerus pulcher; 19-21. Labrum and hypopharynx. 19 - Metriorrhynchus parallelus; 20 Conderis signicollis; 21 - Metanoeus sp.; 22-23. Scutellum. 22 - Schizotrichalus nigrescens; 23 - Metriorrhynchus mirabilis; 24-28. Mandible. 24 - Metriorrhynchus parallelus; 25 - Conderis signicollis; 26 - Broxylus fenestratus; 27 - Pseudodontocerus sp.; 28 - Cladophorus sp. Scale $0.5 \mathrm{~mm}$ (Figs 1-6, 17), $0.2 \mathrm{~mm}$ (Figs 7, 12), $0.1 \mathrm{~mm}$ (Figs 8-11, 13-16, 18-22). 
TABLE 1. List of characters and character states used in the cladistic analysis of Metriorrhynchinae

\begin{tabular}{ll}
\hline 1 & Rostrum \\
2 & Clypeo-genal suture \\
3 & Gula \\
4 & Frontal margin of clypeus \\
5 & Apex of labrum \\
6 & Labral arms \\
7 & Mandibles \\
8 & Molar \\
9 & Ventral mandibular condyle \\
10 & Apical segment of maxillary palpus \\
11 & Tubercles on margin of terminal maxillary palpomere \\
12 & Tubercles on margin of terminal labial palpomere \\
13 & Antennae \\
14 & Male antennomeres 3-10 lamellae
\end{tabular}

15 Male antennomeres 3-10

16 Length of antennomere 2

17 Female antennae

18 Frontolateral pronotal carinae

19 Lateral pronotal carinae

20 Frontal margin of pronotum

21 Median areola

22 Median areola/frontal margin

23 Shape of median areola

24 Base of pronotum

25 Number of pronotal areoles

26 Shape of pronotum

27 Pronotal carinae

28 Lateral margins of pronotum

29 Secondary elytral costae

30 Primary elytral costa 1

31 Primary elytral costa 3

32 Strength of costae

33 Elytral cells

34 Process of mesothoracic spiracular plate

35 Metascutellar hind margin

36 Mesoscutellar lateral process

37 Lenght of alacrista

0 , absent (Fig. 11); 1, present (Fig. 10)

0 , absent or unclear; 1 , short; 2 , long

0 , longitudinal or rectangular; 1 , transverse (Fig. 11)

0 , convex; 1 , concave; 2 , straight; 3 , bisinuate; 4 , shallowly emarginate

0 , simply rounded; 1 , emarginate (Figs 19-21)

0 , long, slender; 1 , with stout base; 2 , fused with lateral margin of labrum

0, long, stout, considerably curved (Fig. 25, 27, 28); 1, small, slender

(Fig. 24); 2, small, slender with apex curved at a right angle

0 , present, or at least mandibular base robust (Figs 25-28); 1, absent (Fig. 24)

0 , ventrally directed; 1 , caudally directed, robust; 2 , caudally directed, weak

0, robust (Fig. 15); 1, slender (Fig. 16-17)

0, absent (Fig. 15-17); 1, present (Fig. 18)

0 , absent (Fig. 14); 1, present

0 , rounded in cross-section; 1 , considerably compressed

0, with wide lamellae, serrate, filiform (Figs 29-39); 1, with slender lamellae

0 , filiform or serrate; 1, flabellate (Fig. 38)

0 , comparable with antennomere $3 ; 1$, considerably shorter (Fig. 29-51)

0, serrate or filiform (as in Fig. 30); 1, flabellate (Figs 46-47)

0 , absent (Figs 57-65); 1, present or at least vestigial (Figs 69-83)

0, present (Figs 57-59, 69-83); 1, absent or vestigial (Figs 61-68)

0, simple Figs 57-66, 69-86); 1, strengthened, formed by two carinae (Figs 67-68)

0 , constricted at base; 1 , not constricted (Figs 87-86)

0 , directly attached (Fig. 61); 1, connected by costa (Figs 57-59, 62-86)

0 , in middle, usually large (Figs 57-61); 1, small, short, attached to pronotal base (Figs 68-73, 77-86); 2, slender, Trichalus type (Figs $62-65)$

0 , with symmetrical bulges; 1 , without symmetrical bulges

0 , less than seven (Figs 57-68); 1, seven (Figs 71-83)

0 , with apparent frontal angles and elevated lateral margins (Figs 57-73, 75-80); 1, rounded frontal angles, compact lateral margins (Figs 74, 81)

0 , robust, obtuse; 1 , slender, straight (Figs 59-60)

0, without tubercles (Figs 57-59); 1, with tubercles (Figs 61-66); 2, slightly widened before base (Figs 76,78)

0 , fully developed (Figs 52-55); 1, present only close to humeri; 2; completely absent (Fig. 87); 3; absent only in middle part

0 , fully developed (Fig. 8); 1; considerably shortened (Fig. 9)

0 , full; 1 , weaker at apex; 2 ; considerably shortened; 3 , absent

0 , equal; 1 , costae 2 and 4 much stronger, or at least costa 2 stronger

0, transverse or rectangular (Fig. 55); 1, rounded, small (Fig. 54)

0 , absent; 1 , short; 2 , long; 3 , without process, spiraculum in form of large tube

0 , emarginate with keel; 1 , straight without keel; 2, straight with keel

0 , absent or short; 1 , long

0 , as long as scutoscutellar suture or longer; 1 , distinctly shorter 
Table 1 (continued).

38 Width of mesosternal process
39 Tibial spurs on hind legs
40 Apical part of phallus
41 Phallus short, wide, robust
42 Phallus lanceolate, widest at apex
43 Phallus slender, narrows at apex, membranous ventrally
44 Phallus slender, tubular
45 Internal sac

0 , wide; 1 , narrow

0 , present; 1 , absent; 2 , very short

0 , rounded in cross section or dorsoventrally compressed; 1 , considerably laterally compressed

0 , no; 1, yes (Figs 122, 125, 127)

0, no; 1, yes (Figs 92, 107, 108, 109)

0 , no; 1, yes (Figs 103, 104)

0, no; 1, yes (Figs 117-120)

0, membranous, without sclerotized structures (Fig. 91); 1, with two apical paired spines (Figs 107-110); 2, with two basal paired spines (Figs 125, 127); 3, linearly arranged spines; 4, spines fused (Fig. 94); 5, with stick-like structure (Fig. 121); 6, phallus with unique structure apically (Figs 100-101)

46 Internal sac with sclerotised plates or ducts $\quad 0$, no; 1, yes (Figs 121-123, 125-126)

47 Phallus very slender, with weakly bulbous base, apex 0, no; 1, yes (Fig. 94) often rotated

48 Process at bases of paramerae

0 , absent; 1 , present

49 Phallus with dorsal keel

0, no; 1, yes (Figs 105, 106)

50 Base of phallus

0, straight; 1, hook-like (Fig, 91)

51 Basal tubercle of phallobase

0 , absent; 1 , present

52 Internal sac

0, completely membranous, colourless, retracted in phallus (Fig. 91);

53 Primary gonoporus

1 , exposed, at least partly sclerotized or coloured

54 Parameres

0 , membranous; 1, sclerotized (Figs 122, 125, 126)

55 Shape of basal part of phallus

0 , present; 1,absent (Figs 92-132)

56 Symmetry of basal part of phallus

0 , fused with basal part of parameres; 1, simply narrowed (Fig. 112);

2, obtuse or widened (Fig. 121, 127]

0, symmetrical (Fig. 112); 1, asymmetrical, type Metriorrhynchus (Fig. 114-116); 2, asymmetrical type Trychalus (Fig. 104)

57 Phallobase

0 , elongate; 1 , circular

58 Basal margins of coxites

0 , strengthened; 1 , simple; 2 , plate-like

59 Phallobasal membrane

0 , soft, colourless; 1, pigmented, sometimes sclerotised (Figs 114-116)

60 Valvifers fused with coxites

0 , no; 1, yes (Fig. 156, 159)

61 Valvifers distinctly widened medaslly

0 , yes; 1 , no (Fig. 133)

62 Valvifers

0, much longer than coxites; 1, moderately long (Figs 151-153); 2, shortened, widened at apex (Fig. 136); 3, vestigial (Fig. 150)

63 Lateral glands with narrow ducts

0, no (Fig. 142); 1, yes (Figs 147-160)

64 Unpaired gland

0 , absent or minute, filiform (Fig. 142); 1, flat, distinct (Fig. 147)

65 Lateral glands

0 , inserted apically or laterally (Fig. 147); 1 ; inserted dorsally

66 Spermatheca

0 , bulbous at least apically (Figs 142-144); 1, very slender

67 Paraproctus

0 , with lateral sclerites fused to valvifers; 1 , with free lateral sclerites; 2, simple, without lateral sclerites

68 Basal part of male sternum S8

0 , very narrow basally; 1 , quite wide, simply rounded; 2 , wider, short; 3 , widened, constricted before apex

69 Sternum S7

0 , emarginate; 1 , straight

70 Window in male sternum S8

0 , present; 1 , absent

71 Spiculum gastrale

0 , present (Fig. 162); 1, absent

72 Apex of female sternum S7

0 , simple; 1 , shallowly emarginate; 2 , deeply emarginate

\section{Phylogenetic analysis}

A total of 72 characters, as given in Table 2 were run unordered and unweighted. The minimum length trees were searched using computer program Hennig86 ver. 1.5 (Farris, 1988) using the Wagner parsimony analysis. The procedure of " $\mathrm{mh}^{*}$ " (multiple hennig) and "bb*" (branch breaking) were used in all analyses. The results obtained by this procedure are uncertain to be of minimal length, but the implicit enumeration was not used because the matrix was too extensive and the computer equipment unable to deliver the results in a reasonable time. Subsequently using the "xstep" command each character was weighted according to its fit to the tree in the preceding run. The 


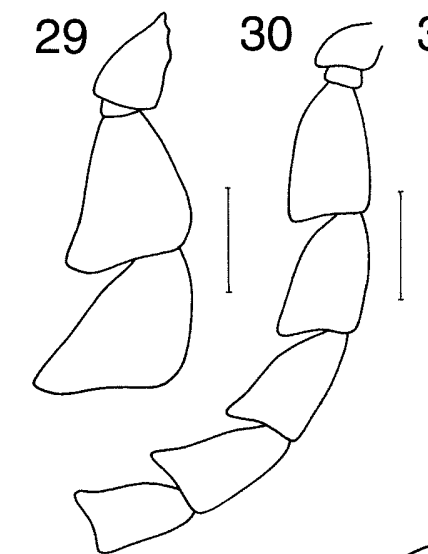

38

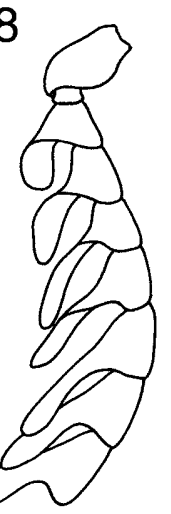

39<smiles>C1CC2CCCC(C1)C2</smiles><smiles>CCCC</smiles>

45

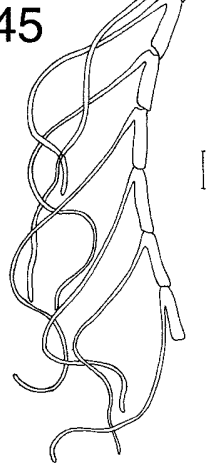

52

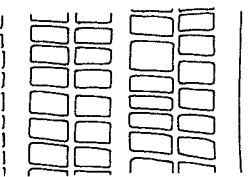

53

54

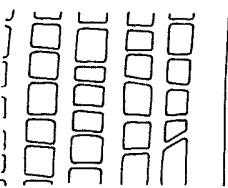

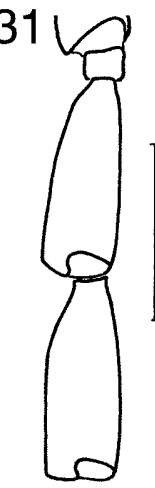

32

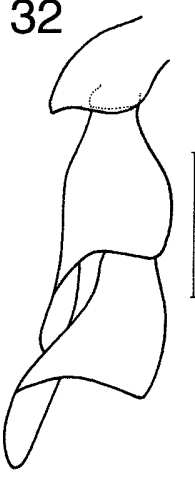

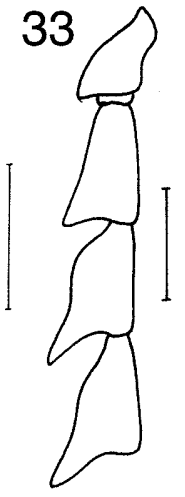

34

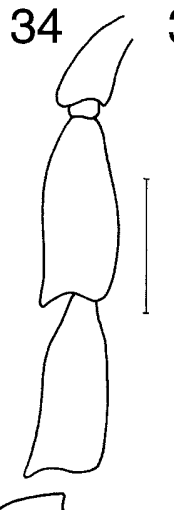

35

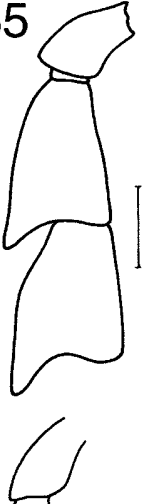

36
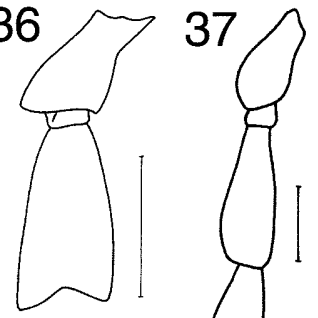

41

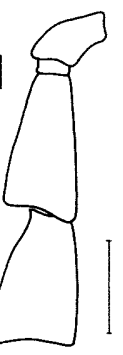

42
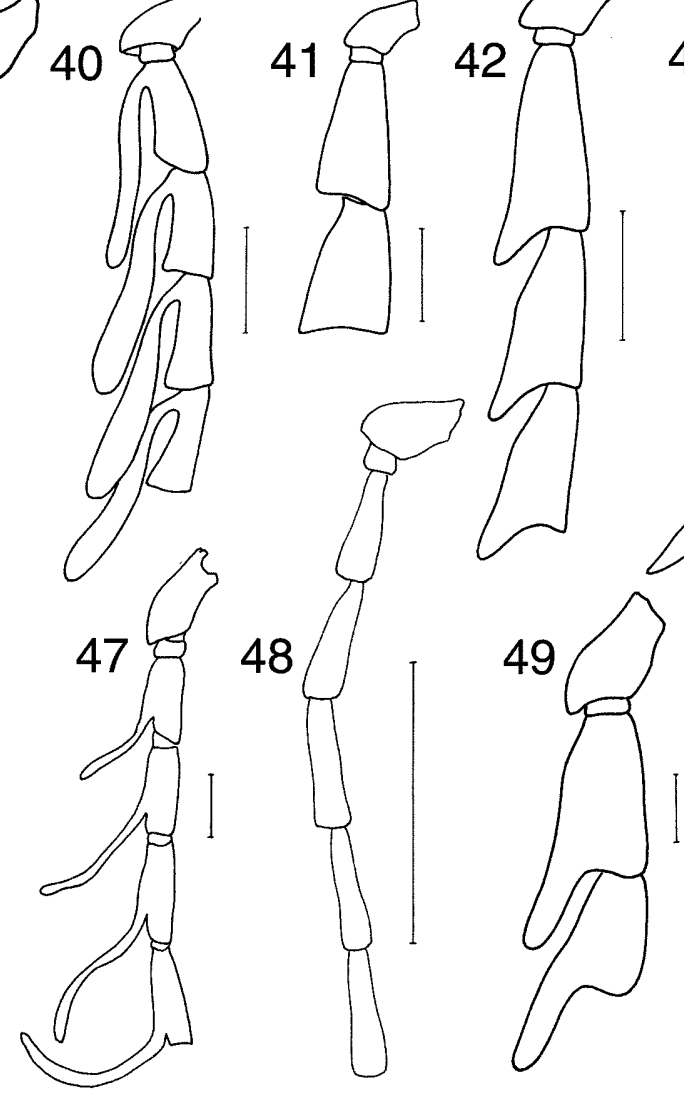

43
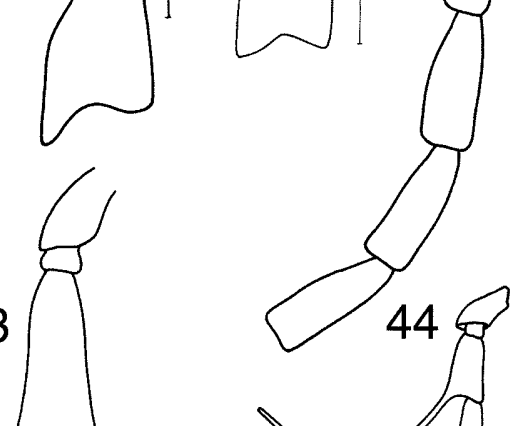

(1)
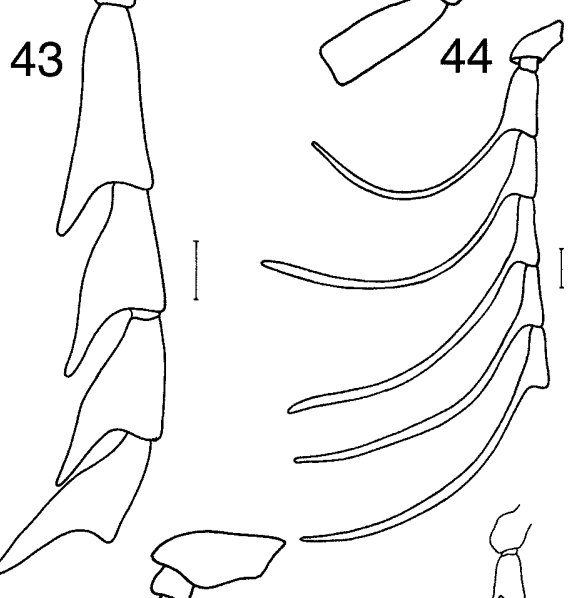

50

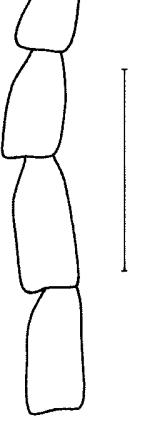

51
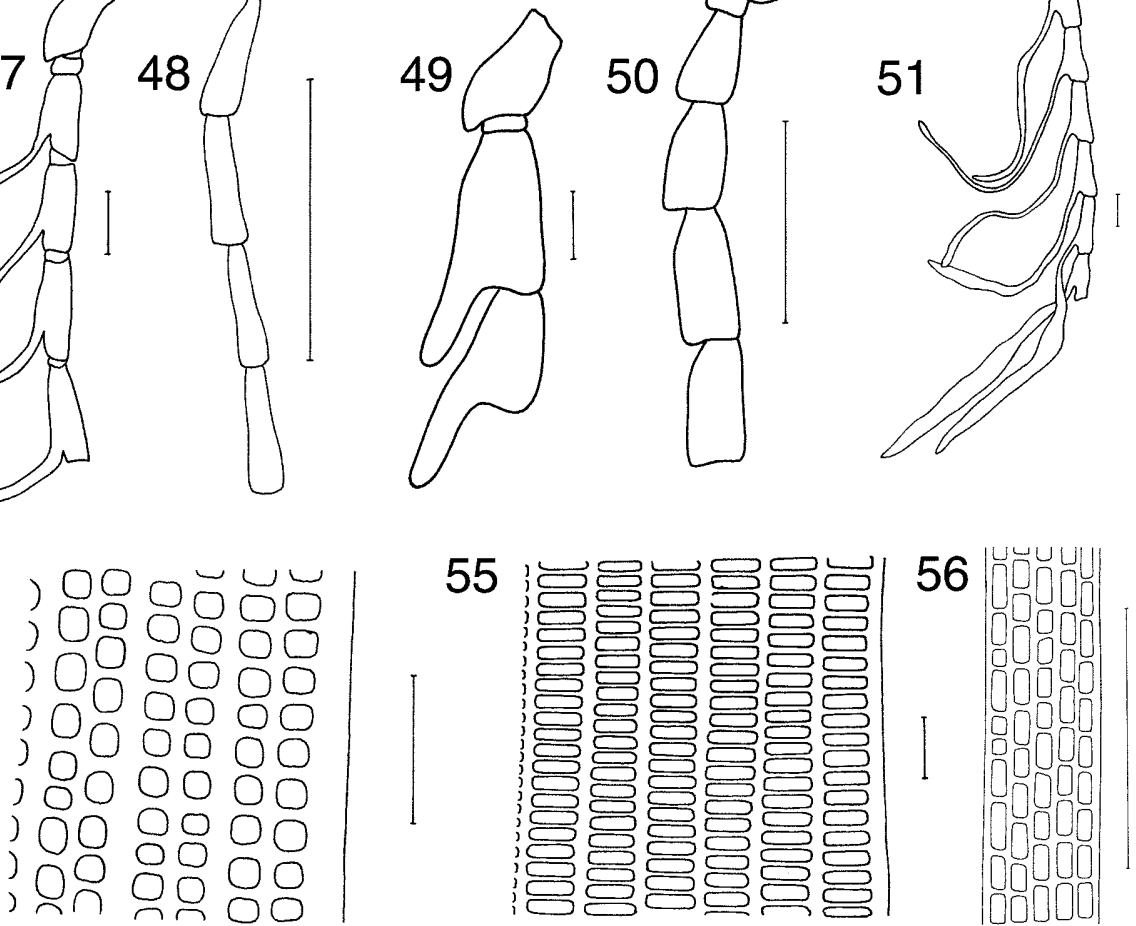

55

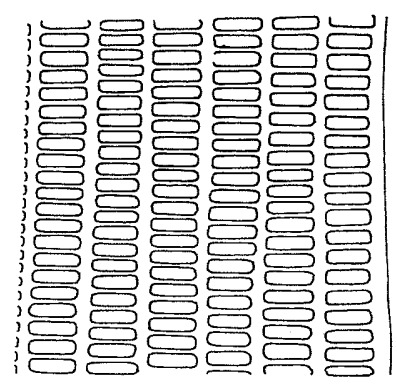

56

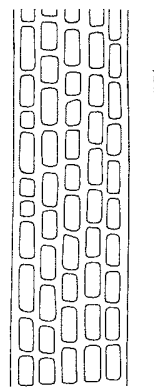

Figs 29-56: 29-51. Basal antennomeres. 29 - Conderis signicollis, male; 30 - Achras limbatus, male; 31 - Hemiconderis gracilis, male, ventral view; 32 - Diatrichalus salomonensis, male; 33 - Diatrichalus assimilis, male; 34 - Microtrichalus griseus, male; 35 Trichalus flavopictus, male; 36 - Metriorrhynchus mirabilis, female; 37 - Prometanoeus ochraceus, male; 38 - Cautires ratus, male; 39 - Caenioxylobanus ater, female; 40 - Metanoeus pallidus, male; 41 - Metriorrhynchus inaequalis, male; 42 - Porrostoma lateralis, male; 43 - Metriorrhynchoides helleri, male; 44 - Cladophorus elegantulus, male; 45 - Pseudodontocerus sp., male; 46 Pseudodontocerus pulcher, female; 47 - Pseudodontocerus sp., female; 48 - Malacolycus paululus, male; 49 - Porrostoma rhipidium, male; 50 - Mimoxylobanus reticulatus , male; 51 - Cladophorus sp., male; 52-56. Elytral reticulation. 52 - Porrostoma sp.; 53 - Pseudodontocerus pulcher; 54 - Pseudodontocerus sp.; 55 - Metriorrhynchoides sp.; 56 - Malacolycus paululus. Scales 0.5 mm. 
Dictyoptera

Calochromus

Lyponia

Pyropterus

Conderis

Xylobanellus

Diatrichalus

Enylus

Flabellotrich.

Schizotrichalus

Eniclases

Trichalus

Microtrichalus

Synchonnus

Achras

Hemiconderis

Wakarumbia

Bulenides

Caenioxylobanus

Cautires

Xylobanus

Broxylus

Prometanoeus

Tapromenoeus

Metanoeus

Stadenus

Metriorrhynchoid.

Porrostoma

Metriorrhynchus

Leptotrichalus

Lobatang

Cladophorus

Procautives

Cautiromimus

Kassemia

Ditua

Carathrix

Pseudodontocerus

000000001000000000000000000000000000000000000000000000000000000000000001 $00020001200000000010--00000-\ldots--0000000000000000000000000000100000000102$ $0001100010 \quad 00-0100010--00000001000100000 \quad 00000000000-011002000100000100 \quad 02$ $00010000100000000000 \quad 00000000100000000000 \quad 00000000000000000000000000000100$ $0110100010 \quad 00-00100001101000000 \quad 00010000010000000101 \quad 1000001000011000001002$ $0111100010 \quad 00-0010000110100002000010000010000000101 \quad 1000001000011000001002$ $02111001001110-10010 \quad 11210001-1 \quad 000101101000006000000101111100111101210101$ $001110011100100100101-010001002101111110000020-0000101121100111101220111$ 020310212100101100101121000101000111101000100000000101121100111110220101 $0203102121001001011011110001010002-1101000100000100101121100111110220101$ $00031021210010-10110 \quad 1--1000101000111101000100000100101121100111110220101$ 020310212100100100101121000101000201101000102000000101121100111110230100 000310212100100100101121000101000201101000102000000101121100111110220100 $0211100100 \quad 01100100001001000000 \quad 110101101001001000000101201100111100120110$ $0111102000 \quad 01100100001101001000110201101001001000000101201100111100120111$ $0211102000 \quad 01100100001101001000210201101000003010000101201100111100220111$ $0211102000 \quad 01100100001101001010110101111000004010000101201100111100230111$ $021110000100101101111111000000 \quad 000211102001001000000101101100111100120100$ $0211100000 \quad 0110110011 \quad 1111000020 \quad 0002111010 \quad 01001000000101101100111100110100$ $0111000001001011010-111110000000020110200100100000010110110011110012010-$ 0111000010 0010-101-0 1111100020 0002-11020 $0100100000010120110011110011010-$ $0111100000 \quad 00100101-01111100020000211101001001000000101101100111100210100$ 011100010100100101001111100000300001101001001000000101101100111100120100 011100010100100101001111100020300011101001001000000101101100111100120100 $021110010100111101001111100-00 \quad 1002111000-0002000000101201110131100220111$ $021400011101101101-01111-002001-0411100000010000000101101101111100220110$ $100412112100101101001111100200 \quad 000420000000010000000101101101111100120111$ $100412112100101101001111100200100420100000010000000101-0110111110022011$ $02101010010010-101001111110000 \quad 000210000000010000000101111100111100130110$ $02020210210010010010112100000100021110100001000000010111111012110--0111$ 020202102100100100101121000001000211111000010000000101111110121100130111 0214100000 $001-110100 \quad 1111100-00 \quad 0002111100 \quad 000051000001112111101111001301 \quad 10$ $021110000000101101001111100-30000211111010000100000111101110111100130100$ $011001000001101101001111110000000211111010000100000111-0110011110013011-$ $0111110010 \quad 01101101001111100021 \quad 1001111010 \quad 10002100000111201100111100221100$ $011001000100100101001111100000 \quad 0012111100 \quad 10002100000111201100111100130100$ $021001000100111111001111110000001-01101010002100000111201110111100120111$ $021011001011111111001111110000 \quad 0011011010 \quad 10002100000111101110111100120111$

weights were reassigned until the topology of the resultant trees did not change. The program Tree Gardener ver. 2.2 (Ramos, 1997) was used for matrix edition and control of Hennig86 program. The Clados ver. 1.9 program (Nixon, 1998) was used for mapping of characters on a tree and a program default setting "hom0" was applied. This setting indicates as homoplasious only those changes that are designated as of independent origin.

\section{Depositories}

Material was examined from the following institutions and collections: BMNH, Natural History Museum, London; BPBM, State Museum of Natural and Cultural History, Honolulu, Hawaii; DEIE, Deutsches Entomologisches Institut, Eberswalde; HNHM, Hungarian Natural History Museum, Budapest; MHNG, Muséum national d'histoire naturelle, Geneva; MHNP, Muséum national d'Histoire naturelle, Paris; MNHU, Museum für Naturkunde, Humboldt Universität, Berlin; MHNB, Museum d'Histoire naturelle, Brussels; MSNG, Museo civico di storia naturale, "Giacomo Doria", Genova; NHMB, Naturhistorisches Museum, Basel; NHMW, Naturhistorisches Museum, Vienna; RMNH, Natural History Museum, Leiden; SMNS, Staatliches Museum für Naturkunde, Stuttgart SMTD, Staatliches Museum für Tierkunde, Dresden; USNM, National Museum of Natural History, Washington, D.C.; ZMAN, Zoological Museum, Amsterdam; ZMPA, Instytut Zoologii PAN, Warsaw; LMBC, author's collection.

\section{PHYLOGENETIC ANALYSIS}

\section{Results}

When Calochromus, Lyponia, Dictyoptera, and Pyropterus were used to root cladograms, the analysis $\left(\mathrm{mh}^{*}\right.$, $\mathrm{bb}^{*}$ ) yielded three parsimonious trees, each with 261 steps, a $\mathrm{CI}=0.39$ and a $\mathrm{RI}=0.69$. The strict consensus tree derived from them was identical with one of the original trees and included a polytomy in Trichalina (Fig. 1), and therefore the length, CI and RI of these trees did not differ. When only one of the original outgroup taxa was designated as an outgroup, the topology of the tree did not change. The mapping of characters is given in table 3 , and the number of clades in Fig. 1.

Further, successive weighting was applied to the matrix after $\mathrm{mh}^{*}$ and bb* (again with Calochromus, Lyponia, Dictyoptera and Pyropterus as outgroups). Two trees with length 651 , a CI $=69$ and a $\mathrm{RI}=86$ were obtained. These trees differed in the position of Xylobanus, either being a sister-group of Cautires or Broxylus. The consensus tree was slightly longer (length 653) and had identical indexes. The strict consensus tree differs in that it has a polytomy in the Cautires clade.

\section{Discussion}

The present analysis is the first attempt to investigate the phylogeny of the Metriorrhynchinae using a cladistic approach. The only classification of Lycidae (Bocak \& Bocakova, 1990a) is not based on phylogenetic principles but on the need to diagnose supergeneric taxa for a comparative morphology of the major groups of Lycidae, and their identification. Nevertheless, the monophyly of the Metrirrhynchinae as understood by Bocak \& Bocakova (1990a), as well as their constitutive tribes and subtribes is supported by the present phylogenetic analysis. The 

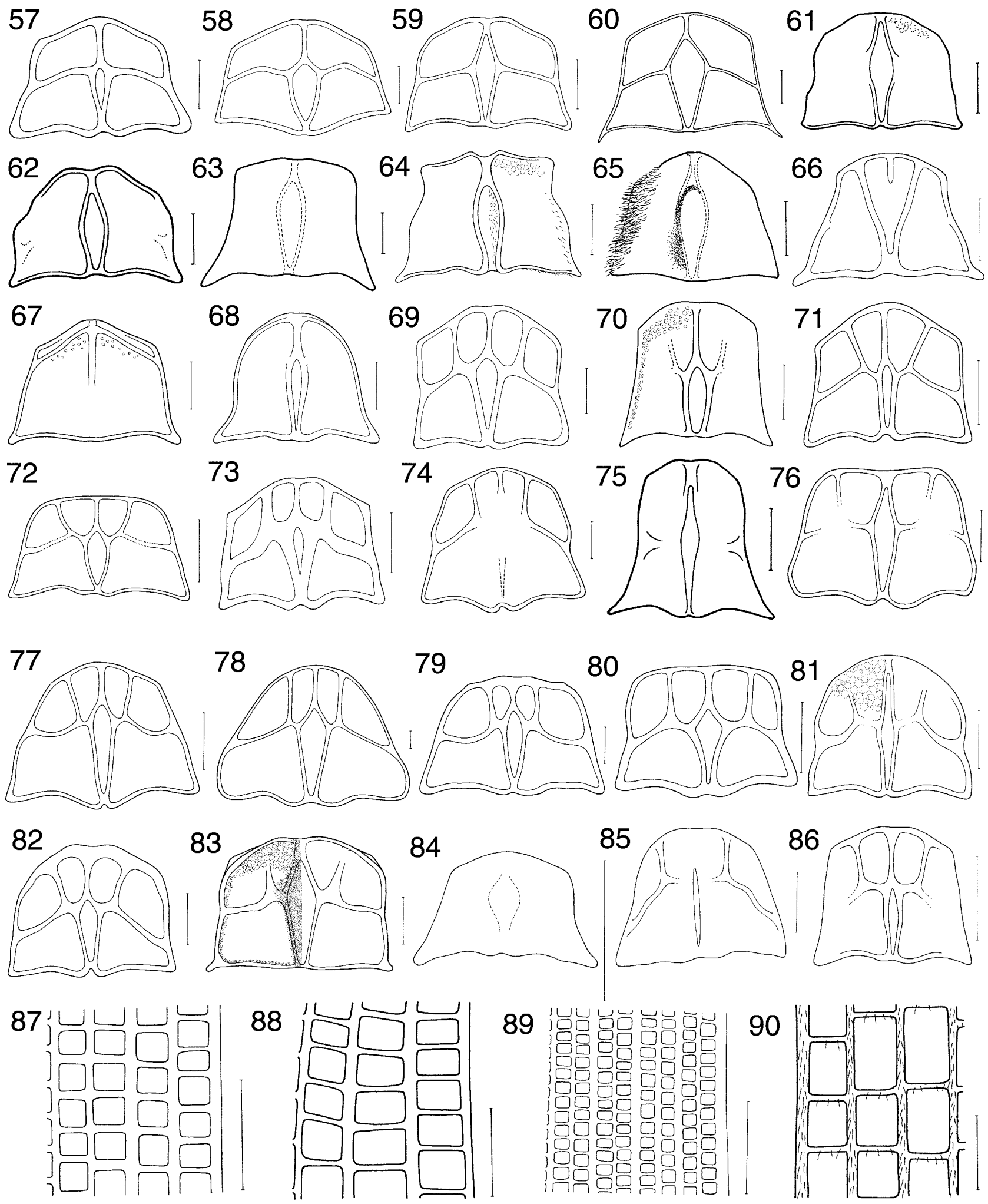

Figs 57-90: 57-86. Pronotum. 57 - Xylobanellus erythropterus; 58 - Conderis signicollis; 59 - Synchonnus clientulus; 60 - Hemiconderis explicatus; 61 - Enylus amplus; 62 -Diatrichalus salomonensis; 63 - Microtrichalus acutangulus; 64 - Microtrichalus patricius; 65 - Flabellotrichalus bilineatus; 66 - Eniclases nigriceps; 67 - Caenioxylobanus ater; 68 - Bulenides inapicalis; 69 Xylobanus benignus; 70 - Broxylus fenestratus; 71 - Cautires ratus; 72 - Prometaneus ochraceus; 73 - Metanoeus dispar; 74 Metriorrhynchus thoracicus; 75 - Leptotrichalus accuratus; 76 - Stadenus puncticollis; 77 - Porrostoma lateralis; 78 - Metriorrhynchoides helleri; 79 - Cladophorus praecipuus; 80 - Ditua deplanata; 81 - Cautiromimus reticulatus; 82 - Procautires toxopei; 83 - Pseododontocerus pulcher; 84 - Malacolycus paululus; 85 - Dilolycus lamellatus; 86 - Mimoxylobanus reticulatus; 87-90. Elytral reticulation. 87 - Xylobanellus erythropterus; 88 - Caenioxylobanus ater; 89 - Cautires sinensis; 90 - Broxylus fenestratus. Scales $0.5 \mathrm{~mm}$. 
TABLE 3. Synapomorphies and homoplastic changes listed by nodes for the cladogram in Fig. 1.

\begin{tabular}{|c|c|c|}
\hline Nodes & Synapomorphies & Homoplastic changes \\
\hline 1 Metriorrhynchinae & $3.1,13.1,16.1,21.1,24.1,57.1$ & 34.1 \\
\hline 2 Conderini & $40.1,48.1,50.1,51.1$ & $2.1,69.1$ \\
\hline 3 Metriorrhynchini & $\begin{array}{l}2.2,9.0,36.1,37.1,39.1,52.1 \\
58.1,63.1,64.1,68.2\end{array}$ & $\begin{array}{l}54.1,55.1,61.1,67.1 \\
70.1,71.1,72.1\end{array}$ \\
\hline 4 Hemiconderina & - & $12.1,31.1,32.1,45.1,55.2$ \\
\hline 5 & 27.1 & 7.2 \\
\hline 6 & 47.1 & 67.2 \\
\hline 7 & - & $10.1,35.1$ \\
\hline 8 Trichalina & $28.1,56.2$ & $8.1,19.1,67.2$ \\
\hline 9 & - & $23.2,30.1,71.0$ \\
\hline 10 & $4.3,43.1,65.1$ & $3.0,7.2,9.2$ \\
\hline 11 & - & $34.2,35.0,45.2,72.0$ \\
\hline 12 & 49.1 & $18.1,23.1$ \\
\hline 13 Metriorrhynchina & - & $23.1,34.2$ \\
\hline 14 & - & $4.0,7.1,44.1,56.1,68.3$ \\
\hline 15 & 62.2 & $3.0,4.2,5.0,6.2,9.2,19.1,23.2,30.1,59.1$ \\
\hline 16 & - & $15.1,18.1,25.1$ \\
\hline 17 & - & $8.1,31.1,39.0,67.2$ \\
\hline 18 Porrostoma-group & $28.2,34.4,60.1$ & $4.4,44.1$ \\
\hline 19 & $1.1,35.2$ & $2.0,3.0,6.2,7.1,9.2,36.0$ \\
\hline 20 & - & $71.0,72.0$ \\
\hline 21 & - & $42.1,45.1$ \\
\hline 22 Bulenides-group & 20.1 & $19.1,25.0$ \\
\hline 23 Cautires-group & - & $2.1,5.0$ \\
\hline 24 & - & 15 \\
\hline 25 & 31.3 & $8.1,34.0$ \\
\hline 26 & - & $10.0,29.2,68.1$ \\
\hline 27 Ditua-group & $41.1,46.1,53.1$ & $10.0,55.2$ \\
\hline 28 & - & $6.1,34.1,45.2$ \\
\hline 29 & 17.1 & $4.0,14.1,26.1,33.1,35.0,59.1,71.1,72.1$ \\
\hline 30 & - & $38.1,68.3$ \\
\hline 31 & - & $2.1,4.0,5.0,6.1$ \\
\hline 32 & - & 59.1 \\
\hline
\end{tabular}

monophyly of the Cladophorini as defined by Kleine (1933) and elsewhere was rejected by both hypotheses (Figs 1, 2).

The monophyly of the Metriorrhynchinae is supported by several synapomorphic characters: transverse gula (Fig. 11), considerably compressed antennae, antennomere 2 much shorter than antennomere 3 (Figs 29-51), unconstricted base of median areola (Figs 57-86), median areola connected to frontal margin of the pronotum by a keel (Figs 57-60, 62-86), symmetrical bulges at base of pronotum absent, circular phallobase (Figs 91-132). The shape of the phallobase is very characteristic and unlike that of other Lycidae. In addition, the shape of the pronotal carinae is very characteristic and only specimens of Enylus is these an indistinct frontal keel, but even in such cases the general appearance of the pronotum is different. The very short antennomere 2 is possibly a synapomorphic character state, although Ateliinae have a very short antennomere 2 as have several Leptolycinae. Both groups differ substantially in the shape of their cranium, male genitalia and Ateliinae have pobably neotenous females (Bocak \& Matsuda, in press). These groups are unrelated to the Metriorrhynchinae, therefore an independent origin of these character states in the Metriorrhynchinae is suggested.

The Conderini, according to the present phylogenetic hypothesis (Figs 1,2), have a basal placement within the Metriorrhynchinae. That the phallus has a laterally compressed apical part, and a hook-like base, and there are processes on the phallobase support their monophyly. A11 these characters are unique within the Lycidae. Additionally, the shape of the pronotal carinae is very characteristic in most species (Figs 57, 58), but the shape of the carinae is not the same in all specimens of some species and therefore was not coded in the matrix. Conderini share several symplesiomorphic character states with the 

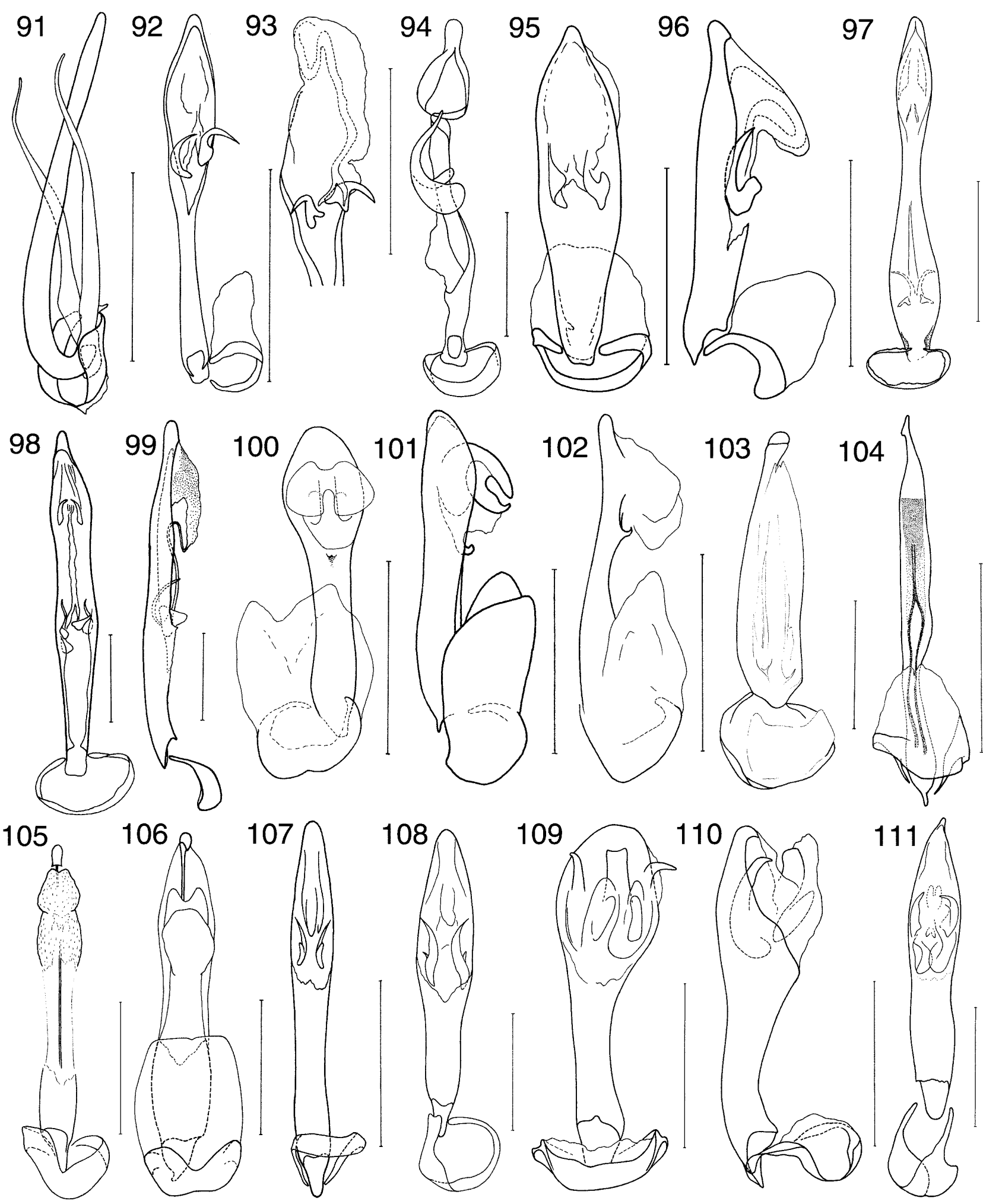

Figs 91-111: Male genitalia. 91 - Conderis signicollis; 92- 93 - Synchonnus clientulus; 94 - Wakarumbia angustior; $95-96$ Achras limbatus; 97 - Enylus segregatus; 98 - 99-Enylus amplus; 100 -101 - Diatrichalus assimilis; 102 - Diatrichalus sp.; 103 Microtrichalus bicoloripes; 104 - Flabellotrichalus notatithorax; 105 - Schizotrichalus nigrescens; 106 - Eniclases apertus; 107 Bulenides sp.; 108 - Cautires sinensis; 109 -110 - Xylobanus costifer; 111 - Broxylus fenestratus. Scales $0.5 \mathrm{~mm}$.

Erotinae. The female genitalia have a very similar shape and the basal part of coxites is streghthened, male genitalia have long parameres, and a completely membranous internal sac.
The monophyly of the clade forming the tribe Metriorrhynchini is supported by the regularly exposed, sclerotized or at least pigmented internal sac (Figs 92-132), the flat, apparent, unpaired vaginal gland (e.g. Figs 

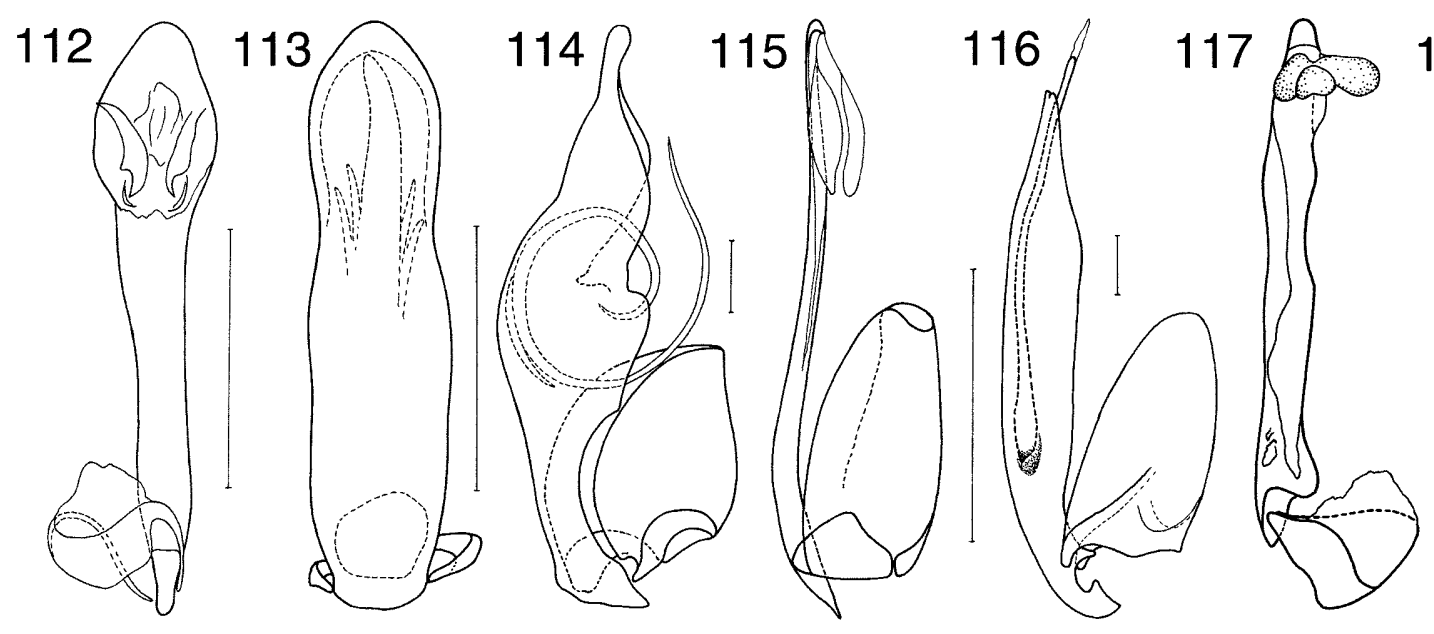

118
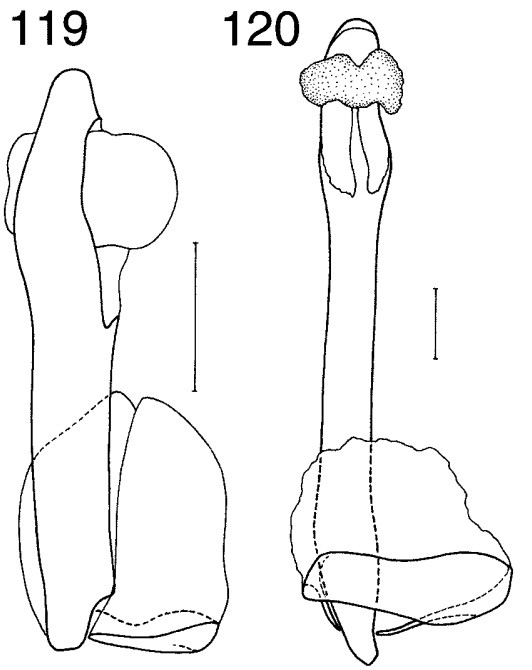

121
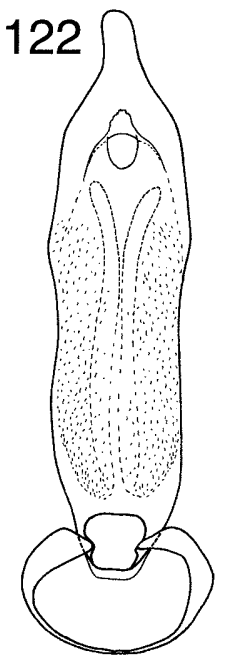

123

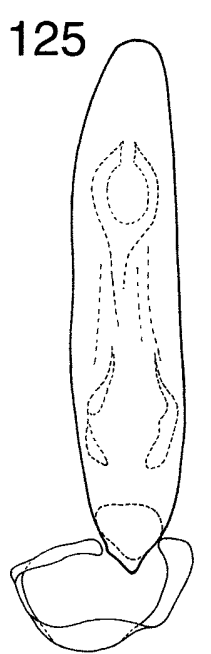

126
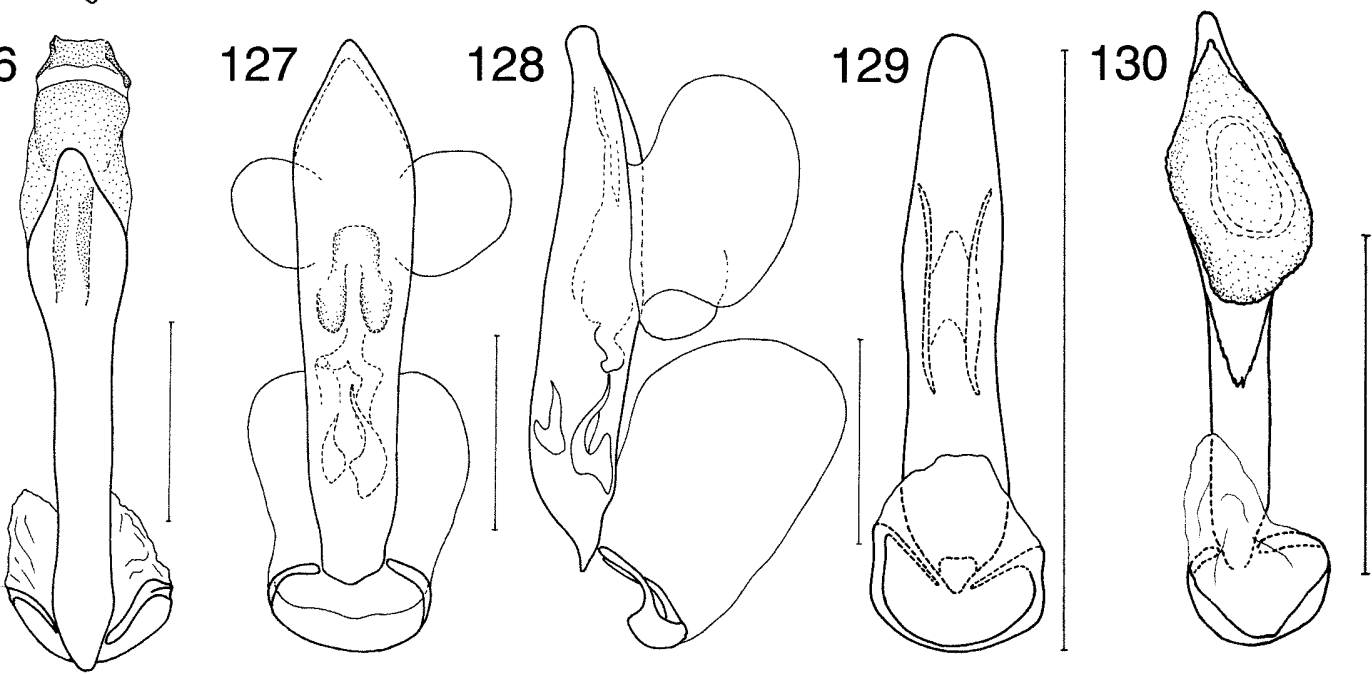

Figs 112-130: Male genitalia. 112 - Prometanoeus ochraceus; 113 - Metanoeus sp.; 114 - Metriorrhynchus thoracicus; 115 Leptotrichalus adolescens; 116 - Lobatang dubitabilis; 117 -118 - Stadenus triareolatus; 119 - Porrostoma rufipennis; 120 - Metriorrhynchoides helleri; 121 - Cladophorus sp.; 122-123 - Cautiromimus reticulatus; 124 - Cladophorinus cyanescens; 125 - Ditua deplanata; 126 - Procautires sp.; 127-128 - Pseudodontocerus sp.; 129 - Malacolycus paululus; 130 - Xylobanomorphus transformis. Scales $0.5 \mathrm{~mm}$.

143-146), lateral vaginal glands with a narrow, usually slightly sclerotized base (e. g. Figs 143-146), simple basal margin to coxites (Figs 134-140), mesoscutellum with long lateral processes, and short alacrista. The complete set of synapomorphic character states is given in
Tab. 3, and the characters not mentioned here have undergone multiple reversions. The absence of parameres are hypothesised to be a homoplasy, because this character state has evolved independently in Lyponia (Platerodinae, char. 54) and is known also in the Platerodini, which were 
not included as an outgroup in the analysis. Metriorrhynchini differ in this character from all similar Lycidae. However, the loss of parameres has occurred independently in other groups.

The tribe Metriorrhynchini is formed by three subtribes: Trichalina, Hemiconderina and Metrirrhynchina. Their relationship is unresolved. When no successive weighting was applied, the Trichalina had a basal position as a sister-group of the remaining Metriorrhynchini, and the Hemiconderina were the next basal clade. After successive weighting the relative position of these subtribes changed (Figs 1, 2). But in all analyses these clades remained stable. Unfortunately the larvae of these groups are unknown and I have not found a character to corroborate the hypotheses. Both hypotheses can be interpreted in the same way in the formal classification.

Kleine $(1928,1933)$ defined the Trichalina as a group of Metriorrhynchinae genera with a short elytral primary costa 1. Bocak (1998b) showed that the shortened costa 1 evolved several times in the Metriorrhynchinae and therefore restricted Trichalina to the terminal clade Trichalus + Microtrichalus + Flabellotrichalus + Schizotrichalus + Eniclases and provisionally classified Enylus and Diatrichalus as incertae sedis in the Metriorrhynchini. The present analysis placed Enylus and Diatrichalus basally in this clade because of two synapomorphic character states: tubercles on the lateral margin of the pronotum (Figs 61-66) and the shape of the basal part of phallus (Figs $104,106)$. The tubercles may or may not be distinct in individual specimens but are regularly present, and together with the characteristically elevated lateral margins give the uniform pronotal appearance of the Trichalina. Considering the topology of the trees produced by the present analysis (Figs 1,2), Enylus and Diatrichalus must be classified in the Trichalina.

The Hemiconderina as proposed by Bocak \& Bocakova (1990a) was monotypic. Later, Bocak (1999b) described Wakarumbia from Sulawesi put it in the Hemiconderina. This was supported by the present analysis and additionally the Australian Achras was added to the terminal clade which is characterised by straight slender costae (char. 27). In both cladograms (Figs 1,2) Synchonmus is a basal member of the Hemiconderina. Although genera classified in the Hemiconderina have many similar characters, it can not be defined as a monophyletic group, as the Hemiconderina clade has no autapomorphic character state.

That the Metriorrhynchina is monophylic is not well founded, as I have not found any synapomorphic character state to support the cladistic definition. In addition, the relationships between the individual clades within the Metriorrhynchina remain obscure.

Most members of this clade have a complex pattern of pronotal carinae forming four areoles on the frontal margin of the pronotum (i. e., frontolateral costae are present on the pronotum, character 18). This character is useful for identifying most Metriorrhynchina. On the cladogram in Fig. 1 the Metriorrhynchina without basal clade Bulenides and Caenioxylobanus share the state
18.1, after successive weighting (Fig. 2) the state 18.1 is not shared by the basal Metriorrhynchus+Lobatang + Leptotrichalus clade. Additionally, this character is a homoplasy as it is a similar arrangement of carinae in Schizotrichalus and Eniclases (Fig. 66). The arrangement of carinae in Eniclases is quite different from that of most Metriorrhynchina - only two diverging keels are present (Fig. 66). Schizotrichalus has similar longitudinal carinae but its median frontal carina is forked apically and connected with longitudinal carinae. Consequently, three carinae are attached to the frontal pronotal margin. Having no evidence to the contrary, both situations were scored as an identical character state. Further evidence will be needed to support or refute the Metriorrhynchina. As few larvae of the Metriorrhynchina have been described (Bocak \& Matsuda, in press) they will not help to solve this ambiguity. The larvae of most known Cautires and Xylobanus are very similar and they share some characters with Metriorrhynchus. Porrostoma differs in having characteristic processes on the hind margins of its terga. Most of them share with Xylobanellus terga that are divided in two parts by a membranous line.

Only two constitutive clades give robust support to both cladograms (Figs 1,2): the Ditua group formed by almost exclusively Papuan genera and the Porrostoma group with a restricted Austro-Papuan distribution. The clade Bulenides + Caenioxylobanus is either a basal group (Fig. 1) with the Cautires clade as the next clade, or they are a basal group within the Cautires clade (Fig. 2).

The position of Metanoeus is variable and it is attached as a basal member either to the Porrostoma or Ditua clade. In any case, Metanoeus, has an Oriental distribution, and is not related to the Afro-Oriental clade ( $\mathrm{Cau}$ tires, Bulenides, Prometanoeus, etc.). Some characters present only in some members of these genera could not be coded in the matrix: several Metriorrhynchus species share with Metanoeus very obtuse, indistinct pronotal carinae and both have shorter (Metriorrhynchus) to vestigial (Metanoeus) valvifers. Further evidence is needed to clarify the position of Metanoeus.

\section{Zoogeography}

Unfortunately, the very fragmentary knowledge of Lycidae at the alpha taxonomic level and consequently the doubtful information on generic distribution limit the following discussion. I have used unpublished information gathered by studying collections in the above institutions. The data in the lycid catalogue (Kleine, 1933) are inapplicable. The typological species concept applied to most genera by Kleine and the problems originating from Pic's confused work means that these data has to be confirmed by studying the original type material. Information on the distribution of genera is given in the systematic part.

On the other hand, Lycidae appear incapable of crossing natural barriers such as sea straits or deserts. Lycidae are often limited to humid mountain habitats and when these mountains are isolated, Lycidae easily speciate. Unlike many other groups, there are very few lycid species with a very wide range. The few widely distrib- 


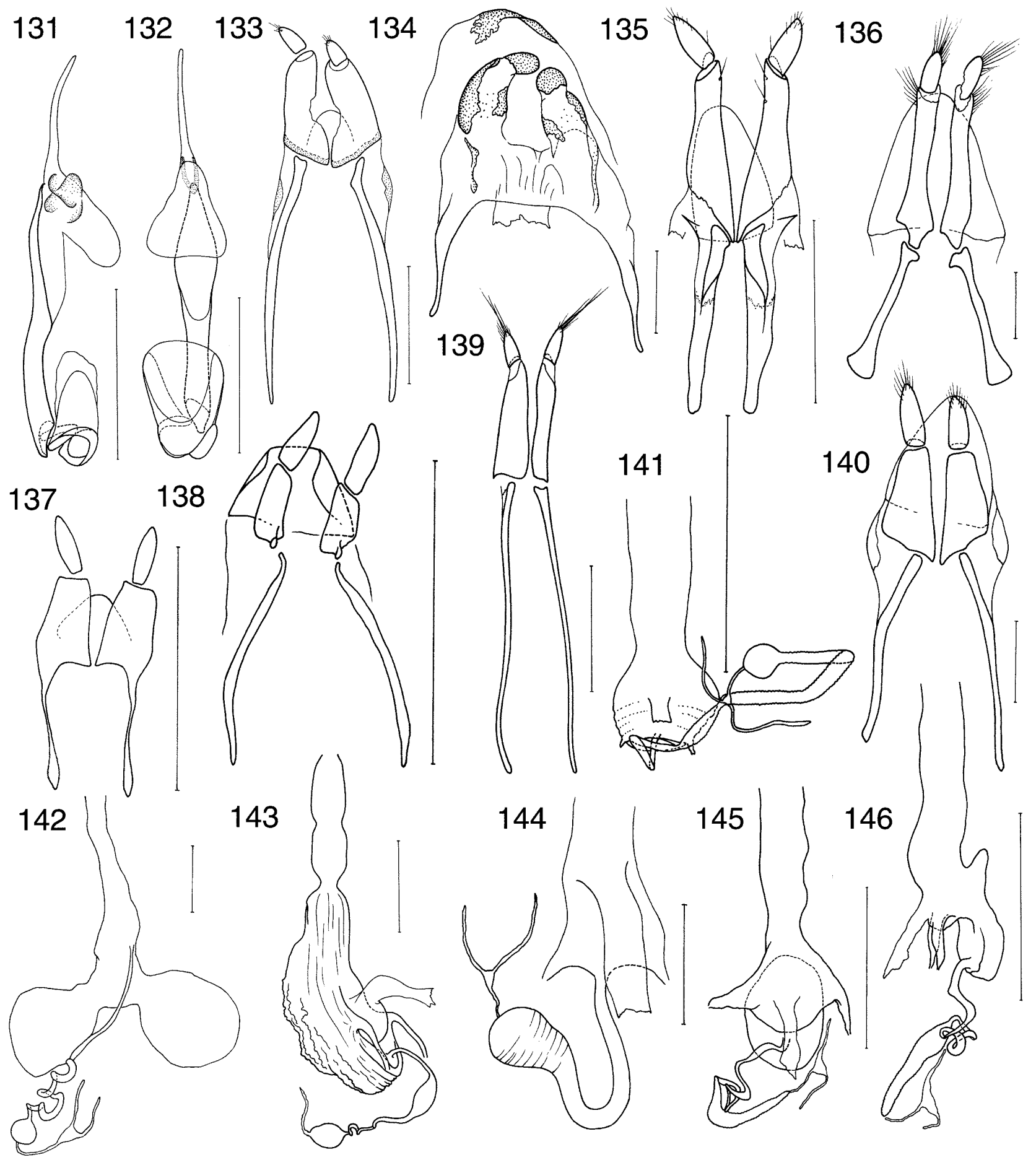

Figs 131-146: 131-132. Male genitalia, Mimoxylobanus reticulatus; 133-140. Ovipositor. 133 - Xylobanellus erythropterus; 134 - Metriorrhynchus sp.; 135 - Caenioxylobanus ater; 136 - Metriorrhynchoides sp.; 137 - Strophicus nigellus; 138 - Synchonnus appositus; 139 - Pseudodontocerus pulcher; 140 - Cladophorus sp.; 141-142. Female genitalia. 141 - Caenioxylobanus ater; 142 Xylobanellus erythropterus; 143 - Pseudodontocerus pulcher; 144 - Cladophorus sp.; 145-146 - Synchonnus appositus. Scales 0.5 $\mathrm{mm}$.

uted species are usually from lowlands and in this case the size of range is not impressive. I know only of one species that occurs in two zoogeographical regions.

The substantial part of the Metriorrhynchinae is an east Gondwanan element (distribution of Conderini is discussed further) with some representatives distributed in East Asia and a single species widely distributed from
Russian Far East through Siberia to Belarussia and Poland (Fig. 3). The highest species and generic diversity occurs in the humid tropics of the Old World, but the generic species diversity is low in the Afrotropical Region. There are also substantial differences in the contribution of Metriorrhynchinae to the total representation of Lycidae in the zoogeographic regions. 
The striking observation is that Conderini as a basal group within the Metriorrhynchinae have the distribution similar to Erotinae, although they are not recorded from the Nearctic Region. Most species are known from the south-eastern part of the Palaearctic Region and the northern part of the Oriental region, fewer species occur distributed in the north-eastern part of the Palaearctic. Unlike the Erotinae they are not known from the Afrotropical and Nearctic Regions (Fig. 3).

The range of Metriorrhynchini is limited to the Afrotropical, Oriental, Australian and eastern part of Palaearctic Regions. It seems reasonable to assume that the Metriorrhynchini dispersed to the Palaearctic Region after they evolved somewhere on the Gondwana continent. There are no endemic genera in the Palaearctic, and generally both the species and generic diversity of Palaearctic fauna are extremely low and decreases with the distance from the Oriental Region. Additionally, the Metriorrhynchinae form usually a small fragment of the Lycidae collected in the Palaearctic Region, unlike in the Oriental Region. The distribution of the Metriorrhynchini is given in Fig. 3 .

Another important observation is that within the Metriorrhynchinae the two Australian lineages, Hemiconderina and Trichalina, have a basal position and that the diversity of Australian fauna is much higher than Afrotropical one. The Hemiconderina are endemic to the Australian Region (Fig. 5) and within the subtribe the basal lineage represented by Synchonnus is restricted to continental Australia as well as Achras, which also has several plesiomorphic characters. The remaining genera of Hemiconderina are recorded from New Guinea and the Indonesian Archipelago east of the Wallace line. Both, Hemiconderis, known from New Guinea and the Yapen Island, and Wakarumbia, from Sulawesi and the Buton Island, have undergone considerable speciation. At present, 23 Wakarumbia species are recorded from Sulawesi. Although, they show three different colour patterns, the substantial differences are in the male genitalia. Considering the tectonic history of Sulawesi and the limited range of Wakarumbia, we can presume that a part of Sulawesi of Australian origin or a part having contact with some part forming today New Guinea brought the ancestor of Wakarumbia to Sulawesi. I have not found any group of species restricted to one part of an island (Bocak, 1999b, 2000c, 2001b), therefore the simultaneous speciation on various mountain ranges of widespread lowland species is possible.

The Trichalina are the other basal group of presumably Australian origin. All genera constituting the Trichalina are known from the Australian Region, only some of them, Diatrichalus and Microtrichalus are present also in the Oriental Region (Fig. 5). The highest diversity is generally found in tropical parts of the Australian Region. After the revision of the Papuan fauna almost forty Diatrichalus species are recorded from the Australian Region (Bocak, 2001a), and further species can be expected from Australia. On the other hand, only five Diatrichalus species were recently reported from the Phil- ippines (Bocak, 2000a) and only one species from the Asian continent and the Great Sundas. The distribution of Microtrichalus is similar. Although its range reaches further to the north and recently one species was found in southern Yunnan and northern Laos, the diversity of the Oriental fauna is very low and the number of species decreases gradually from the Wallace line to the northwest. Congruent with patterns found in other groups and the tectonic history, Microtrichalus is rich in species in the Philippines (Bocak, 1998d).

The range of Metriorrhynchina is almost coincident with that of the Metriorrhynchinae (Fig. 3). The Palaearctic fauna of Metriorrhynchina is poor, both in number of species and genera. Only Cautires and Xylobanus are reported from China, Japan and the Russian Far East. Metriorrhynchina are quite rare in the Palaearctic Region and form a small part of the Palaearctic lycid fauna considering the number of species. Dispersal from the south offers a possible explanation for the present distribution of Metriorrhynchina in the Palaearctic Region.

The Afrotropical fauna of Metriorrhynchina has not yet been revised and according to Kleine (1933) 192 species are reported from the Afrotropical Region. These species are classified in genera Cladophorus, Cautires, Procautires, Caenioxylobanus, and Xylobanus. I have studied available material in Pic's and Kleine's collections and I found that the Afrotropical species placed in Cladophorus and Procautires are not congeneric with Australian representatives of these genera and should be placed in Cautires. Afrotropical species of Stadenus were transferred to the Erotinae (Bocak \& Bocakova, 1992). Therefore, only genera Cautires (about 150 species), Xylobanus (about 40 species), and Caenioxylobanus (2 species) are now confirmed for the Afrotropical Region. The Afrotropical fauna seems species rich, but multiple synonyms can be expected as Pic often described common species several times. Caenioxylobanus reported from Madagascar is the only genus endemic to the region.

The Afrotropical and Indian faunas of Metriorrhynchina are similar regarding the representation of genera. Cautires, Xylobanus, and Prometaneus are the only genera occuring west of the low Brahmaputra River, and Prometanoeus is the only genus endemic to the western part of the Oriental Region. Cautires is a widely distributed genus known from West Africa to the Philippines (Fig. 4) and Japan. Xylobanus has a similar distribution, but unlike Cautires, Xylobanus crosses the Wallace line to the east. This genus has not yet been revised and the real relationship of the Australian representatives is unknown.

Metriorrhynchina from the eastern part of the Oriental Region are more diverse. In addition to Cautires and Xylobanus, two endemic genera are common in South East Asia - Metanoeus and Bulenides. Both do not cross the Wallace line (Fig. 4). Metriorrhynchus is the only genus in the Metriorrhynchina which has its centre of distribution in the Australian Region and reaches continental Asia. Although this genus is reported from India (Kleine, 

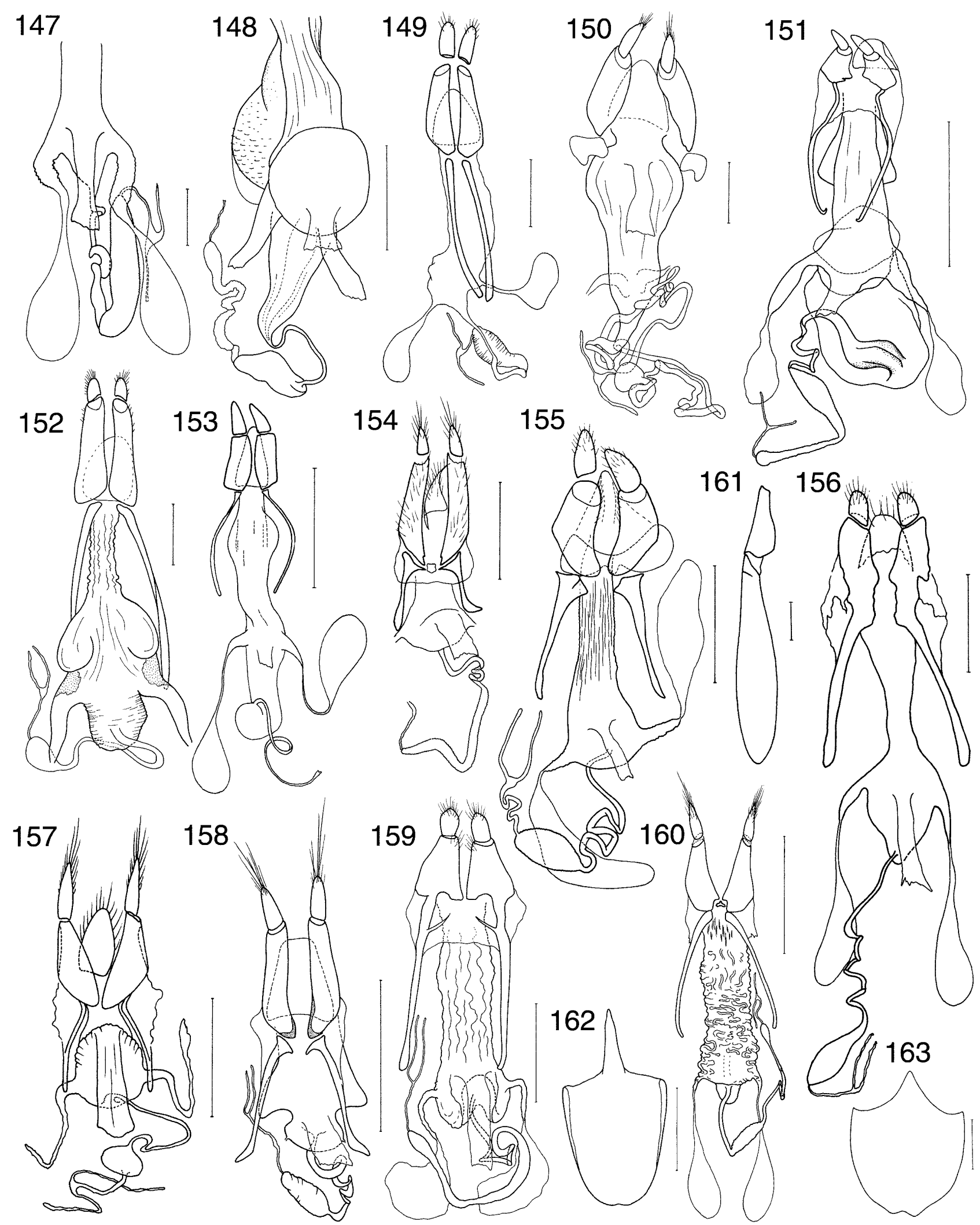

Figs 147-163: 147-160. Female genitalia. 147 - Metriorrhynchoides sp.; 148 - Metriorrhynchus mirabilis; 149 - Cautires sp.; 150 - Metanoeus sp.; 151 - Achras limbatus; 152 - Pseudodontocerus sp.; 153 - Wakarumbia gracilis; 154 - Xylobanus costifer; 155 - Bulenides obsoletus; 156 - Stadenus puncticollis; 157 - Leptotrichalus accomodatus; 158 - Broxylus fenestratus; 159 - Stadenus triareolatus; 160 - Cautiromimus reticulatus. 161 - trochanter and femur. Pseudodontocerus pulcher; 162-163. Female sternum A7. 162 - Procautires sp.; 163 - Cautires sp. Scales $0.5 \mathrm{~mm}$. 
1933), it was not found in collections from localities west of Burma.

There are several endemic lineages of Metriorrhynchina in the Australian Region: Pseudodontocerus, Stadenus, Ditua, Cladophorus, Cautiromimus, Broxylus, Kassemia, Porrostoma, and Metriorrhynchoides. The ranges of these genera extend to the west in various degrees (Fig. 6). Metriorrhynchus and Lobatang have most of their representatives in the Australian Region but a very small proportion of them cross the Wallace line onto the Asian continent (Metriorrhynchus) or to the Philippines (Lobatang). The distribution of Leptotrichalus is a bit different. Most species of Leptotrichalus are reported from the Philippines, several from Sulawesi, the Lesser Sundas, Java, Sumatra and Borneo, and several from the Asian continent, only one of which occurs beyond the Isthmus of Kra (Bocak, 2000b). Recently, several undescribed species were collected in Halmahera. This supports the conclusion about the relationship between Lobatang and Leptotrichalus inferred from morphological data in phylogenetic analysis. Lobatang, is a closely related genus known from the Papuan Subregion, Wallacea, and the Philippines. Most species are known from the eastern part of the region. Dispersal followed by speciation of an ancestor inhabiting islands north of Australia possibly lead to the present distribution and species richness of Leptotrichalus.

Two clades are restricted to the Australian Region. The clade Porrostoma, Stadenus and Metriorrhynchoides is the most common group in Australia with few species known from New Guinea. The Ditua clade (node 27, Fig. 1) is recorded mainly from New Guinea and adjacent islands. Few species occur in Australia. Metanoeus has an ambiguous position in the present analysis and is the only genus endemic to the Oriental Region, but related to clades whose centre of distribution is the Australian Region.

There are substantial differences in the relative representation of Metriorrhynchinae within the Lycidae. Metriorrhynchinae are relatively poorly represented in Afrotropical and Palaearctic Regions, where they usually form 10-20 per cent of collected specimens. They are more common in humid areas of South East Asia where they make up slightly over 50 per cent of the specimens. Their relative abundance increases to the east. East of the Wallace line the Lycidae are almost exclusively represented by the Metriorrhynchinae. The Metriorrhynchinae form 95 per cent of the specimens collected in New Guinea and a substantial part of the Australian lycid fauna. Metriorrhynchinae form 90 per cent of the lycid species recorded from Australia.

\section{Conclusion}

A. All ingroup terminal taxa form a monophyletic group characterised by the presence of a circular phallobase (Figs 91-132) and an antennomere 2 much shorter than antennomere 3 (Figs 29-51). Further apomorphic character states of Metriorrhynchinae are given in Table 3.

B. The present analysis supports the tribes Conderini and Metriorrhynchini. Three subtribes, Hemiconderina and
Trichalina with a basal placement, form the Metriorrhynchini. The Hemiconderina concept is redefined. The genera Diatrichalus and Enylus are returned to the Trichalina. The resulting cladograms varied but some clusters within the Metriorrhynchina were relatively robust (Ditua clade, Porrostoma clade and Cautires clade).

C. The distribution of clades was discussed. Conderini are restricted to East and South East Asia, Metriorrhynchini are considered to be an East Gondwanan element with only a few species reaching northern East Asia. All these species are members of widespread genera known from the Afrotropical and Oriental regions. All major clades classified as subtribes of Metriorrhynchina are either exclusively Australian or at least have most of their endemic taxa in the Austro-Papuan Region.

D. The cladistic analysis showed that characters used for a long time to define genera (presence and/or absence of elytral secondary costae, shortened primary elytral costae, and serrate of flabellate antennae) evolved several times in the Metriorrhynchinae.

This study aimed to establish phylogenetic relationship between the genera of Metriorrhynchinae in order to study further individual clades within the subfamily. More extensive sampling and new sources of data, especially on immature stages and molecular data, will corroborate or refuse the proposed phylogeny. Additionally, further studies are need to establish new combinations and to enlarge the data base available for cladistic analyses.

\section{TAXONOMY}

\section{Metriorrhynchinae Kleine, 1926}

Metriorrhynchinae Kleine, 1926a: 97.

Type genus. Metriorrhynchus Gemminger et Harold, 1869.

Cladophorini Kleine 1928: 222; Bocak \& Bocakova, 1990a: 641.

Type genus. Cladophorus Guérin-Méneville, 1830: Plate II, fig. 9.

Dilolycinae Kleine, 1926: 186; Bocak \& Bocakova, 1990a: 641. Dilolycini: Kleine, 1933: 84.

Type genus. Dilolycus Kleine, 1926a: 186.

Haplothoracinae Kleine, 1926a: 95 (nomen nudum); Bocak \& Bocakova, 1990a: 641.

Type genus. Haplothorax Kleine, 1926a: 95 (nomen nudum).

Diagnosis. Body small to large $(3-30 \mathrm{~mm})$, mostly slender, flat (Figs 7-9), weakly sclerotized. Head small, partly concealed by pronotum. Cranium mostly compact (Fig. 11), seldom rostrate (Fig. 10). Antennae compressed, filiform, serrate or flabellate (Figs 29-51). Mouthparts well developed, mandibles small, moderately curved (Figs 24-28), maxillary palpi 4-segmented (Figs 15-17), labial palpi 3-segmented. Labium simple (Fig. 14). Pronotum with carinae (Figs 57-86). Elytra with four primary and five secondary longitudinal costae (e. g. Figs 52-56), sometimes secondary costae absent (Figs 56, 87, $88,90)$ or primary costae reduced. Longitudinal costae connected by transverse costae. Male genitalia with para- 
meres and retracted, membranous internal sac (Fig. 91) or parameres absent and internal sac sclerotized or exposed (Figs 92-132). Ovipositor with plate-like coxites, small movable styli and sclerotized, rod-shaped valvifers (Figs 133-140). Vagina mostly membranous, seldom sclerotized (Figs 141-160). Spiculum gastrale moderately long to absent (Figs 162-163).

Distribution. Afrotropical, Oriental, and Australian Regions, eastern part of Palaearctic Region, Siberia, Eastern Europe (Fig $3)$.

Remarks. Metriorrhynchinae are easily recognisable within the Lycidae as they have pronotal carinae (Figs 57-86) and a very short antennomere 2 (Figs 30-51). In addition all representatives have a circular phallobase (Figs 91-132), and parameres that are characteristically slender or absent (Figs 91-132).

\section{Conderini Bocak et Bocakova, 1990}

Conderini Bocak et Bocakova 1990a: 643.

Type genus. Conderis C. O. Waterhouse, 1879: 59.

Diagnosis. Body small to medium-sized, most species cinnabar red. Rostrum absent, antennae filiform to weakly serrate (Fig. 29), almost circular in cross-section to weakly compressed. Pronotum with five areoles, median areola often reduced in size, connected with pronotal and basal margins by long carinae (Figs 57, 58). Elytra with four strong primary costae, secondary costae present (Conderis) or absent (Xylobanellus, Fig. 87). Male genitalia with long parameres, base of phallus curved, phallobase with process at base, bases of parameres fused with phallus to form a unique process (Fig. 91). Ovipositor robust, with stout valvifers, small sclerites attached to valvifers (Fig. 133). Vagina membranous, unpaired gland very small, inconspicuous, lateral glands very delicate and very wide at base (Fig. 142).

Distribution. Palaearctic and Oriental Regions. Over 30 species described at present; mainly from China and continental South East Asia.

Remarks. Two genera, Conderis and Xylobanellus are classified as Conderini. Their close relationship is well supported by the unique shape of male (Fig. 91) and female genitalia (Figs 133, 142). They are easily distinguished by the presence or absence of secondary elytral costae. The absence of secondary costae is the only advanced feature found in Xylobanellus, but this occurs independently in many lineages within the Lycidae (several occurences in the Metriorrhynchinae). Unfortunately, Conderis does not have any synapomorphic character state and therefore Conderis can be paraphyletic with respect to Xylobanellus.

\section{Conderis C. O. Waterhouse, 1879}

Conderis C. O. Waterhouse, 1879: 59.

Type species. Calopteron signicolle Kirsch, 1875: 36; C. O. Waterhouse, 1879: 59 (by original designation).

Pseudoconderis Pic, 1921a: 8, hors texte; Bocak, 1998a: 18. Type species. Pseudoconderis gorhami Pic, 1921a: 8; Bocak, 1998a: 18 (by subsequent designation)
Diagnosis. Body small to medium sized, most species cinnabar red. Antennae filiform to slightly serrate (Fig. 29). Pronotum with five areoles (Fig. 58), sometimes median areola reduced in size (as in Fig. 57), narrow, connected with frontal and lateral margins by stout carinae. Elytra parallel-sided to slightly widened posteriorly, each elytron with four stout, longitudinal primary costae and five much weaker, sometimes interrupted, secondary costae. Transverse costae dense, sometimes irregular, bottom of elytral areoles bald. Terminal male abdominal sternite with hole in basal part. Phallus almost straight in middle, parameres long (Fig. 91). Valvifers with attached sclerites, widened in middle part, basal margin of coxites strengthened (Fig. 133). Vagina membranous.

Distribution. Eastern part of the Palaearctic Region (China, Japan), Oriental Region (mainly continental South East Asia, less common in Himalayas and India, as well as in Sundas; easternmost record from Lombok). Over 20 species known from the range of the genus.

Remarks. Many Conderis species share the same characteristic elytral structure. The transverse costae are usually very dense and the bottoms of elytral areoles are bald, mat and the surface has a fungus-like structure. This is the only apomorphic character of Conderis but not all species.

\section{Xylobanellus Kleine, 1930}

Xylobanellus Kleine, 1930a: 171.

Type species. Xylobanellus atricolor Kleine, 1930a: 171 (by original designation).

Rossioptera Kasantsev, 1988: 169, syn. n.

Type species. Eros erythropterus Baudi, 1871 (by monotypy).

Chuzenjianus Kôno, 1932: 61; Nakane, 1969a: 176.

Type species. Chuzenjianus tenuis Kôno, 1932: 61 (by original designation).

Diagnosis. Body small to medium-sized, slender, parallel-sided. Antennae slender, long, slightly serrate. Apical maxillary palpomere triangular. Pronotum almost parallel-sided, posterior angles rectangular. Median areola small, very slender (Fig. 57). Elytra flat, with four stout longitudinal costae, transverse costae well marked, only 20-25 costae per interspace, elytral areoles squared to longitudinal (Fig. 87), their bottom flat, matt, finely chagrined. Male genitalia with slender curved phallus, its apex widened in lateral view. Parameres well developed. Ovipositor robust, vagina membranous.

Distribution. Five species are placed in Xylobanellus, one occurring in Eastern Europe and Siberia, the rest in China, Thailand, Malaysia, Borneo and Java.

Remarks. All Xylobanellus species share several characters, which potentially could be present in a common ancestor: secondary costae absent, rectangular reticulate cells and male segment A7 with straight margin. The similarly structured elytral costae is also encountered in unrelated lineages within the Metriorrhynchinae (e. g. Broxylus, Caenioxylobanus, Xylobanus) and in other subfamilies of Lycidae (Lycinae: Calopterini, part; Erotinae, part). Rossioptera is based on Eros erythropterus, previously classified in Dictyoptera. Bocak \& Bocakova 
(1987a) transferred E. erythropterus to Xylobanellus. Rossioptera is considered to be a junior subjective synonym of Xylobanellus.

\section{Metriorrhynchini Kleine, 1926}

Metriorrhynchini Kleine, 1926a: 97.

Type genus. Metriorrhynchus Gemminger et Harold, 1869: 1629.

Diagnosis. Body small to large. Head mostly lack a rostrum, seldom has a more or less long rostrum. Antennae serrate to flabellate in males, serrate in females, seldom flabellate in females. Pronotum with only median areola and lateral costae present (Figs 61-65, 84), with slender costae forming five areoles (Figs 59-60) or with seven areoles (e. g. Figs 76-83). Elytra with longitudinal and transverse costae. Secondary costae weak to absent (Figs 52-56, 87-90). Male genitalia without parameres (Figs 92-132), with partly sclerotized internal sac, or large, usually finely setose sac exposed on apical part of phallus (Fig. 118). Vagina with paired, lateral, narrowly attached glands (Figs 143-160), and with apparent, flat, unpaired gland (e. g. Figs 143, 145)

Distribution. Afrotropical, Oriental, and Australian Regions and eastern part of Palaearctic Region (Fig. 3).

Remarks. Metriorrhynchini are easily recognisable by the absence of parameres, presence of characteristic pronotal carinae forming up to seven areoles, flat unpaired vaginal gland and narrowly attached lateral glands. Metriorrhynchus Guérin-Méneville, 1838 was considered to be the type genus by Kleine (1926a). Bocak (1998c) discussed the validity of the name.

\section{Hemiconderina Bocak et Bocakova, 1990}

Hemiconderina Bocak et Bocakova 1990a: 645.

Type genus. Hemiconderis Kleine, 1926a: 162.

Diagnosis. Body small to medium-sized, mostly slender, parallel-sided (Wakarumbia, Hemiconderis, Fig. 8, and Achras), seldom shorter, more robust (Synchonnus). Head small, without rostrum. Antennae serrate (Figs 30, 31), antennomeres triangular to parallelsided, always apparently compressed, similar in both sexes. Pronotum with five areoles, carinae straight, slender, median areola small, narrow (Figs 59, 60). Elytra parallel-sided to slightly widened posteriorly (Fig. 8). Elytral costae 2 and 4 stronger, always reaching apex of elytra, costae 1 and 3 always apparently weaker in apical half of elytra, seldom shortened. Secondary costae present in most genera, absent in Wakarumbia. Legs slender, strongly compressed. Male genitalia with simple, slender phallus (Figs 92-96). Internal sac with pair of basal spines, seldom fused in one complex structure (Wakarumbia, Fig. 94). Ovipositor wide, valvifers apparently divergent, vagina membranous, simple (Figs 151, 153).

Distribution. Australian Region: Australia, New Guinea, Yapen Island, Sulawesi, Buton Island (Fig. 5); there was no overlap in the distribution of Wakarumbia, Achras, and Hemiconderis.

Remarks. Hemiconderina are easily distinguished by the shape of their pronotum, with characteristic, slender, straight carinae forming only five areoles on the pronotal disc (Figs 59-60), head without rostrum, and primary costae 1 and 3 weaker apically; rarely also a costa 1 partly shortened (Hemiconderis bipustulatus Bocak \& Bocakova, 1990b). Additionally, all genera placed here share a slender, delicate appearance, with parallel-sided elytra, very slender legs, slender and relatively long maxillary palpi, slightly securifom apical maxillary palpomere, minute labial palpi, and absence of tibial spurs.

\section{Synchonnus C. O. Waterhouse, 1879}

Synchonnus C. O. Waterhouse, 1879: 59.

Type species. Synchonnus clientulus C. O. Waterhouse, 1879 : 59 (by monotypy).

Diagnosis. Body small, quite robust, slightly widened posteriorly. Head small, without rostrum. Antennae robust, strongly compressed, serrate. Maxillary palpi slender, apical palpomere slightly widened. Pronotum with strongly projected hind angles, with five areoles, median areola slender, long. Four primary and five secondary costae extant whole length of the elytra, primary costa 2 and 4 much stronger, costa 3 very weak apically. Secondary costae weak, transverse costae irregular. Male genitalia very slender, phallus widened in apical third, internal sac with two large spines in basal part. Ovipositor with small coxites and long valvifers (Fig. 138), vagina with dorsal sac (Figs 145-146).

Distribution. Australian Region. Five species reported from Australia, New Guinea, and Jobi Island

Remarks. Synchonnus has a basal position in Hemiconderina. As in Achras the male genitalia has a pair of spines (Figs 92-93, 95-96), but unlike this genus it has more robust body and obtuse pronotal carinae.

\section{Achras C. O. Waterhouse, 1879}

Achras C. O. Waterhouse, 1879: 61.

Type species. Achras limbatus C. O. Waterhouse, 1879: 62 (by monotypy).

Diagnosis. Body medium-sized. Head without rostrum. Antennae strongly compressed, slender, only antennomeres 3 and 4 broad, subsequent antennomeres narrow, acutely pointed. Maxillary palpi quite robust. Pronotum with almost straight basal margin and posterior angles acutely projected. Disc with five areoles. Elytra with strong primary costae on humeral third of elytra, much weaker further back, primary costae 1 and 3 much weaker apically, secondary costae on apical third of costa 3 absent, on costa 1 irregular. Transverse costae on elytra weak, irregular, elytral cells mostly slightly transverse. Male genitalia robust, short, with two large spines on basal part of internal sac. Ovipositor with short coxites and long, slender valvifers, vagina large, membranous (Fig. 151).

Distribution. Australian Region: Australia (New South Wales). Monotypic.

Remarks. Achras was classified with Metriorrhynchus and Metriorrhynchoides in the Metriorrhynchini (Kleine, 1933) and later was not studied but kept in the Metriorrhynchina (Bocak \& Bocakova, 1990a). Based on the pre- 
sent analysis it is transferred to the subtribe Hemiconderina. Achras is characterised by sclerotized, widened basal part of spermaduct and lateral sacks at base of vagina. The second character can very between species analogous to the situation in other genera. Achras seems to be very closely related to Wakarumbia but retains several plesiomorphic character states, i. e. vestiges of secondary costae, unrotated phallus, pair of basal spines on internal sac.

Wakarumbia and Achras both have characteristically shaped valvifers (Fig. 151), vagina with unpaired gland located on independent frontal sac, both genera have much weaker costae 1 and 3 , but which extent the whole length of elytra. They have similar, characteristic labrum and slender lateral processes on mesoscutum.

\section{Hemiconderis Kleine, 1926}

Hemiconderis Kleine, 1926a: 162.

Type species. H. explicatus Kleine, 1926a: 162 (by monotypy).

Diagnosis. Body small to medium-sized, slender, coloration usually bright, seldom dull. Head small, without rostrum. Antennae considerably compressed, weakly serrate, reaching beyond elytral apex. Maxillary palpi relatively long, slender, terminal palpomere slightly widened. Pronotum with slender, conspicuous carinae forming 5 areoles. Median areola slender (Fig. 60). Elytra long, slender, with 4 primary costae at base, primary costa 3 shortened, reaching middle of elytra. Primary costa 1 seldom short. Secondary costae well developed, reticulate cells small, regular. Phallus lanceolate, internal sac with two large spines linearly arranged. Female genitalia broad, well sclerotized, coxites free. Valvifers thin, their bases with various projections, widened.

Distribution. Australian Region: New Guinea, Yapen Island. Altogether 9 species known (Bocak \& Bocakova, 1990b).

Remarks. Hemiconderis is the only member of the Hemiconderina having entire secondary costae, shortened primary costa 3 and two spines on internal sac linearly arranged; the first located at base of phallus, the second on apical half. Basal part of valvifers of all females widened to some degree (Bocak \& Bocakova, 1990b). H. bipustulatus Bocak \& Bocakova, 1988 has additionally a shortened costa 1 , but to a considerably smaller degree than encountered in Trichalina.

\section{Wakarumbia Bocak, 1999}

Wakarumbia Bocak, 1999b: 166.

Type species. Wakarumbia gracilis Bocak, 1999b: 167 (by original designation).

Diagnosis. Body small, very slender, delicate, with slender legs and antennae. Head without rostrum. Antennae slightly serrate to parallel-sided. Pronotum with five areoles, pronotal carinae straight and slender. Elytra almost parallel-sided, with four primary costae, primary costae 1 and 3 weak, secondary costae absent, only vestiges present at base of elytra. Transverse costae well developed, regular, elytral cells mostly square-shaped. Phallus with one, complex basal spine on internal sac, in most species apical part of phallus rotated to various degrees.

Distribution. Australian Region: Sulawesi, Buton Island. Altogether 23 species classified in Wakarumbia.

Remarks. Wakarumbia is the only genus of Hemiconderina that lacks secondary costae. Apical part of phallus in most species is characteristically rotated and there is one complex spine at base of the phallus.

\section{Trichalina Kleine, 1928}

Trichalinae Kleine, 1928: 222.

Trichalini Kleine 1933: 69.

Trichalina Bocak et Bocakova, 1990a: 646

Type genus. Trichalus C. O. Waterhouse, 1877: 82.

Diagnosis. Body small to medium-sized. Head without rostrum. Antennae serrate, seldom with short lamellae (several Diatrichalus, Fig. 32), or flabellate (Flabellotrichalus). Pronotum with slender median areola (Figs 62-65), with two divergent carinae (Eniclases, Fig. 66) or with five areoles (Schizotrichalus). Elytra regularly with considerably shortened primary costa 1 (Fig. 9), secondary costae usually well developed, absent in some Diatrichalus. Male genitalia slender with basal spines (Figs 97-99), widened apically with complex sclerotized internal sac (Figs 101-102) or slender, with partly sclerotized apical part, internal sac without basal spines (Figs 104-106) or basal spines apparent (Fig. 103). Ovipositor with simple coxites, valvifers usually long and slender, vagina always membranous, lateral glands usually dorsally attached (Microtrichalus etc.), sometimes laterally attached (Diatrichalus, Enylus only).

Distribution. Australian Region and eastern part of the Oriental Region: Indochina, Thailand, southernmost Yunnan, Peninsular Malaysia, the Philippines, and the Great Sundas (Fig. 5). Highest diversity in New Guinea and Australia, the number of species decreases to the west of the range and only a few species are known from continental Asia.

Remarks. The genera with shortened elytral costa 1 previously classified in the tribe Trichalina were revised recently by Bocak (1998b). Only genera with the characteristic slender phallus and dorsally attached lateral vaginal glands belonged in the Trichalina in the restricted sense, and the sister-group position of Diatrichalus and Enylus was confirmed. The present analysis of the whole subfamily Metriorrhynchinae confirmed the monophyly of the restricted Trichalina and also supports the close relationship of genera Enylus and Diatrichalus to the Trichalina clade. Although the relationship of these genera needs confirming using larval characters and molecular data, the genera Enylus and Diatrichalus are here classified in the Trichalina.

\section{Enylus C. O. Waterhouse, 1879}

Enylus C. O. Waterhouse, 1879: 72.

Type species. E. segregatus C. O. Waterhouse, 1879 (by monotypy).

Strophicus C. O. Waterhouse, 1879: 73, syn. n.

Type species. Strophicus nigellus C. O. Waterhouse, 1879: 73 (by monotypy). 
Diagnosis. Body small to medium-sized. Head small, without rostrum. Antennae strongly compressed, similar in both sexes, serrate or antennomeres almost parallelsided, never flabellate. Maxillary palpi robust, apical palpomere with an oblique apex, broad. Pronotum only with median areola, lateral carinae absent, weak lateral tubercles on lateral margins of pronotum. Elytra with four primary costae, primary costa 1 strong over whole length, costae 2 and 4 much stouter than costae 1 and 3, costa 3 much weaker apically. Legs slender, strongly compressed. Male genitalia always with slender, long phallus, with pair of basal spines, partly sclerotized apically, phallobasal membrane inconspicuous. Ovipositor with short, rather stout valvifers, fused with coxites (Fig. 137), vagina relatively short, bases of glandular ducts robust, accessory glands inserted laterally. Spermatheca slender, very long.

Distribution. Australian Region: New South Wales, New Guinea, and Mysool Island. Only four species are at present classified in Enylus, two of them were originally classified in Strophicus.

Remarks. Enylus is the only genus classified in Trichalina not having a shortened elytral primary costa 1 . Only the holotype of Strophicus nigellus was available, and therefore Strophicus was not included in the phylogenetic analysis. Strophicus is externally very similar to Enylus and the only differs in the size of its eyes: very small in males of Strophicus and very large in Enylus. The presence and/or absence of sexual dimorphism in eye size ise regularly observed in genera of Lycidae. This character is correlated with when in the day they fly. Males of species active at night have large eyes. Therefore, I propose that Strophicus is a junior subjective synonym of Enylus.

\section{Diatrichalus Kleine, 1926}

Diatrichalus Kleine, 1926a: 167.

Type species. D. xylobanoides Kleine, 1926 (by original designation).

Mimotrichalus Pic, 1930: 92, hors texte; Bocak, 1998b.

Type species. $M$. tenimberensis Pic, 1930 (by monotypy).

Diagnosis. Body medium-sized, coloration variable but mostly black or black with metallic blue shine, only a few species have a brightly coloured pronotum and basal part of elytra. Never light concolour. Head small, without rostrum. Antennae strongly compressed, antennomeres parallel-sided to acutely serrate in both sexes, seldom very shortly flabellate in male. Maxillary palpi with broad apical palpomere bearing papillae at apex. Pronotum with one more or less broad longitudinal areola in the middle, lateral margins elevated. Elytral primary costa 1 considerably shortened, reaching at most one third of elytral length, secondary costae irregular to completely absent in some species. Legs relatively strong and short, strongly compressed. Male genitalia with relatively short and robust phallus, internal sac lacks basal spines, regularly strongly sclerotized apically (Figs 100-101). Ovipositor with slender, long valvifers, sometimes incompletely fused at base, vagina relatively short, vaginal glands inserted laterally. Spermaduct robust at base, spermatheca slender, very long.

Distribution. Australian and eastern part of the Oriental Region. Only one species found in continental Malaysia, Java, Borneo and Sumatra. All other Oriental representatives occur in the Philippines. The highest diversity is found in New Guinea. Kleine (1933) placed six species in Diatrichalus. Later, it was found that many Oriental and Papuan species previously classified as Trichalus belonged to Diatrichalus (Bocak, 2000a, 2001a). At present over 40 species are classified in this genus.

Remarks. In all Diatrichalus the basal part of spermaduct is widened and this unique character is considered to be apomorphic state. This genus originally included only species that lacked secondary costae. A study of most species showed that in Diatrichalus there are transitional states between strong secondary costae, weak irregular secondary costae and complete absence of costae. The internal sac and basal part of female spermaduct in Diatrichalus has a very characteristic and unique shape of and both species that have and lack secondary costae are included in this genus.

\section{Trichalus C. O. Waterhouse, 1877}

Trichalus C. O. Waterhouse, 1877: 82.

Type species. T. flavopictus C. O. Waterhouse, 1877: 82; C. O. Waterhouse 1878: 103 (by subsequent designation)

Xantheros Fairmaire, 1877: 167

Type species. $X$. ochreatus Fairmaire, 1877: 167; Bourgeois 1891: 347 (by subsequent designation).

Diagnosis. Body medium-sized, slightly widened posteriorly, antennae serrate in both sexes. Pronotum with one longitudinal median areola, first elytral primary costa shortened, secondary costae always well developed, regular. Male genitalia with slender phallus, internal sac membranous, with pair of spines at base, internal sac exposed, free. Ovipositor with extremely robust valvifers, fused in basal third, flat, closely attached to coxital processes. Vagina robust, lateral glands attached dorsally, their bases widened, unpaired vaginal gland short, spermathecal duct short, spermatheca large, bulbous.

Distribution. Australian Region: only continental Australia.

Remarks. Kleine (1933) cited 112 Trichalus species from the Oriental and Australian Regions. Recent studies indicate that most Oriental and Papuan species previously classified as Trichalus belong to Microtrichalus (Bocak, 1998b, d, 2000d). The Australian Trichalus is badly in need of revision. Widened bases of lateral glands and fused valvifers are the unique apomorphic character states of Trichalus.

\section{Microtrichalus Pic, 1921}

Microtrichalus Pic, 1921b: 9, hors texte.

Type species. M. singularis Pic, $1921 \mathrm{~b}$ : 9 (by monotypy).

Falsoenylus Pic, 1926: 29, hors texte; Bocak, 1998b.

Type species. $F$. basipennis Pic, 1926: 30; (by monotypy).

Diagnosis. Body small to medium-sized, very often with dorsal part of body at least partly yellow to lightly brown. Antennae serrate in both sexes, labial palpi slender, apical palpomere slightly narrowed at apex, com- 
pressed. Pronotum with one longitudinal median areola. First elytral primary costa shortened, secondary costae regularly present. Male genitalia very uniform within genus. Phallus slender, only basally completely sclerotized, ventrally open apically, internal sac exposed, with pair of sickle-like thorns at base, sometimes with $\mathrm{V}$-shaped rod in membrane. Whole of male genitalia often very slightly pigmented and sclerotized, rendering structure of internal sac inconspicuous. Ovipositor with slender valvifers. Vagina slender to moderately robust, with dorsally attached lateral accessory glands whose bases are more sclerotized, proper glands very fine. Two lateral pockets of unknown function are present in lateral part of vagina. Very slender unpaired gland attached to base of vagina.

Distribution. Australian and Oriental Regions: Sunda Islands, the Philippines, Peninsular Malaysia, Thailand, Indochina, and the southernmost part of Yunnan.

Remarks. Many species formerly placed in Trichalus were transferred to Microtrichalus (Bocak, 1998d, 2000 d). At present, 40 species are classified in Microtrichalus, but the faunas of New Guinea and Australia, where the highest diversity is found, have not yet been revised. Lateral pockets and unpaired basal vaginal gland are the unique apomorphic character states of Microtrichalus.

\section{Flabellotrichalus Pic, 1921}

Flabellotrichalus Pic, 1921b: 9, hors texte.

Type species. $F$. notatithorax Pic, 1921b: 9; Kleine, 1936: 4 (by subsequent designation).

Stereotrichalus Kleine, 1926a: 183; Kleine, 1930a: 330.

Type species. S. evidens Kleine, 1926a: 184 (by subsequent designation)

Villosotrichalus Pic, 1921b: 9, hors texte; Bocak, 1998. Type species. $V$. reductus Pic, 1921 b: 9 (by monotypy).

Diagnosis. Body medium sized to large, slightly widened posteriorly. Usually dark brown to black with humeral part of elytra lighter. Head without rostrum, antennae flabellate in male (Fig. 27). Pronotum with one longitudinal median areola, frontal and lateral margins of pronotum very often with dense short to very long pubescence. Elytral primary costa 1 shortened, secondary costae always present. Male genitalia very slender, phallobase usually covered with extensive membrane. Phallus very long, narrow, sclerotized completely only basally, apically sclerotized dorsally, internal sac exposed, pigmented at apex, sometimes with strengthened rod in membrane, never with pair of spines at base. Vagina with two dorsally attached accessory glands, glands very fine, spermaduct long, curved, spermatheca lemon-shaped.

Distribution. Australian Region. Flabellotrichalus is recorded only from New Guinea and Moluccas. At present 13 species are classified in this genus.

Remarks. Long antennal lamellae in male, pubescence on pronotum, and shape of male genitalia are unique characters of Flabellotrichalus within the Trichalina.

Schizotrichalus Kleine, 1926

Schizotrichalus Kleine. 1926a: 183.
Type species. T. nigrescens C. O. Waterhouse, 1879: 70 (by original designation).

Diagnosis. Body small to medium sized, dark brown to black. Antennae slightly serrate in both sexes. Maxillary palpi slender. Pronotum with five areoles. Elytral primary costa 1 shortened, usually secondary costae developed, in one (presently undescribed) species irregular transverse costae and mostly absent secondary costae. Male genitalia with long, slender, only basally well sclerotized phallus, dorsally one strengthened pigmented keel, bearing reversed cup-like apex (Fig. 105). Middle part membranous, with internal sac pigmented apically, no basal spines present. Phallobase without extensive membrane. Ovipositor with long slender valvifers, sometimes connected at bases. Vagina long, slender, lateral accessory glands inserted dorsally, apical gland short. Spermaduct short, straight, spermatheca robust.

Distribution. Australian Region: New Guinea. Monotypic, but several undescribed species have been collected.

Remarks. Schizotrichalus differs in five pronotal areoles from other genera classified in the in Trichalina.

\section{Eniclases C. O. Waterhouse, 1879}

Eniclases C. O. Waterhouse, 1879: 66.

Type species. Lycus (genus 35) luteolus C. O. Waterhouse, 1878 (by original designation).

Trichalolus Pic, 1923: 36, hors texte; Bocak \& Bocakova, 1991. Type species. T. apertus Pic, 1923: 36 (by monotypy).

Diagnosis. Body medium-sized. Head without rostrum, antennae with parallel-sided to serrate antennomeres $3-10$, only a few species antennomeres flabellate in male. Labial palpi slender, apical palpomere parallel-sided. Pronotum divided by two divergent carinae into three fields (Fig. 66). Elytra with first elytral primary costa shortened, with complete secondary costae. Male genitalia with apparent keel on dorsal surface of phallus, with free, membranous internal sac, without sclerotised structures or spines (Fig. 106). Ovipositor with basal processes of coxites attached to valvifers, lateral glands of vagina attached into the middle part of vagina, glands very fine.

Distribution. Australian Region. At present, 26 species are known from New Guinea and one from the Moluccas. Although I have seen very extensive lycid material from the Solomon Islands it contained no species of this genus.

Remarks. Eniclases is characterised by a unique arrangement of pronotal costae. Bocak \& Bocakova (1991) revised this genus.

\section{Metriorrhynchina Kleine, 1926}

Metriorrhynchina Kleine, 1926a: 97; Bocak \& Bocakova, 1990a: 644.

Type genus. Metriorrhynchus Gemminger et Harold, 1869: 1629.

Diagnosis. Body small to large. Head usually without rostrum, several genera with a very small (Leptotrichalus) or long rostrum (Porrostoma, Fig. 10, Metriorrhynchoides, Oriomum). Male antennae often flabellate, the position of lamellae or antennomeres variable within genera, 
lamellae usually robust (Fig. 38), seldom extremely slender and long (Pseudodontocerus, Fig. 45, Cladophorus, Figs 44, 51). Pronotum usually with distinct frontolateral and lateral carinae and small, slender median areola attached to basal margin of pronotum (e. g. Figs 69-74, 76-83), several genera with either only median areola present and lateral costae vestigial (Leptotrichalus, Lobatang, Fig. 75), only frontal keel and median areola strongly marked and lateral and frontolateral carinae vestigial (Bulenides, Fig. 68), or only frontal keel distinct (Caenioxylobanus, Fig. 67). Elytra with primary and secondary longitudinal costae connected by transverse costae (Figs 52-55, 89), secondary costae sometimes absent (Figs 56, 88, 89). Male genitalia without parameres, often lanceolate with pair of spines apically (Figs 107-12), robust, with basal spiens (Figs 125-28) or tubular with exposed membranous internal sac (Figs 115-20). Female genitalia with simple coxites, membranous or more or less sclerotized vagina, large unpaired gland and pair of lateral glands.

Distribution. Afrotropical, Oriental, Australian Regions and eastern part of the Palaearctic Region. Coincident with distribution of Metriorrhynchini (Fig. 3).

\section{Bulenides C. O. Waterhouse, 1879}

Bulenides C. O. Waterhouse, 1879: 34.

Type species. Lycus (genus 21) obsoletus C. O. Waterhouse, 1878: 109; Bourgeois, 1891: 345 (by subsequent designation).

Diagnosis. Body small to medium sized. Head without rostrum. Antennae robust, flabellate in male, lamellae short and robust (as in Fig. 38), serrate in female. Maxillary palpi slender, apical palpomere pointed. Pronotum often narrowed anteriorly, with robust frontal margin (Fig. 68), disc with one small median areola, regularly with vestiges of frontolateral costae. Elytra with four strong, entire primary costae and weak but regular secondary costae. Elytral cells minute. Phallus slender, lanceolate, internal sac with two spines on apical third of phallus. Vagina membranous, spermaduct short, spermatheca lemon-shaped (Fig. 155).

Distribution. Eastern part of Oriental Region: Burma, Thailand, Indochina, Taiwan, Peninsular Malaysia, Sumatra, Java, Borneo, and the Philippines.

Remarks. Bulenides is characteristic in having only a small, narrow areola in middle of pronotum, the carinae forming the areola can be obtuse to absent and consequently only a strong frontal keel is present on pronotum. The shape of pronotum is variable, but often distinctly narrowed frontally. The shape of pronotum is similar to that of Caenioxylobanus, which differs in the complete absence of secondary elytral costae and tibial spurs. Additionally, the form of the frontal margin of the pronotum in Bulenides and Caenioxylobanus is unique (Figs 67-68). This character state was confirmed in B. obsoletus (type species) and some other species but is absent from some species included in Bulenides. Only a complete revision of Bulenides will clarify the limit of the genus.

\section{Caenioxylobanus Pic, 1922}

Caenioxylobamus Pic, 1922: 13, hors texte.
Type species. Caenioxylobanus ater Pic, 1922 (hereby designated).

Diagnosis. Body medium-sized, completely dark brown to black. Head without rostrum. Antennae robust, strongly compressed, flabellate in male, serrate in female (Fig. 39). Maxillary palpi robust. Pronotum trapezoidal, with a distinct protruding frontal margin, which is formed by a robust vertical surface (Fig. 67). One longitudinal keel present on disc, anterior half of keel sharp and narrow, higher than wide at base, in basal part almost absent, transformed into a very wide, flat mound. Elytra flat, with four longitudinal costae and slender transverse costae. All costae very regular, slender and sharp. Reticulate cells quadrate to slightly transverse (Fig. 88), all costae shiny, black, bottom of cells velvet, dark brown. Male genitalia slender, lanceolate, internal sac with two spines on apical third. Ovipositor robust (Fig. 135), vagina membranous, spermatheca long, bulbous apically (Fig. 140).

Distribution. Afrotropical Region: Madagascar. Two species are endemic to Madagascar.

Remarks. Pronotal carinae of Caenioxylobanus have a unique shape and this genus differs from the closely related Bulenides in the absence of secondary costae and in the mat, velvet bottoms to the elytral cells.

\section{Xylobanus C. O. Waterhouse, 1879}

Xylobanus C. O. Waterhouse, 1879: 38.

Type species. Lycus costifer Walker, 1858: 282 (by original designation).

Invalid designation. Xylobanus fastidiosus C. O. Waterhouse, 1879: 39; Bourgeois, 1891: 345.

Diagnosis. Body small to medium-sized, often slender, parallel-sided. Head without rostrum. Antennae serrate to flabellate in male, lamellae if present short, robust (as in Fig. 38), more or less serrate in female. Maxillary palpi robust, apical palpomere almost parallel-sided to considerably widened. Pronotum trapezoidal, usually with seven strongly marked areoles (Fig. 69), in some species lateral and frontolateral carinae obtuse to reduced. Elytra with four well developed, strong longitudinal primary costae, secondary costae absent, elytral reticulate cells transverse, regular. Male genitalia slender, phallus lanceolate as in Cautires (Fig. 108) or widened in apical part (Figs 109, 110). Ovipositor short, with robust valvifers (Fig. 154), vagina short, membranous, spermatheca long, slender to lemon-shaped.

Distribution. Afrotropical, Australian, and Oriental Regions, Palaearctic Region: China, Japan, Korea, and Russian Far East. Almost 300 species are described for this genus.

Remarks. Xylobanus is an extremely species rich and widespread genus. It is characterised by a pronotum with seven areoles (although the carinae can be obtuse to vestigial on some parts of the pronotum, frontolateral and lateral pronotal carinae are never completely absent) and elytra lack secondary costae (they are present at most vestigially on narrow humeral part). Xylobanus and Cautires have a similar shaped pronotum and male and female genitalia. Their close relationship is supported by their 
very similar larvae (Potozkaja, 1981, Bocak \& Matsuda, in press). The affinities with Broxylus are discussed further. Several characters of Xylobanus are variable. The phallus is widely rounded apically and primary gonoporus is sclerotized in many species, including the type species Xylobanus costifer, but the apex is pointed and the gonoporus membranous in $X$. corporaali Pic, 1922 from Sumatra. On the other hand these species both have phallus with a wide base. Xylobanus costifer has valvifers connected at base, as does one species from Bali and some other species, but this sclerite is vestigial or absent in other species. Also presence of spiculum gastrale is variable and some species have flabellate antennae (e. g. $X$. nigrimembris Pic, 1926d), or serrate antennae ( $X$. humifer Walker, 1858). Only an extensive, detailed alphataxonomical study can clarify the concept of Xylobanus. The absence of secondary costae is an advanced feature, which has evolved several times in Lycidae.

\section{Broxylus C. O. Waterhouse, 1879}

Broxylus C. O. Waterhouse, 1879: 20.

Type species. ?Calopteron pfeifferi C. O. Waterhouse, 1878 106 (by monotypy). The name was cited by Waterhouse (1878) with a question mark before the generic name indicating provisional generic classification.

Samanga Pic, 1921b: 9, hors texte, syn. n.

Type species. Samanga fenestrata Pic, 1921b: 9 (by monotypy)

Diagnosis. Body medium-sized. Head small, antennae reach beyond the middle of the elytra, compressed. Palpi strongly compressed, maxillary palpi with long, spoonlike apical palpomere, palpomere 4 as long as combined length of palpomeres 1-3, labial palpi short, apical palpomere large (Fig. 15). Pronotum with partly reduced carinae, frontolateral carinae present on areola only, lateral carinae weak (Fig. 70). Elytra flat, widest in apical tenth or strongly hemispherically widened, with four longitudinal, sharp primary costae and thin, sharp transverse costae of similar strength. Elytral cells quadrate to apparently longitudinal (Fig. 90). Legs slender, strongly compressed. Trochanters very slender, long. Male genitalia as figured (Fig. 111).

Distribution. Australian Region: Sulawesi. Altogether 11 species known from Sulawesi (Bocak \& Jašš, in press).

Remarks. Broxylus was classified in the Calopterini (Lycinae) and transferred to the Metriorrhynchinae recently by Bocakova (in press). Samanga and Broxylus are very closely related. They have similar shaped genitalia and large, flat apical palpomeres. These taxa also have quadrate elytral cells with distinct concave bottoms (these are unique in Metriorrhynchinae) and reduced lateral carinae on the pronotum. Thanks to the considerably dilated elytra Broxylus has a very characteristic general appearance. The last mentioned character is the only difference between Broxylus and Samanga and therefore I propose Samanga to be a junior synonym of Broxylus. Elytra of Broxylus fenestratus are less dilated and similar to those of Xylobanus.

Broxylus is very close to Xylobanus from which it differs in the shape of its terminal palpomeres. We do not have reliable synapomorphic character state for Xylobanus, and therefore Broxylus may be a modified member of Xylobanus.

\section{Cautires C. O. Waterhouse, 1879}

Cautires C. O. Waterhouse, 1879: 36.

Type species. Lycus (gen. 22) excellens C.O. Waterhouse, 1878: 110; Bourgeois, 1891: 345 (by subsequent designation)

Diagnosis. Body small to medium sized. Head without rostrum. Antennae flabellate in male (Fig. 38) and serrate in female. Maxillary palpi robust, apical palpomere widened, securiform. Pronotum trapezoidal, disc with seven areoles (Fig. 71), seldom lateral carinae partly reduced. Elytra with four entire longitudinal primary costae. Secondary costae considerably weaker, but well developed. Transverse costae regular, as strong as secondary longitudinal costae. Phallus slender, lanceolate, internal sac with two spines on apical third of phallus (Fig. 108). Ovipositor slender, valvifers subtle, vagina membranous, spermatheca lemon-shaped (Fig. 149).

Distribution. Afrotropical and Oriental Regions; Palaearctic Region: Russian Far East, China, Japan, Taiwan. Although Cautires was reported by Kleine (1926a, 1933) from New Guinea, I have not found any Cautires from this region and Kleine's illustrations of male genitalia are similar to those of Cladophorus or Cautiromimus. In the south-east, the furthermost records of Cautires are from the Philippines, Borneo and Lesser Sundas (Sumbawa). I have not found any representative in Sulawesi or Moluccas and it is not present in New Guinean material. The highest diversity occurs in continental South East Asia, Sumatra, Java and Borneo. Cautires is the commonest lycid in Madagascar, but it is rare in continental Africa, although many species are reported from there.

Remarks. All characters used for the definition of Cautires (seven pronotal areoles, entire elytral costae and shape of genitalia) are symplesiomorphic character states and at present no apomorphic character state is known. An alpha taxonomic study of the Cautires clade will lead to a better understanding of the relationships.

\section{Prometanoeus Kleine, 1925}

Prometanoeus Kleine, 1925c: 133.

Type species. Prometanoeus ochraceus Kleine, 1925c: 133 (by monotypy).

Tapromenoeus Bocak and Bocakova, 1989: 327, syn. n.

Type species. Xylobanus hirtus Kleine, 1928: 234 (by original designation).

Diagnosis. Body small. Head without rostrum. Antennae slender, weakly serrate, flattened (Fig. 37). Maxillary apical palpomere pointed (Fig. 16). Pronotum with short median areola attached to frontal margin by relatively long keel. Frontolateral carinae less apparent (Fig. 72). Elytra with three primary longitudinal costae. According to structure of basal part of costae, primary costae 1, 2 and 4 present, costa 3 absent, vestiges of it make base of costa 4 stouter. Secondary costae weak, irregular or absent. Transverse costae obtuse, weak, irregular to well developed. Elytra densely pubescent or with erect bristles. Phallus lanceolate, apical fourth wider, 
internal sac with two spines. Ovipositor moderately slender, vagina membranous.

Distribution. Oriental Region: Ceylon. Two species classified in this genus.

Remarks. The shape of genitalia and pronotal carinae indicate a close relationship between Prometanoeus and Cautires. They differ in absence and/or presence of flabellate antennae in male. The flabellate antennae evolved several times in Lycidae. The monotypic genera Prometanoeus and Tapromenoeus are very closely related and although they are different in general appearance they have a similar shaped pronotum, pubescence on elytra, and a similar shaped aedeagus. Bocak \& Bocakova (1989) based Tapromenoeus on the absence of secondary costae but the analysis showed that the reduction of secondary costae happened several times in the Metriorrhynchinae and is also often encountered in other subfamilies of Lycidae. Prometanoeus does not have any reliable apomorphic character state that separates it from Tapromenoeus. Therefore I consider Tapromenoeus to be a junior subjective synonym of Prometanoeus.

\section{Metanoeus C. O. Waterhouse, 1879}

Metanoeus C. O. Waterhouse, 1879: 73.

Type species. Lycus (gen. 37) conformis C. O. Waterhouse, 1878: 115; Bourgeois, 1891: 347 (by subsequent designation).

Diagnosis. Body small to medium-sized, elytra at most slightly widened posteriorly. Head small, without rostrum, with large eyes even in females. Male antennal lamellae long, narrowly attached to basal parts of antennomeres (Fig. 40). Maxillary palpi relatively slender, apical antennomere parallel-sided. Pronotum with seven areoles, carinae obtuse (Fig. 73). Phallus wide basally (Fig. 113). Phallobasal membrane extensive, at least partly sclerotized. Internal sac with three pairs of spines. Vagina often considerably sclerotized, form of sclerotisation highly species specific, narrowed to apex (if vagina rounded, then basal part of spermaduct is robust), unpaired gland attached basally to apically, basal position correlated with sclerotisation of vagina, lateral glands large to medium sized, attached ventrally, when vagina sclerotized, laterally if membranous, basal part of glandular ducts more or less sclerotized. Spermaduct usually extremely long, sometimes of medium length (in species with membranous vagina). Female valvifers considerably shortened, modified in plates (Fig. 150).

Distribution. Oriental Region. The highest diversity found in Borneo, Sumatra, and Peninsular Malaysia. Metanoeus is very rare in western part of Oriental Region. One species is common in Mindanao. Altogether over 20 species are classified in Metanoeus.

Remarks. The very obtuse pronotal carinae and vestigial valvifers are characteristic of Metanoeus. Similar obtuse carinae are found in some Metriorrhynchus, which differ in the much shorter lamellae of male antennae, long slender phallus and only shortened valvifers. The sclerotisation of vagina, long processes on scutellum and long, basally attached male antennal lamellae reminiscent of some Papuan representatives of the Metriorrhynchinae.
No genera bearing similar characters were found within the range of Metanoeus. Further characters supporting the relationship of Metanoeus within Metriorrhynchina are need.

\section{Metriorrhynchus Gemminger et Harold, 1869}

Metriorrhynchus Gemminger et Harold, 1869: 1629.

Type species. Lycus parallelus Guérin-Méneville in Boisduval, 1835: 114; C. O. Waterhouse, 1878: 101 (by subsequent designation).

Metriorhynchus Guérin-Méneville, 1838: 72 (a junior homonym of Metriorhynchus Meyer, 1830).

Type species. Lycus parallelus Guérin-Méneville in Boisduval, 1835: 114; C. O. Waterhouse, 1878: 101 (by subsequent designation).

Invalid designation. Metriorrhynchus cribripennis C. O. Waterhouse, 1879: 52; Bourgeois, 1891: 347 (by subsequent designation).

Dilolycus Kleine, 1926a: 186, syn. n.

Type species. Dilolycus lamellatus Kleine, 1926a: 186 (by original designation).

Flabelloporrostoma Pic, 1923: 35, hors-texte (as subgenus of Porrostoma), syn. n.

Type species. Porrostoma mirabilis Pic, 1923: 35 (by monotypy).

Diagnosis. Body large, parallel-sided. Head small, with short, stout rostrum or without rostrum, galeae long, much longer than mandibles. Antennae serrate in both sexes or flabellate in male and serrate in female (Fig. 36). Maxillary palpi slender, long, apical palpomere slender, compressed, pointed at apex (as in Fig. 14). Pronotum with seven, in middle sometimes reduced, areoles on disc. Four strong elytral primary costae developed, costa 3 sometimes slightly shortened (by one eighth at most), slightly weaker in apical half of elytra. Secondary costae much weaker. Transverse costae dense, regular, a bit stronger than secondary costae, elytral cells transverse, regular. Phallus stout, internal sac without spines but with a sclerotised structure (Fig. 114) or similar structure accompanied by several pairs of short minute rods (Bocak, 1998c, Figs 1, 2). Ovipositor small, only partly sclerotized, with short valvifers (Fig. 134), vagina large, often at least partly sclerotized (Fig. 148; Bocak 1998c, Figs 6, 7).

Distribution. Australian Region and eastern part of Oriental Region: Peninsular Malaysia, Thailand, Laos, Sundas, and the Philippines. Metriorrhynchus sericeus C. O. Waterhouse, 1879 is reported from India (Kleine, 1933), but Metriorrhynchus was not found in the recently collected material from India. Highest diversity is found in the Papuan Subregion and Australia, but fauna of these regions is badly in need of revision at the species level. Calder (1998) combined all Australian species of Metriorrhynchus with Porrostoma, because of the doubtful status of the name Metriorhynchus Guérin-Méneville, 1838.

Remarks. There are two types of vagina in Metriorrhynchus: $M$. parallelus (type-species) has a completely sclerotized vagina but species in the $M$. thoracicus Fabricius, 1801 group have a completely membranous vagina. These groups have a similar shaped paraproctus, very 
slender, reduced valvifers and a very strong membrane in which the ovipositor is enclosed.

Dilolycus was proposed for a species with considerably reduced carinae in the middle of the pronotum (Fig. 85). It has similar shaped male genitalia to the Papuan group of species (as in Bocak, 1998c, Figs 1, 2). Therefore I consider Dilolycus to be a junior subjective synonym of Metriorrhynchus.

The holotype of Metriorrhynchus mirabilis has damaged antennae, only the three basal antennomeres of each antenna remain preserved, antennomere 3 is serrate. Two fragments of antennae were glued on the separate label: the first fragment was serrate, corresponding to the remaining antennomeres on the holotype, the second fragment flabellate. It must be part of a different specimen, because it is made up by antennomeres 3-11. The name Flabelloporrostoma and its generic status are based on this incorrectly identified body part. Therefore, I propose Flabelloporrostoma to be a junior subjective synonym of Metriorrhynchus.

\section{Lobatang Bocak, 1998}

Lobatang Bocak, 1998b: 190.

Type species. Lobatang papuensis Bocak, 1998b: 190 (by original designation)

Diagnosis. Body slender, externally similar to Trichalus (general body form, shortened first elytral primary costa, only one longitudinal areola in middle of pronotum, Fig. 9), medium-sized to moderately large. Head without rostrum. Antennae long, strongly compressed, antennomeres 3-10 almost parallel-sided to serrate in both sexes. Maxillary palpi with slender apical palpomere. Pronotum with one longitudinal, median areola, lateral margins parallel-sided or pronotum much wider at base. Elytra flat, with shortened primary costa 1, usually with apparent secondary costae, in one species secondary costae distinctly weaker than transverse ones, irregular, interrupted. Legs long, slender, hind trochanters much wider apically. Phallus robust only at base, slender and apical two thirds very gradually narrowed, internal sac completely sclerotized. Phallobase robust, membrane partly sclerotized (Fig. 116). Ovipositor short and wide, valvifers robust, vagina wide, accessory glands inserted laterally, glandular ducts very short, unpaired apical gland as long as vagina.

Distribution. Australian Region: New Guinea, Moluccas, Sulawesi; Oriental Region: the Philippines.

Remarks. Leptotrichalus and Lobatang has same shaped female genitalia, especially the shortened, widened valvifers. Lobatang is characterised by the unique modification of the internal sac, which has not been found in other Lycidae.

\section{Leptotrichalus Kleine, 1925}

Leptotrichalus Kleine, 1925a: 296.

Type species. Metriorrhynchus cyaniventris Kirsch, 1875 (by original designation).

Diagnosis. Body medium-sized to large, slender, slightly widened posteriorly. Head small, without or with very short rostrum. Antennae compressed, antennomeres 3-10 parallel-sided to slightly serrate, never flabellate. Pronotum slender, long, apparently narrowed frontally (Fig. 75), only very slender longitudinal areola in middle of pronotum, sometimes less apparent lateral carinae present on middle of lateral pronotal margin. Elytra slender, with considerably shortened primary costa 1 and with entire secondary costae. Legs very long, slender, strongly compressed. Male genitalia very diverse in shape, often slender, tube-like, internal sac without any basal spines, rarely with strengthened sclerotized parts. Phallobase often with large, well sclerotized membrane. Ovipositor with short valvifers, vagina short, accessory glands attached laterally, unpaired vaginal gland large, spermatheca bulb-like.

Distribution. Australian Region: Lesser Sundas, Moluccas, and Sulawesi; Oriental Region: Sunda Islands, the Philippines, Malaysia, Thailand and Indochina. Altogether almost 60 species are classified in Leptotrichalus with highest diversity in the Philippines.

Remarks. The relationship between Leptotrichalus and Lobatang is supported by prolonged galees, very wide base of male sternum A8, strong, shortened valvifers and generally short and wide ovipositor and the slender and asymmetrical shape of basal part of phallus. They differ in the prolonged pronotum in Leptotrichalus and the sclerotized internal sac in Lobatang. Additionally, the apical maxillary palpomere is more slender in Leptotrichalus.

\section{Stadenus C. O. Waterhouse, 1879}

Stadenus C. O. Waterhouse, 1879: 61

Type species. Porrostoma dichroum C. O. Waterhouse, 1877: 86 (by original designation).

Diagnosis. Body medium-sized. Head small, without rostrum. Antennae stout, serrate. Maxillary palpi with almost parallel-sided apical palpomere, without papillae, apex obliquely cut. Pronotum wide, almost straight at basal margin, widest before base, mostly only median areola present (see remarks), but at least small vestiges of frontolateral carinae are regularly present (Fig. 76). Primary costae strong, almost completely developed, costa 2 and 4 apparently stronger in apical part, other primary costae very slightly shortened, weaker. Phallus simple, slender, internal sac without spines or sclerotisation (Figs 117,118 ). Female genitalia with very robust and wide valvifers, which are firmly fused with coxites, vagina membranous, large (Figs 156, 159).

Distribution. Australian Region. Five species are placed in Stadenus. The Afrotropical species previously classified in Stadenus are now placed in the tribe Slipinskiini (Erotinae) (Bocak \& Bocakova, 1992).

Remarks. The very similar shape of male and female genitalia supports the affinity of Stadenus and Porrostoma. Porrostoma differs in presence of rostrum, Stadenus has completely fused coxites and valvifers. Stadenus was originally defined by three areoles on the pronotal disc, but this character is unreliable. I have studied male and female Stadenus triareolatus in copula 
(BMNH). They are externally very similar and without any doubt they are conspecific. The female specimen has three areoles, the male seven areoles. But even the female specimen has some vestiges of frontolateral carinae.

\section{Porrostoma Castelnau, 1838}

Porrostoma Castelnau, 1838: 26.

Type species. Lycus rufipennis Fabricius, 1801 (by monotypy). Invalid designation. Porrostoma erythropterum Erichson, 1842; C. O. Waterhouse, 1879: 44.

Diagnosis. Body medium sized to large. Head with long rostrum (Fig. 10). Antennae serrate to flabellate in male (Figs 42, 49), serrate in female. Maxillary palpi slender, apical palpomere slender, almost parallel-sided, hypopharynx very long, mandibles minute. Pronotum with seven strongly marked areoles, carinae usually very strong (Fig. 77). Elytra with entire primary and secondary longitudinal costae. Transverse costae regular, dense, cells usually strongly transverse (Fig. 52). Male genitalia short, robust to slender and long, but regularly simple, parallel-sided, internal sac membranous, without spines (Fig. 119). Female genitalia with robust valvifers, very closely attached to coxites, vagina membranous, relatively short (Bocak, 1998c, Fig. 14).

Distribution. Australian Region. Porrostoma is the commonest lycid in Australia, where the highest diversity is found. Several species are known from New Guinea.

Remarks. Porrostoma was for long time considered a junior synonym of Metriorrhynchus. The name was used by C. O. Waterhouse (1877) and later sometimes inconsistently by Pic. Kleine (1933) listed Porrostoma as a junior synonym of Metriorrhynchus. Calder (1998) used Porrostoma as a junior replacement name for Metriorhynchus Guérin-Méneville and proposed 85 new combinations with Porrostoma (only Australian fauna). Bocak (1998c) replaced Metriorhynchus Guérin-Méneville by Metriorrhynchus Gemminger et Harold, used Porrostoma as a valid taxon and differentiated between Metriorrhynchus and Porrostoma. The identity of most species classified in Porrostoma is unknown and this genus is badly in a need of revision.

\section{Metriorrhynchoides Kleine, 1926}

Metriorrhynchoides Kleine, 1926a: 118.

Type species. Metriorrhynchoides helleri Kleine, 1926a: 119 (by original designation).

Diagnosis. Body large, conspicuously widened posteriorly. Head small with long, laterally compressed rostrum (as in Fig. 10). Antennae slender, flattened, serrate in both sexes (Fig. 43). Apical maxillary palpomere flat, narrowed to apex. Maxillae long. Pronotum with seven strongly marked pronotal areoles, median areola large, widest in frontal part (Fig. 78). Frontolateral carinae short. Pronotum constricted in basal third. Elytra wide, much wider than abdomen, with elevated humeri. Four primary longitudinal costae strong over whole length, costae 2 and 3 sometimes fused before apex. Secondary costae weak but continuous (Fig. 55). Transverse costae very dense, regular. Elytral cells transverse (Fig. 55) Male genitalia slender, internal sac membranous (Fig.
120). Ovipositor with slender coxites and stout valvifers (Fig. 136), vagina membranous, short.

Distribution. Australian Region: New Guinea, only four species classified in Metriorrhynchoides.

Remarks. Metriorrhynchoides is closely related to Porrostoma. Its pronotal carinae are very similar to those of Porrostoma and additionally they both have a long rostrum. Metriorrhynchoides is characterised by a widened apical part of elytra and costae 2 and 3 fused before apex of elytra. Additionally, Metriorrhynchoides species are a bright metallic blue with bright yellow body parts unlike Australian Porrostoma. All males of Metriorrhynchoides also have serrate antennae. I have not found an apomorphic feature defining Porrostoma, therefore it is very probable that Metriorrhynchoides is a subgroup of Porrostoma and will be synonymised with it in the future.

\section{Cladophorus Guérin-Méneville, 1830}

Cladophorus Guérin-Méneville, 1830: Plate II, Fig. 9.

Type species. Cladophorus formosus Guérin-Méneville, 1830; C. O. Waterhouse, 1878 (by subsequent designation).

Odontocerus Guérin-Méneville, 1830: 72; a homonym of Odontocerus Stephens, 1829; C. O. Waterhouse, 1878: 96.

Type species. Cladophorus formosus Guérin-Méneville, 1830; Bourgeois, 1892: 495 (by subsequent designation).

Spacekia Strand, 1936; Bocak, 1998c: 247.

Type species. Cladophorus formosus Guérin-Méneville, 1830 (Spacekia proposed by Strand, 1936 as a nomen novum for Cladophorus)

Diagnosis. Body medium sized to large, often brightly coloured. Head without rostrum. Antennae with very long lamellae in male (Figs 44, 51), serrate in female. Maxillary palpi stout, apical palpomere securiform. Pronotum often apparently transverse, with strongly marked seven areoles (Fig. 79). Elytra with entire primary and secondary longitudinal costae. Phallus gradually narrowed to apex, internal sac partly sclerotized. Phallobasal membrane apparently pigmented and additionally margin of phallobase partly sclerotized, with attached membrane. Membrane has a characteristic structure (Fig. 121) and usually reaches halfway along phallus. Ovipositor moderately wide, simple, valvifers slender (Fig. 141). Vagina membranous with short spermaduct and gradually widened spermatheca (Fig. 144)

Distribution. Australian Region: New Guinea, Australia. All records outside this region refer to other genera.

Remarks. Cladophorus is defined by the form of its phallus and unique shape of phallobasal membrane (Fig. 121), which has not yet been found in other genera of Metriorrhynchinae. At least several dozens of species with this type of aedeagus are known from New Guinea (Kleine, 1926a). On the other hand, most of almost 200 species previously placed in Cladophorus are not congeneric with the New Guinean species (all species from the Oriental, Palaearctic and Afrotropical Regions). Kleine classified as Cladophorus all species that have slender antennal lamellae (mostly Cautires). Pic often used the name Odontocerus Guérin-Méneville nec Stephens and these species were transferred to Cladophorus by Kleine 
(1933). Pic's concept is unclear and his descriptions do not allow identification bellow subfamily level.

\section{Procautires Kleine, 1925}

Procautires Kleine, 1925b: 32

Type species. Procautires toxopei Kleine, 1925b: 32.

Diagnosis. Body medium sized, moderately robust, parallel-sided. Head without rostrum. Antennae flabellate in male, serrate in female. Maxillary palpi short, apical palpomere securiform, maxillae short, wide, mandibles very slender, curved. Pronotum with strong carinae and seven distinct areoles. Elytra with four strong longitudinal primary costae, secondary costae present on basal fifth and apical two fifths of elytra. Elytral cells minute, rounded to square in basal and apical parts of elytra, strongly transverse in the middle. Male genitalia relatively slender, slightly widened apically, internal sac with sclerotized basal part and primary gonoporus, phallobasal membrane pigmented, structured (Fig. 126). Ovipositor slender, coxites almost as long as valvifers, between coxites triangular sclerite, valvifers slender. Vagina short, small, membranous, reaching two thirds of length of valvifers.

Distribution. Australia Region: Australia, New Guinea and Moluccas. There are several Afrotropical and Oriental species now classified in Procautires but they are not congeneric with Procautires toxopei and should be classified with Cautires or another closely related genus. These species have less conspicuous secondary costae, but do not share other characters with the type species.

Remarks. Procautires is characterised by a unique modification of elytral secondary costae. With Kassemia and Cautiromimus it shares the same shape of phallus and sclerotisation of internal sac and with Cladophorus pigmented phallobasal membrane, although it is in this case less extensive and does not have the characteristic structure as in Fig. 121. Additionally, I have found a relatively large sclerite between coxites. Very small structure in similar position is present also in some Cautiromimus (Fig. 160). The sclerite between bases of coxites is reminicent of sclerite found in some species of Xylobanus (Fig. 154), but unlike in Xylobanus, the sclerite is not connected with valvifers and is located between bases of coxites. Therefore I do not consider these structures to be homologous.

\section{Cautiromimus Pic, 1926}

Cautiromimus Pic, 1926c: 454

Type species. Cladophorus reticulatus Kleine, 1926a: 143 (by monotypy).

Diagnosis. Body medium sized, relatively slender. Head small, without rostrum. Male antennae flabellate, female antennae serrate. Maxillary palpi with almost parallel sided apical palpomere, without papillae. Middle pronotal areola very narrow, deep, attached to the basal margin by very short keel, reaching almost $3 / 4$ of pronotal length, frontolateral carinae very strong, but weak in frontal punctured area, absent in frontal quarter, lateral carinae are not connected with median areola (Fig. 81). Posterior half of pronotum shining, pubescent. Elytra par- allel sided, with four primary and five secondary costae extending the whole length, primary costae stronger at humeri, weak in apical fifth. Transverse costae forming quadrate, rounded cells to slightly longitudinal rounded cells. Phallus stout, two plates at base of internal sac, primary gonoporus circular, sclerotized (Figs 122, 123). Vagina very slender, its wall partly stiffened (Fig. 160).

Distribution. Australia Region: New Guinea, Moluccas. At present only C. reticulatus is classified here, but several undescribed species exist in collections.

Remarks. Ditua is similar to Cantiromimus but it differs in serrate male antennae and in the pattern of pronotal carinae. An alpha taxonomic revision of material in collections will clarify of their relationship.

\section{Ditua C. O. Waterhouse, 1879}

Ditua C. O. Waterhouse, 1879: 33.

Type species. Ditua deplanata C. O. Waterhouse, 1878: 100, 109 (by monotypy)

Invalid designation. Ditua dichroma (Boisduval, 1835: 123); Bourgeois, 1891: 345.

Diagnosis. Body medium sized, parallel-sided. Head without rostrum. Antennae serrate in both sexes, antennomeres more acutely triangular in male. Maxillary palpi slender, apical palpomere parallel-sided, slender. Mandibles long, slender, curved. Pronotum transverse, with slightly convex frontal margin. Seven areoles on disc, all carinae very strong (Fig. 80). Elytra with four entire primary and five secondary longitudinal costae, transverse costae dense, reticulate cell minute, quadrate to rounded. Male genitalia with robust phallus, internal sac with basal sclerotized structures and sclerotized primary gonoporus (Fig. 125). Ovipositor slender, vagina membranous.

Distribution. Australian Region: New Guinea. Two species are classified here but several undescribed species exist in collections.

Remarks. Ditua is reminiscent of Cautiromimus but differs in that male antennae are serrate and in the shape of pronotum. Ditua deplanata is a member of a very common lycid Müllerian mimicry complex and I have found in collections several not very closely related species identified as Ditua dichroma. The name $D$. deplanata was up to now used as the junior synonym of Ditua dichroma along with two other names. The status of the synonyms of Ditua dichroma was not checked.

\section{Kassemia Bocak, 1998}

Kassemia Bocak, 1998b: 195.

Type species. Kassemia oculata Bocak, 1998.

Diagnosis. Body small to medium sized, parallel-sided, all representatives dark brown to brown with humeral quarter to half of elytra light yellow to brown, always distinctly much lighter than the rest of elytra. Head small, without rostrum, mandibles slender, long, three times longer than labrum, apical maxillary palpomere robust, securiform, broad. Antennae strongly compressed, flabellate in males and serrate in females. Pronotum with seven areoles. Elytral secondary costae completely absent, primary costa 1 shortened, costa 2 and 3 sometimes fused 
before apex. Legs relatively strong and short, strongly compressed. Male genitalia with relatively short and robust phallus, apical part widely open, internal sac strengthened at base with spine-like structure. Phallobasal membrane never sclerotized. Ovipositor with slender, long valvifers, vagina as long as valvifers, widest at apex, accessory glands inserted laterally.

Distribution. New Guinea, four species known at present (Bocak, 1998b)

Remarks. The combination of seven areoles on the pronotum, complete absence of elytral secondary costae, shape of male genitalia, and shortened primary costa 1 confirm the sure identification of Kassemia. The shape of male antennae and shape of male and female genitalia show little assotiation with shortened primary costa 1 in other genera. The shape of phallus indicates a close relationship with genera of the Cladophorus - Ditua - Cautiromimus clade.

\section{Pseudodontocerus Pic, 1921}

Pseudodontocerus Pic 1921b: 12, hors texte.

Type species. Pseudodontocerus pulcher Pic, 1921b: 12 (by monotypy).

Carathrix Kleine, 1926a: 149, syn. n.

Type species. Carathrix pilosus Kleine, 1926a: 149 (by original designation).

Diagnosis. Body slender, medium sized. Head without rostrum. Lamellae of male antennae extremely long (Fig. 45). Female antennae flabellate, very slender, antennomeres 2 and 3 with lamella shorter than antennal trunk (Figs 46, 47), lamellae gradually prolonged, and on middle and apical antennomeres clearly longer than trunk. Maxillary palpi long, with slender palpomere 2 and very short palpomeres 1 and 3, apical palpomere broad, with papillae on apical edge (Fig. 18). Labial palpi tiny, with broad apical palpomere and papillae on its margin. Pronotum with seven areoles (Fig. 83), carinae in middle of disc sharp and apparent, more obtuse on margins. Elytra parallel-sided, slightly widened at apex. Four primary and five secondary costae strong over whole elytral length, transverse costae dense, slightly irregular, elytral cells mostly quadrate, often rounded (Figs 52, 54). Legs slender (Fig. 161). Phallus relatively robust, with basal spines and extensively sclerotized internal sac (Figs 127-128). Ovipositor very slender (Fig. 139), vagina constricted, basal part membranous, apical two thirds partly sclerotized (Fig. 143).

Distribution. Australian Region: New Guinea.

Remarks. The flabellate female antennae are the autapomorphy of Pseudodontocerus and this character is not present in other Lycidae. Pseudodontocerus is characterised by the extremely long antennal lamellae in males, weaker lateral and frontolateral pronotal costae, and a slender body shape. I examined type species of Carathix and Pseudodontocerus as well as several closely related undescribed species, and have not found any difference supporting their separate generic status. Therefore, Cara- thrix is considered to be a junior subjective synonym of Pseudodontocerus.

\section{Oriomum Bocak, 1999}

Oriomum Bocak, 1999a: 111.

Type species. Oriomum femoralis Bocak, 1999a: 111.

Diagnosis. Body medium-sized, robust. Head rostrate, rostrum reaching to middle coxae. Antennomeres 1 to 5 slender, antennomere 6 of similar shape but slightly serrate, antennomeres 7-9 short, triangular. Bottom side of antennomeres 1 and 3-4 with very long, dense hairs. Pronotum with 7 areoles. Elytra with four primary costae extending whole length, costa 1 weaker in posterior half. Secondary costae distinct in humeral area, weaker on rest of elytra, cells irregular. Legs significantly modified for clasping of female, with long dense pubesce. Femora of fore legs and mid legs with spines basally. Hind legs with bigger, triangular trochanters. Position of hind process of trochanter corresponds with the position of femoral spines on fore and mid legs. Phallus slender, parallelsided, with exposed, dense pubescence on apical part of internal sac, basal part of internal sac without sclerotisation. Female unknown.

Distribution. Australian Region: New Guinea. Monotypic.

Remarks. Oriomum differs from the remaining Metriorrhynchinae genera in the unique shape of its elytra with entire but apically distinctly weaker first primary costa, the presence of spines on hind margins of fore and mid femora, hind legs with acutely projected triangular trochanters and opistognathous head with extremely long rostrum reaching the coxae of the mid legs, and with antennomeres of a very unusual shape. Oriomum seems to be closely related to the Porrostoma clade, but for the final decision on this a female is necessary.

\section{Cladophorinus Kleine, 1926}

Cladophorinus Kleine, 1926a: 149.

Type species. Cladophorinus cyaneus Kleine, 1926a: 150 (by original designation).

Diagnosis. Body medium sized, slender, slightly widened in posterior quarter, whole body a shiny metallic blue. Head without rostrum. Male antennae flabellate, lamellae slightly longer than trunk of antennomere, lamellae originate from apical part of antennomere. Maxillary palpi moderately long, apical palpomere securiform. Mandibles curved, sickle-like, long. Pronotum with seven areoles, median areola wide, carinae obtuse, partly less distinct. Scutellum deeply emarginate at apex. Elytra with four entire longitudinal primary and five secondary costae, primary costa 1 weaker. Secondary costae considerably weaker, transverse costae obtuse, irregular. Male genitalia slender, phallus widened apically, internal sac partly sclerotized (Fig. 124). Female unknown.

Distribution. Australian Region: New Guinea. Monotypic.

Remarks. Only the damaged holotype of Cladophorinus cyanescens was available for this study. Therefore the genus was not coded into the matrix and is now classified in Metriorrhynchina on the basis of the shape of male genitalia and general appearance. The species is easily 
recognisable by its metallic shine, seven pronotal areoles and flabellate antennae.

\section{Mimoxylobanus Pic, 1921}

Mimoxylobanus Pic, 1921b: 11, hors texte

Type species. Mimoxylobamis angustatus Pic, 1921b: 11 (by monotypy).

Diagnosis. Body small, slender, almost parallel-sided. Head without rostrum. Male antennae apparently compressed, antennomeres 3-10 parallel-sided. Maxillary palpi short, robust, apical palpomere weakly securiform, short. Pronotum only slightly wider at base than long at midline, lateral margins almost parallel-sided, straight. Seven areoles on disc of pronotum, lateral carinae obtuse (Fig. 86). Elytra with four primary longitudinal costae, secondary costae absent, transverse costae irregular, reticulate cells mostly quadrate. All costae distinct, but low in profile. Male genitalia slender, lanceolate, with protracted apical part of internal sac (Figs 131, 132). Female unknown.

Distribution. Australian Region: Sumbawa. Monotypic.

Remarks. Only the holotype of Mimoxylobanus angustatus was available. In general appearance and shape of phallus this species resembles Xylobanus. The exact position of this genus within the Metriorrhynchina is because it differs substantially in the structure of internal sac.

\section{Xylobanomimus Kleine, 1926}

\section{Xylobanomimus Kleine 1926a: 166.}

Type species. Xylobanomimus papuensis Kleine, 1926a: 166 [by original designation, mentioned as $X$. papuanus (sic!)]

Diagnosis. Body small, slender, delicate. Head without rostrum. Male antennae flabellate, lamellae slender, up to four times longer than trunk of antennomere, attached to base on basal segment or middle part on more distal antennomeres. Maxillary palpi slender, long, apical palpomere parallel-sided, apex pointed. Pronotum with seven areoles, middle areola large, lateral carinae obtuse. Elytra with four primary costae, vestiges of secondary costae at humeri. Elytral areoles quadrate to longitudinal. Elytra with sparse, long, erect setae. Phallus robust, parallel-sided, with simple sclerotisation of internal sac (as in Fig. 129). Female unknown.

Distribution. Australian Region: New Guinea. Monotypic genus.

Remarks. Xylobanomimus has very similar male genitalia, general appearance and structure of elytral cells to Malacolycus, but differs in the flabellate male antennae and strong frontolateral carinae on the pronotum. Malacolycus can be hypothesised as a sister group of Xylobanomimus. Xylobanomimus is classified with Metriorrhynchina.

\section{Malacolycus Kleine, 1943}

Malacolycus Kleine, 1943: 151

Type species. Malacolycus paululus Kleine, 1943: 151 (by monotypy).

Diagnosis. Body small, very slender, only slightly sclerotized. Head small, with convex frons and small, but distinct antennal tubercles. Eyes small, hemispherically prominent. Antennae very slender, compressed (Fig. 48). Palpi slender, apical maxillary palpomere pointed. Pronotum with considerably projected posterior angles. Pronotal carinae absent and only an indistinct median areola (Fig. 84). Elytra narrow, 5.5 times longer than their combined width at humeri. Each elytron with four, slender primary costae, costae weak and hardly distinguishable in apical third. Secondary costae absent, transverse costae sparse, elytral cells mostly longitudinal (Fig. 56). Phallus short, stout, with simple sclerotisation of internal sac (Fig. 129). Female unknown.

Distribution. Australian Region: New Guinea. Monotypic genus.

Remarks. Only the holotype of Malacolycus paululus is known. The pronotal carinae are considerably reduced and simple male genitalia are very similar to those of Xylobanomimus. Therefore, Malacolycus is placed in the Metriorrhynchina. The body form and structure of elytra resembles that of Xylobanomorphus, but they differ in male genitalia (Figs 129, 130).

\section{Xylobanomorphus Kleine, 1935}

Xylobanomorphus Kleine, 1935: 316.

Type species. Xylobanomorphus transformis Kleine, 1935: 316 (by monotypy).

Diagnosis. Body small, very slender, delicate, covered with erect setae. Head small, without rostrum, eyes very small, their interocular distance 3.2 times longer than maximum diameter. Antennomeres 3-10 slender, parallelsided. Maxillary palpi slender, apical palpomere pointed. Pronotum with almost parallel-sided lateral margins and projected posterior angles. Only median areola distinct, lateral carinae obtuse, frontolateral carinae absent. Elytra very slender, with four primary longitudinal costae, secondary costae absent. Transverse costae scarce, elytral cells longitudinal (Fig. 56). Male genitalia slender, phallus lanceolate, internal sac extensive with ringshaped sclerotized structure (Fig. 130). Female unknown.

Distribution. Australian Region: New Guinea.

Remarks. At present, only the holotype of Xylobanomorphus transformis is known. This species resembles Xylobanomimus and Malacolycus in general appearance, but differs in the sclerotisation of the internal sac. Considering its similarity to Xylobanomimus, the absent frontolateral pronotal carinae can be hypothesised as secondarily reduced. Several common characters and similarity in general appearance support the affinity of Malacolycus, Xylobanomimus and Xylobanomorphus. All these taxa are known from single specimens of males. Further material is needed for study and provisionally Xylobanomorphus is classified incertae sedis in Metriorrhynchina.

\section{Taxon dubium \\ Falsolucidota Pic, 1921}

Falsolucidota Pic, 1921b: 9, hors texte.

Type species. Falsolucidota testaceicollis Pic, 1921b: 9 (by monotypy). 
Remarks. The identity of the monotypic genus Falsolucidota is unknown. The type specimen was not found in Pic's collection in Paris and the original description does not help in the identification of this taxon.

\section{Key to Metriorrhynchinae genera}

1. Elytral primary costa 1 entire and strong in whole length, weaker in apical half or very slightly shortened; always reaching at least beyond half way along elytra $\ldots \ldots 10$

- Elytral primary costa 1 considerably shortened, never reaching beyond half way along elytra, typically not longer than one third of elytral length (Fig. 9)

2. Pronotum with seven areoles (the same type of arrangement of pronotal carinae as in Figs 69, 71 or 80), only three longitudinal elytral costae (costa 2, 3 and 4) present in the middle of each elytron; costa 1 shortened (as Fig. 9), antennae flabellate (as Fig. 38) . .............. Kassemia

- Pronotum with less than seven areoles (as in figs 62-66) . . 3

3. Pair of vaginal glands inserted dorsally, directed apically or laterally (Bocak, 1998b: Figs 68-70), apical part of phallus narrower than middle part, ventrally open, only dorsal part sclerotized (Figs 103-106)

- Pair of vaginal glands inserted laterally (Fig. 157), apical part of phallus as wide or wider than the middle (Figs 100-102, $115,116)$

4. Pronotum with five areoles (similar to Fig. 70) or with two anteriorly divergent longitudinal carinae (Fig. 66), phallus with pigmented dorsal keel (Figs 105, 106)

- Pronotum with one lanceolate longitudinal areola attached to frontal and basal margins of pronotum at one point (Figs

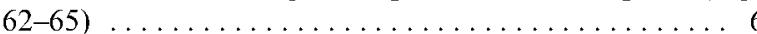

5. Pronotum with five areoles (similar to Fig. 70) ........

Schizotrichalus

- Pronotum with two anteriorly divergent longitudinal carinae (Fig. 66) $\ldots \ldots \ldots \ldots \ldots \ldots \ldots \ldots \ldots$ Eniclases 6. Male antennae flabellate (similar to Figs 44, 47)

Flabellotrichalus

- Male antennae serrate or antennomeres parallel-sided (Figs

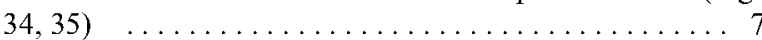

7. Vagina with two lateral pockets medially and with an unpaired very slim and long gland basally (Bocak, 1998b), valvifers slender, usually free, sometimes connected in basal part ...................... Microtrichalus

- Vagina without lateral pockets, unpaired gland absent, valvifers robust, connected subbasally (Bocak, 1998b, Fig. 64)

Trichalus

8. Maxillary and labial palpomeres with distinct sensilae, apical palpomeres broad, securiform (similar to Fig. 18), apical part of phallus projected ventrally, internal sac very complex, sclerotized (Figs 100-101)

Diatrichalus

- Maxillary and labial palpomeres slender, internal sac mostly without sclerotisation, sometimes completely sclerotized (Figs 115-116) .....................

9. Pronotum very slender, longitudinal areola very slender (Fig. 75 ), internal sac membranous or at most with slender sclerotized rods . . . ................. Leptotrichalus

- Pronotum approximately as wide as long, internal sac completely sclerotized, very slender, basally attached to phallus (Fig. 116) ..................... Lobatang

10. Elytral secondary costae absent at least medially (Figs 56, $87,88,90)$

- Elytra with very distinct secondary costae on whole elytra (Figs 44, 45, 48)
11. Elytral secondary costae only absent in middle of elytra, present on basal quarter and apical fifth, internal sac with sclerotized circular gonoporus and basal plates (Fig. 126), elytral cells in middle of elytra transverse ... Procautires

- Elytral secondary costae completely absent or at most vestiges present on small area at the base of pronotum ...... 12

12. Pronotum with small, very slender median areola, connected to frontal margin via strong keel, or median areola very obtuse to absent (Fig. 67), frontal margin formed by two strong carinae (Fig. 67), elytral areoles quadrate, with mat, velvet-like bottoms, found only in Madagascar

Caenioxylobanus

- Pronotum with different arrangement of carinae (Figs 57, 60, $69,70,72,84)$, frontal margin of pronotum simple ... 13

13. Male genitalia with parameres (as in Fig. 91), at most parameres shortened .............. Xylobanellus

- Parameres absent (Figs 92-130) . . . . . . . . . . 14

14. Pronotum with five areoles, pronotal carinae slender, straight (as in Fig. 60), phallus very slender with one complex spine at base or in middle part of phallus, apical part often rotated (Fig. 94)

Wakarumbia

- Pronotum with differently arranged pronotal carinae, always at last vestiges of frontolateral carinae present (Figs 69-83) or only one unapparent median areola present (Fig. 84), internal sac with two spines in various positions (Figs 107-112, 121-128) or without spines (Fig. 130) . . . 15

15. Most elytral cells distinctly longitudinal (Fig. 56), body very slender, minute, delicate, pronotum costae obtuse, indistinct, pronotum with one inconspicuous areola (Fig. 84) or vestiges of lateral and frontolateral carinae present $\ldots \ldots 16$

- Elytral cells quadrate to transverse, body medium sized to moderately large, pronotum always at least with vestiges of frontolateral carinae (Figs 69-83) . . . . . . . . 18

16. Phallus parallel-sided with rounded apex, internal sac with two sclerotized rods (Fig. 128) $\ldots \ldots \ldots \ldots \ldots \ldots 17$

- Phallus slender, narrowed to apex, internal sac with ringshaped sclerotised structure (Fig. 130)

Xylobanomorphus

17. Male antennae flabellate, vestiges of pronotal lateral and frontolateral costae present .......... Xylobanomimus

- Male antennomeres parallel-sided (Fig. 48), only indistinct median areola present (Fig. 84) ......... Malacolycus

18. Bottom of elytral cells shiny, apparently concave, quadrate (Fig. 90), elytra more or less dilated, convex, pronotal lateral carinae always indistinct to absent (Fig. 70), male genitalia as in Fig. 111 .................. Broxylus

- Bottom of elytral cells mat, pubescent, elytra parallel-sided to very slightly dilated, flat $\ldots \ldots \ldots \ldots \ldots \ldots \ldots$

19. Elytra with three longitudinal primary costae running whole length of elytra $\ldots \ldots \ldots \ldots \ldots \ldots$ Prometanoeus part

- Elytra with four longitudinal primary costae running whole

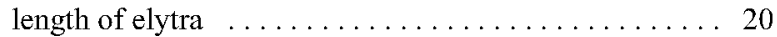

20. Pronotum with seven areoles, lateral carinae regularly well developed, seldom lateral carinae more obtuse, internal sac with pair of spines apically, male antennae serrate to flabellate (as in Figs 38, 39) . . . . . . . . . Xylobanus

- Pronotum with seven areoles, lateral carinae obtuse, internal sac without spines, and the internal sac with a very slender apical part (Figs 131-132) . . . . . . Mimoxylobanus

21. Male genitalia with parameres (Fig. 91), unpaired vaginal gland inconspicuous, pronotum as in Fig. 58 ... Conderis

- Male genitalia without parameres (Figs 92-130), unpaired vaginal gland large (Figs 163-159), pronotum with carinae

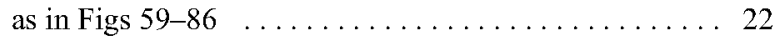

22. Elytra with three longitudinal primary costae running whole length of elytra ............. Prometanoeus part 
- Elytra with four longitudinal primary costae running whole length of elytra $\ldots \ldots \ldots \ldots \ldots \ldots \ldots \ldots \ldots 23$

23. Frontolateral carinae on pronotum absent (Figs 59-60,68) .

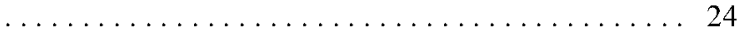

- Frontolateral carinae on pronotum present (Figs 69-74,

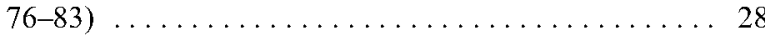

24. Pronotum with very obtuse frontal angles, distinctly narrowed anteriorly, with one small, slender median areola connected with frontal margin by strong keel, lateral carinae absent (Fig. 68), phallus lanceolate, internal sac with pair of spines (Fig. 107), male antennae flabellate as in Fig. 38 ...

Bulenides

- Pronotum with conspicuous frontal angles, lateral carinae present to vestigial, median areola more extensive (Figs 59-61)

25. Lateral carinae apparent, median areola rhomboidal (Figs 59-60), pronotal carinae usually straight, slender, phallus slender as in Fig. 92 or robust (Fig. 95, 96), with paired spines or spines arranged linearly, male genitalia slender, spermatheca bulbous ................. 26

- Lateral carinae vestigial, male genitalia as in Figs 97-99, spermatheca tubular, very long ............. Enylus

26. Elytral primary costa 3 reaching mid way along elytra, spines on internal sac arranged linearly, bases of valvifers with various processes, male antennae as long as body

Hemiconderis

- Elytral primary costa 3 reaching beyond middle of elytra, usually complete although weaker apically, spines on internal sac as in Figs 92-96, bases of valvifers without any process, male antennae shorter than body ............ 27

27. Body very slender, fragile, almost parallel-sided, secondary costae very weak, phallus short, slender (Figs 95-96)

- Body small, but moderately robust, widened posteriorly, secondary costae well developed, phallus slender (Figs 92-93)

Synchonnus

28. Head with long rostrum (Fig. 10), phallus slender, tubular, internal sac completely membranous (Figs 117-120) . . 29

- Head without rostrum (Fig. 11) or head only slightly protracted, internal sac usually at least partly sclerotized (Figs $107-114,121-128)$

29. Elytra considerably widened posteriorly, both ventral and dorsal surface of body a distinctly shiny metallic blue ....

Metriorrhynchoides

- Elytra slender, parallel-sided to slightly widened posteriorly, sometimes only ventral surface of body a shiny metallic blue .............................. 30

30. Antennae with slender, long basal antennomeres and short, triangular apical antennomeres, antennae with long, dense setae, fore and mid femora with spines, hind trochanters triangular ..................... Oriomum

- Antennae serrate to flabellate, all antennomeres subequal, without long setae, femora without spines, trochanters slender

Porrostome

31. Male antennae with extremely long and very slender, fragile lamellae (Fig. 45), female antennae with short lamellae (Figs 46-47)

Pseudodontocerus

- Male antennae serrate to flabellate (Figs 38-43) or with long but moderately slender lamellae (Figs 44, 51), female antennae never flabellate $\ldots \ldots \ldots \ldots \ldots \ldots \ldots . \ldots 32$

32. Phallus tubular, with completely membranous internal sac, valvifers fused with coxites, lateral and frontolateral pronotal carinae sometimes vestigial ......... Stadenus

- Phallus different, never with completely membranous internal sac, valvifers free, frontolateral and lateral pronotal carinae always distinct $\ldots \ldots \ldots \ldots \ldots \ldots \ldots \ldots \ldots \ldots$
33. Phallus lanceolate, internal sac with pair of spines apically (Fig. 108), no body part shiny metallic blue ... Cautires

- Phallus parallel-sided, tubular, shorter, body often a shiny metallic blue ....................... 34

34. Pronotal carinae robust but obtuse, indistinct, male antennae with long, relatively slender lamellae (Fig. 40), male genitalia parallel-sided (Fig. 113) or robust basally, internal sac with several pairs of processes (Fig. 113), ovipositor with considerably shortened valvifers (Fig. 150), lateral glands sometimes attached dorsally and directed upwards, spermaduct often extremely long ........... Metanoeus

- Pronotal carinae moderately strong and well marked, sometimes partly reduced, male genitalia never with apical processes, usually with variously shaped plates or spines, valvifers never considerably shortened (Figs 140, 152, 160), lateral glands attached laterally or lateroventrally, spermaduct moderately long . . . . . . . . . . . . . . 35

35. Body often large, slender, internal sac of phallus spirally sclerotised (Fig. 114), or with straight sclerotisation and several pairs of adjacent, small, simple spines (Bocak, 1998c, Figs 1,2), ovipositor very small, lightly sclerotized, partly membranous (Fig. 134), vagina often considerably sclerotized ................ Metriorrhynchus

- Body mostly medium-sized, phallus without any slender, rodlike sclerotized structure (Figs 121-125, 127-128), ovipositor well sclerotized (Figs 140), vagina never strongly sclerotized ......................... 36

36. Membrane of phallobase extensive, pigmented, with characteristic structure (Fig. 121), phallus narrowed to apex, male antennae with very long lamellae (Figs 44, 51)

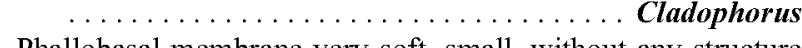
without any structure (Figs 122-125), never considerably narrowed at apex, male antennae serrate or with short lamellae, lamellae at most twice length of body of antennomere . . . . . . . . 37

37. Body metallic blue, male antennae flabellate, phallus slender (Fig. 124) ................ Cladophorinus

- Body otherwise coloured, never metallic blue ...... 38

38. Male antennae serrate, male genitalia as in Fig. 125 ...... ........................... Ditua

- Male antennae flabellate, male genitalia as in Figs 122-123

Cautiromimus

\section{Genus excluded from the subfamily Metriorrhynchinae}

Lycoprogenthes Pic, 1915

Lycoprogentes Pic, 1915: 6

Type species. Lycoprogentes pouilloni Pic, 1915: 6 (by monotypy).

Pseudosynchonnus Pic, 1922 - syn. n.

Pseudosynchonnus Pic, 1922: 13, hors texte.

Type species. Pseudosynchonnus testaceus Pic, 1922: 13 (hereby designated).

Parapyropterus Kleine, 1926c: 104 - syn. n.

Type species. Parapyropterus nigrostriatus Kleine, 1926c: 104 (by monotypy).

Protaphes Kleine, 1926b: 363 - syn. n.

Type species. Protaphes confertus Kleine, 1926b: 364 (by original designation).

Pseudosynchonnus is here transferred from the Metriorrhynchinae to Erotinae and Lycoprogenthes from Calochrominae to Erotinae. I have compared Pseudosynchonnus, Lycoprogenthes, Parapyropterus and Protaphes (the last two already sooner classified in Erotinae) and I 
have not found any substantial difference between them Therefore, I consider genera Pseudosynchonnus, Parapyropterus, and Protaphes to be junior synonyms of $L y c o-$ progenthes.

\section{Appendix 1: List of type material studied.}

Subfamily Metriorrhynchinae Kleine, 1926

Tribe Conderini Bocak et Bocakova, 1990

Conderis C. O. Waterhouse, 1879: 59. Calopteron signicolle Kirsch, 1975: Holotype, 1 spec., "Malacca" (SMTD).

=Pseudoconderis Pic, 1921 a: 8, hors texte. Pseudoconderis gorhami Pic, 1921a, Holotype, female, "India, coll. Armitage (MHNP).

Xylobanellus Kleine, 1930b: 171. Xylobanellus atricolor Kleine, 1930b: Holotype, female, "Malay. Penin. Selangor, Bukit Kuta" (BMNH).

= Rossioptera Kasantsev, 1988: 169. Eros erythropterus Baudi, 1871. The type of E. erythropterus was not studied.

Chuzenjianus Nakane, 1969: 176. Conderis tenuis Kôno, 1932. The type species was not examined.

\section{Tribe Metriorrhynchini Kleine, 1926}

\section{Subtribe Hemiconderina Bocak et Bocakova, 1990}

Synchonnus C. O. Waterhouse, 1879: 59. Porrostoma clientulum C. O. Waterhouse, 1877: Syntype, male, "Moreton Bai" (BMNH).

Strophicus C. O. Waterhouse, 1879: 73. Strophicus nigellus C. O. Waterhouse, 1879: Holotype, female, "Mysool" (BMNH).

Hemiconderis Kleine, 1926a: 162. Hemiconderis explicatus Kleine, 1926a: ?Paratype, male, "Mamberamo R., W. G. v. Heuer, 20. xii. - 21. i. Pionierbivak" (MIZW).

Wakarumbia Bocak, 1999b: 166. Wakarumbia gracilis Bocak, 1999: Holotype, male, "Sulawesi SE, Buton Island, Wakarumba, 3.-7. ii. 1994, M. Štrba and I. Jeniš lgt." (LMBC). Achras C.O. Waterhouse, 1879: 61. Porrostoma limbatum C. O. Waterhouse, 1877: Holotype, male, "Austral. 73-6" (BMNH)

\section{Subtribe Trichalina Kleine, 1928}

Enylus C.O. Waterhouse, 1879: 72. Enylus segregatus C. O. Waterhouse, 1879: Holotype, female, "Mysool" (BMNH).

Diatrichalus Kleine, 1926a: 167. Diatrichalus xylobanoides Kleine, 1926a: Holotype, male, "D.N. Guinea, 285, Hunsteinspitze, 3. iii. 43, Kais. Augustafl. Exp., Bürgers S.G." (NHMB).

= Mimotrichalus Pic, 1930: 92, hors texte. Mimotrichalus tenimberensis: Holotype, male, "Tenimber Is, Coll. by W. Doherty" (MNHP).

Trichalus C. O. Waterhouse, 1877: 82. Trichalus flavopictus C. O. Waterhouse, 1877: Holotype, male, "Port Bowen, 75.22" (BMNH).

= Xantheros Fairmaire, 1877: 167. The type of Xantheros ochreatus Fairmaire, 1877 was destroyed during the World War II in Hamburg (Bocak, 1998b).

Microtrichalus Pic, 1921b: 9, hors texte. Microtrichalus singularis Pic, 1921b: Holotype, male, "?Java" (MHNP).

= Falsoenylus Pic, 1926a: 29, hors texte. Falsoenylus basipennis Pic, 1926a: Holotype, female, "Baguio, Luzon" (MNHP).

Flabellotrichalus Pic, 1921b: 9, hors texte. Flabellotrichalus notatithorax Pic, 1921b: Syntype, male, "Batjan, Aug-Septbr." (MHNP).

= Villosotrichalus Pic, $1921 \mathrm{~b}: 9$, hors texte. Villosotrichalus reductus Pic, 1921b: Syntypes, male, female, "Andai, Nlle Guinée" (MHNP).
Schizotrichalus Kleine, 1926a: 2, p. 183. Trichalus nigrescens C.O. Waterhouse, 1879: Holotype, male, "Mysool" (BMNH).

Eniclases C. O. Waterhouse, 1879: 66. Lycus (gen. 35) luteolus C.O. Waterhouse, 1878: Holotype, male, "Bowring 63.47*" (BMNH).

= Trichalolus Pic, 1923: 36, hors texte. Trichalus (Trichalolus) apertus Pic, 1923: Holotype, female, "Andai, Nle Guinée" (MNHP).

\section{Subtribe Metriorrhynchina Kleine, 1926}

Bulenides C.O. Waterhouse, 1879: 34: Lycus (gen. 21) obsoletus C. O. Waterhouse, 1878: Holotype, female, "Java" (BMNH).

Caenioxylobanus Pic, 1922: 13, hors texte. Caenioxylobanus ater Pic, 1922: Holotype, female, "Madagascar, collection Le Moult, Janvier" (MHNP).

Cautires C.O. Waterhouse, 1879: 36. Lycus (gen. 22) excellens C. O. Waterhouse, 1878: Holotype, male, "Sar." (= Sarawak) (BMNH).

Prometanoeus Kleine, 1925c: 133. Prometanoeus ochraceus Kleine, 1926b: Holotype, male, "Ceylon, G. Lewis, 1910-320; Dikoya, 3800-4200ft, 6. xii. 81-16. i. 82” (BMNH)

Tapromenoeus Bocak et Bocakova, 1989: 327. Xylobanus hirtus Kleine, 1928: 234. Paratype, male, "Dikoya, Ceylon" (MIZW).

Broxylus C.O. Waterhouse, 1879: 20. Calopteron pfeifferi C. O. Waterhouse, 1878: Holotype, male, "Celebes, Wallace" (BMNH).

= Samanga Pic, 1921b: 9, hors texte. Samanga fenestrata Pic, 1921b: Holotype, male, "Samanga, S. Celebes, Nov, 1895, H. Fruhstorfer" (MHNP).

Xylobanus C. O. Waterhouse, 1879: 38. Lycus costifer Walker, 1858: Holotype, male, "Ceylon" (BMNH).

Mimoxylobanus Pic, 1921b: 11, hors texte. Mimoxylobanus angustatus Pic, 1921b: Holotype, male, "Sumbawa, Doherty" (MHNP).

Metriorrhynchus Gemminger et Harold, 1869: 1629. The type of Metriorhynchus parallelus Guérin-Méneville, 1838 was not found in either Brussels or Paris Museums and was very probably destroyed during a fire in the Brussels Museum (L. Baert, pers. comm.).

= Metriorhynchus Guérin-Méneville, 1838: 72 (unavailable senior objective synonym of Metriorrhynchus Gemminger et Harold.

= Flabelloporrostoma Pic, 1923: 35, hors-texte. Porrostoma (Flabelloporrostoma) mirabilis Pic, 1923: Holotype, female, "N. S. Wales" (MHNP).

Leptotrichalus Kleine, 1925a: 296. Metriorrhynchus cyaniventris Kirsch, 1875: Holotype, female, "Malacca" (SMTD).

Lobatang Bocak, 1998b: 190. Lobatang papuensis Bocak, 1998b: Holotype, male, "Irian Jaya: Jayawijaya, Bime, 1600-1900 m, 11. 9. 1993, leg. A. Riedel" (SMNS).

Metanoeus C.O. Waterhouse, 1879: 73. Lycus (gen. 37) conformis C.O. Waterhouse, 1878: Holotype, male, "Borneo" (BMNH).

Stadenus C.O. Waterhouse, 1879: 61. Porrostoma dichroum C. O. Waterhouse, 1977: Holotype, female, "K. George's Pound, 75-36" (BMNH).

Porrostoma Castelnau, 1838: 26. Porrostoma rufipennis Fabricius, 1801: The specimen compared with Fabricius' type was available for study (O. Martin, pers. comm.).

Metriorrhynchoides Kleine, 1926a: 118. Metriorrhynchoides helleri Kleine, 1926a: Paratype, male, "K. Wilhelmland, Bongu" (MIZW).

Oriomum Bocak, 1999a: 111. Oriomum femoralis Bocak, 1999c: Holotype, male, "New Guinea: Papua, W. District Govt. Sta. 26.-28. x. 1960, J. L. Gressitt Collector" (BPBM). 
Cladophorus Guérin-Méneville, 1830: Plate II, Fig. 9. The type of Cladophorus formosus Guérin-Méneville, 1830 was not found in the Brussels or Paris Museums and was very probably destroyed during a fire in the Brussels Museum (L. Baert, pers. comm.).

= Odontocerus Guérin-Méneville, 1838: 72 (a homonym of Odontocerus Stephens, 1829 (Trichoptera)).

=Spacekia Strand, 1936: 169; Bocak, 1998c: 247 (a objective synonym of Metriorrhynchus Guérin-Méneville, 1830).

Cladophorinus Kleine, 1926a: 149. Cladophorinus cyanescens Kleine, 1926a: Holotype, male, D. N. Guinea, Schradenbg., 5.-13.vi. 13, Kais. August. Exp., Bürgers S. C. (MIZW).

Cautiromimus Pic, 1926c: 454. Cautiromimus reticulatus Kleine, 1926a: Holotype, female, "Batjan, Aug-Septbr. ex coll. H. Fruhstorfer" (DEIE).

Procautires Kleine, 1925b: 32. Procautires toxopei Kleine, 1925: Paratype, female, "Buru Stn. 13, Toxopeus" (MIZW).

Ditua C.O. Waterhouse, 1879: 33. Lycus (gen. 20) deplanatus C.O. Waterhouse, 1878: Holotype, male, "59.58, Dory, New Guinea" (BMNH).

Kassemia Bocak, 1998b: 195. Kassemia oculata Bocak, 1998b Holotype, male, "New Guinea, NE Wau, 1200-1300 m, 22. x.1965, J. Sedlacek Collector Bishop Mus." (BPBM).

Pseudodontocerus Pic, 1921b: 12, hors texte. Pseudodontocerus pulcher Pic, 1921b: Holotype, female, "Humboldt Bay, N. Guinea, Doherty" (MHNP).

=Carathrix Kleine, 1926a: 149. Carathrix pilosus Kleine, 1926a: Holotype, male, Paumonu Riv. ix. - xii. 92" (MSNG).

Xylobanomimus Kleine, 1926a: 166. Xylobanomimus papuensis Kleine, 1926a, Holotype, male, "N. Guinea, Dilo, Loria, vi-vii 90" (MSNG).

Xylobanomorphus Kleine, 1935: 316. Xylobanomorphus transformis Kleine, 1935: Holotype, male, "Papua: Mt. Tafa, $8500 \mathrm{ft}$, ii. 1934, L. E. Cheesman, B. M. 1934-244" (BMNH).

Malacolycus Kleine, 1943: 151. Malacolycus paululus Kleine, 1943: Holotype, male, "N. Guinea, Biró, 901, Friedrich-Wilh.-hafen" (HNHM).

Dilolycus Kleine, 1926a: 186. Dilolycus lamellatus Kleine, 1926a: Holotype, male, "N. Guinea, Dilo, Loria, vi-vii 90" (MSNG).

\section{Genera classified outside the Metriorrhynchinae}

Lycoprogentes Pic, 1915: 6. Lycoprogenthes Pic, 1915: 6. Lycoprogenthes pouilloni Pic, 1915: Holotype, female, "Darjeling, Pouillon" (MNHP).

= Pseudosynchonnus Pic, 1922: 13. Pseudosynchonmus testaceus Pic, 1922: 13: Holotype, male, "Perak" (MHNP).

= Protaphes Kleine, 1926b: 363. Protaphes confertus Kleine, 1926b: 364: Holotype, male, "Mindanao, Surigao" (MIZW).

ACKNOWLEDGEMENTS. This study was made possible by a grant from the Czech Grant Agency (Project 206/98/0539). The following individuals and institutions are gratefully acknowledged for loan of material: L. Baert (Museum d'Histoire naturelle, Brussels), B. Brugge (Zoological Museum, Amsterdam), T. Huflejt and S. A. Slipinski (Museum and Institute of Zoology, Warszawa), M. Kerley and J. Beard (Natural History Museum, London), J. Krikken (Natural History Museum, Leiden), J. J. Ménier (Museum national d'Histoire naturelle, Paris), K. Matsuda (Takarazuka City, Japan), O. Merkl (Natural History Museum, Budapest), R. Poggi (Museo Civico di Storia Naturale, Genova), W. Schawaller (Staatliches Museum für Naturkunde, Stuttgart), M. Uhlig (Zoologisches Museum, Berlin), G. A. Samuelson (State Museum of Natural and Cultural History, Honolulu), and H. Schönmann (Naturhistorisches Museum, Wien).

\section{REFERENCES}

Bocak L. 1998a: New and little known species of Conderini and Ateliini (Coleoptera: Lycidae). Acta Univ. Pal. Olom., Biologica 36: 17-26.

BocAK L. 1998b: A generic revision and phylogenetic analysis of the subtribe Trichalinina (Coleoptera: Lycidae: Metriorrhynchini). Acta Soc. Zool. Bohem. 62: 167-200.

BoCAK L. 1998c: Nomenclatural notes on taxa of the family Lycidae described by Guérin-Méneville (Insecta: Coleoptera). Ann. Zool. 48: 245-251.

BOCAK L. 1998d: A revision of the genus Microtrichalus Wat. from the Philippines (Coleoptera: Lycidae). Eur. J. Entomol. 95: 417-428.

BOCAK L. 1998e: A new species of the genus Eniclases Wat. (Coleoptera, Lycidae). Acta Univ. Pal. Olom., Biologica 35: 13-16.

BOCAK L. 1999a: A new genus Oriomum from New Guinea (Coleoptera: Lycidae: Metriorrhynchini). Entomol. Basiliensia 21: 111-114.

BOCAK L. 1999b: New taxa of the subtribe Hemiconderinina (Coleoptera: Lycidae) from Indonesia and New Guinea. Entomol. Bl. 95: 166-170.

BOCAK L. 2000a: A revision of the genus Diatrichalus Kleine from the Philippines. Raffl. Bull. Zool. 48: 11-16.

BOCAK L. 2000b: To the knowledge of the genus Leptotrichalus Kleine from Sumatra, Borneo and continental Asia (Coleoptera: Lycidae). Ann. Soc. Entomol. Fr. (N. S.) 36: 171-184.

BocAK L. 2000c: A revision of the genus Wakarumbia (Coleoptera: Lycidae). Eur. J. Entomol. 97: 271-278.

BOCAK L. 2000d: A revision of the Microtrichalus from Sumatra, with notes on Oriental and Australian species (Coleoptera: Lycidae). Acta Soc. Zool. Bohem. 64: 3-16.

BOCAK L. 2001a: A revision of the genus Diatrichalus Kleine from New Guinea (Coleoptera: Lycidae). Stuttgarter Beitr. Naturk., Ser. A. 622: 1-32.

BocAK L. 2001b: New species of the genus Wakarumbia from Sulawesi (Coleoptera: Lycidae). Raffles Bull. Zool. 49:1-9

BocAK L. \& JAšš R. (in press): Revision of the genus Broxylus Waterhouse (Coleoptera, Lycidae). Deutsche Entomol. Zeitschr.

BOCAK L. \& BOCaKova M.1987a: Notes on the taxonomy of some European species of the family Lycidae (Coleoptera). Acta Entomol. Bohemoslov. 84: 111-121.

BocaK L. \& Bocakova M. 1987b: A review of Lycidae (Coleoptera) from Taiwan, with a description of a new species. Acta Entomol. Bohemoslov. 84: 273-286.

BocaK L. \& BocaKova M. 1989: Contribution a l'étude des Lycides de l'ile Sri Lanka, III. Cladophorini (Coleoptera, Lycidae). Deutsche Entomol. Zeitschr. 36: 321-328.

BocaK L. \& Bocakova M. 1990a: Revision of the supergeneric classification of the family Lycidae (Coleoptera). Polskie Pismo Entomol. 59: 623-676.

Bocak L. \& Bocakova M. 1990b: Revision of the genus Hemiconderis (Coleoptera, Lycidae). Acta Entomol. Bohemoslov. 87: 209-220.

Bocak L. \& Bocakova M. 1991: Revision of the genus Eniclases C. O. Waterhouse, 1879 (Coleoptera: Lycidae: Metriorrhynchinae). Mitt. Münch. Entomol. Ges. 81: 203-226.

BocaK L. \& Bocakova M. 1992: Notes on some genera of the family Lycidae (Insecta: Coleoptera). Entomol. Basiliensia 15: 255-260.

BOCAK L. \& Bocakova M. 1999: New taxa of Lycidae from China and Indonesia. Acta Univ. Pal. Olom., Biologica 37: $47-56$. 
BocaK L. \& Matsuda K. 1998: A review of the Metriorrhynchus thoracicus group (Coleoptera: Lycidae). G. Ital. Entomol. 8: 409-415.

BocaK L. \& MATsuda K. in press: Review of the immature stages of the family Lycidae (Insecta: Coleoptera). J. Nat. Hist.

BocAKova M. 2001: Revision and phylogenetic analysis of the subfamily Platerodinae (Coleoptera: Lycidae). Eur. J. Entomol. 98: 53-85.

Bocakova M. in press: Revision of the tribe Calopterini (Coleoptera: Lycidae). Stud. Neotrop. Fauna Env.

Borsduval J.B.A. 1835: Faune entomologique de l'Océanie, comprenant les Coléoptères, les Hemiptères, les Nevroptères, les Hymenoptères et les Diptères. Bd. 1. Roret, Paris, 267 pp.

BOURGEOIS J. 1891: Études sur la distribution géographique des Malacodermes. I. Lycides. Ann. Soc. Entomol. Fr. 60: 337-364.

Bourgeors J. 1892: Lycides nouveaux ou peu conmus du Musée civique de Genes. Ann. Mus. Civ. Stor. Nat. Genova 12: 495-516.

BuraKowsKI B. 1988: Notes on the biology of Xylobanellus erythropterus (Baudi a Selve) (Coleoptera: Lycidae), with description of the immature stages. Polskie Pismo Entomol. 58: $575-585$.

CALDER A.A. 1998: Coleoptera: Elateroidea. In Wells A. (ed.) Zoological Catalogue of Australia. Volume 26.9. CSIRO Publishing, Melbourne, xiii $+248 \mathrm{pp}$.

Castelnau Laporte De F.L. 1838: Études entomologiques ou descriptiones des insectes nouveaux et observations sur leur synonymie. Rev. Entomol. 4: 5-60.

ERICHSON W.F. 1842: Beitrag zur Fauna von Vandiemensland, mit besonderer Ruecksicht auf die geographische Verbreitung der Insecten. Weigeman Archiv 8: 83-287.

FABRICIUS J.C. 1775: Systema Entomologiae, sistens insectorum classes, ordines, genera, species, adiectis synonymis, locis, descriptionibus, observationibus. Korte, Flensburgi et Lipsiae, xxvii $+832 \mathrm{pp}$.

Fabricius J.C. 1801: Systema Eleutheratorum... Bibliopol. Acad, Kiliae, Tom 1, xxiv +506 pp.

Farrmarre L.M. 1877: Diagnoses des Coléoptères australiens et melanesiens. Petit Nouv. Entomol. 2: 166-167.

FARRIS J.S. 1988: Hennig 86, Version 1.5. Documentation published by the author. Port Jefferson, NY.

FuKUdA A. \& HaYashi N. 1981: Coleoptera: Lycidae. In Esaki T. et al., Illustrated Insect Larvae of Japan, 7th edition. Hokuryukan Co., Ltd., Tokyo, pp. 431-432. [in Japanese]

Gemminger M. \& Harold von E. 1869: Catalogus Coleopterorum hucusque descriptorum synonymicus et systematicus. Band 6. Rhipiceridae-Cionidae. E. Deyrolle fils, Paris, pp. $1609-1800$

GứRIN-MéNeville F.L. 1830: Crustacés, arachnides et insectes In: Duperrey L.I. (ed.): Voyage autour du monde...sur la corrette de Sa Majesté, La Coquille, pendant les annés 1822 1823, 1824 et 1825.... Bertrand, Paris, Zoologie, 22 col. plates.

GúRIN-MÉNEVILle F.C. 1838: Crustacés, arachnides et insectes. In Duperrey L. I. (ed.): Voyage autour du monde ...sur la Corvette de Sa Majesté, La Coquille, pendant les annés 1822, 1823, 1824 et 1825 ... Bertrand, Paris, Zoologie, vol. 2, part 2, pp. 24-26.

Hayashi N. 1954: Larva and Pupa of Lyponia quadricollis Kiesenwetter. Studies on Coleopterous Larvae I. New Entomologist 3: $10-15$.

HaYAshI N. 1986: Key to the families of Coleoptera based on the larval characters. In Morimoto, K. \& Hayashi, N. (eds):
The Coleoptera of Japan in Color, Volume I. Hoykusha Publishing Co., Osaka, 218 pp. [in Japanese]

KASANTSEV S.V. 1988: To the knowledge of net winged beetles (Coleoptera: Lycidae). On the status of species Dictyoptera erythroptera Baudi. Fauna i Ekologija Nasekomych Vietnama 1988: 168-170 [in Russian].

Kirsch T. 1875: Neue Käfer aus Malacca. Mitt. Dresd. Mus. 1: $25-58$

Kleine R. 1925a: Die neue Gattung Leptotrichalus. Philippine J. Sci. 28: 295-311.

Kleine R. 1925b: Fauna Buruana. Coleoptera, Fam. Lycidae (2. Beitrag zur Kenntnis der Lycidae). Treubia 7: 31-37.

KLEINE R. 1925c: Drei neue Lycidengenera des orientalischen Gebietes. 8. Beitrag zur Kenntnis der Lycidae. Stett. Entomol. Zeit. 85: 133-136.

Kleine R. 1926a: Coleoptera, Lycidae. Nova Guinea, Zoologie 15: 91-195.

KLeine R. 1926b: Protaphes, a new Lycid-genus from Sarawak. Sarawak Mus. J. 10: 363-365.

KLeINE R. 1926c: Die Lyciden Formosas. Stett. Entomol. Zeit. 87: $97-110$

KLeINE R. 1928: Neue Indische Lycidae nebst faunistische Bemerkungen. Indian Forest Rec. 13: 221-268.

Kleine R. 1930a: Bestimmungtabelle der Trichalusverwandschaft. Treubia 11: 325-341.

Kleine R. 1930b: Neue Lyciden der malaiischen Subregion. Journ. Fed. Malay. Stat. Mus. 16: 169-174.

Kleine R. 1933: Lycidae. Pars 128. In Junk W. \& Schenkling S. (eds): Coleopterorum Catalogus. W. Junk, Berlin, pp. 1-145.

Kleine R. 1935: Bericht ueber die von Miss Cheesman in British New Guinea gesammelten Brenthiden und Lyciden. Nova Guinea, Zoologie 17: 302-322.

KLeine R. 1936: Check list of Pacific Lycidae. Bernice Pauhu Bishop Mus. Occ. Pap. 12: 1-7.

KLerNe R. 1943: Neue Lyciden aus dem Ungarischen NationalMuseum (Coleopt.) Acta Mus. Nat. Hung., Zoologica 36: $145-156$.

LAWrence J.F. \& Britton E.B. 1991: Coleoptera. In CSIRO The Insects of Australia. Melbourne University Press, Melbourne, $\mathrm{xvi}+1137 \mathrm{pp}$.

MEYER vON H. 1830: ["Eine Reihe von eingenhandigen Abbildungen von Resten thierischer Organismen"] Isis 23: columns 517-519.

MoORE B.P. \& BRown W.V. 1981: Identification of warning odour components, bitter principles and antifeedants in an aposematic beetle - Metriorrhynchus rhipidium (Coleoptera: Lycidae). Insect Biochem. 15: 493-499.

NAKane T. 1968: On Some New Species of Lycidae from Formosa (Insecta: Coleoptera). Bull. Nat. Science Mus. 11: 217-224.

Nakane T. 1969a: Fauna Japonica, Lycidae (Insecta: Coleoptera). Academic Press of Japan, Tokyo, $224 \mathrm{pp.}$

NAKANE T. 1969b: New Species of Lycidae from Formosa, with Notes on Some Known Species (Insecta: Coleoptera). Bull. Nat. Science Mus. 12: 9-16.

NakANe T. 1971: Formosan Lycidae in the Collection of the California Academy of Sciences (Insecta: Coleoptera). Bull. Nat. Science Mus. 14: 137-155.

NAKANE T. 1980: New or Little-Known Coleoptera from Japan and its Adjacent Regions, xxxii. Rep. Fac. Science Kagoshima Univ. (Earth Sciences and Biology) 13:127-130.

Nixon K.C. 1998: Clados, Version 1.83. IBM PC-compatible character analysis program. Documentation published by the author. 
PIC M. 1915: Genres nouveaux, éspèces et variétes nouvelles. Mélanges Exotico-entomologiques 16: 2-13.

PIC M. 1921a: Contribution à l'étude des Lycides. L'Echange 405: 5-8 hors-texte.

PIC M. 1921b: Contribution à l'étude des Lycides. L'Echange 406: 9-12 hors-texte.

PIC M. 1922: Contribution à l'étude des Lycides. L'Echange 407: 13-16 hors-texte.

PIC M. 1923: Contribution à l'étude des Lycides. L'Echange 412: $35-36$ hors-texte.

PIC M. 1926a: Contribution à l'étude des Lycides. L'Echange 425: $29-30$ hors-texte

PIC M. 1926b: Malacodermes exotiques. L'Echange 423: 22 hors-texte.

PIC M. 1926c: Nouveaux Coléoptčres du Globe. Bull. Soc. Zool. Fr. 51: 454 pp.

PIC M. 1926 d: H. Santer's Formosa Ausbeute. Mordellidae, Lycidae, Centharidae. Entomol. Mitt. 15: 67-69.

PIC M. 1930: Malacodermes exotiques. L'Echange 442: 92 horstexte.

PotozkAJA V.A. 1981: Morphology and ecology of larvae of Coleopterous genera Aplatopterus Rtt. and Xylobanus C.O. Waterhouse (Coleoptera: Lycidae). Entomol. Obozr. 60: 337-347 [in Russian].
Ramos T.C. 1997: Tree Gardened 2.2. Software published by author. Museum de Zoologia, Sao Paulo.

STEPHENS J.F. 1829: Illustrations of British Entomology, or a Synopsis of indigenous Insects, ... Baldwin \& Cradock, London, $374 \mathrm{pp}$.

Strand E. 1936: Miscellanea nomenclatorica zoologica et palaeontologica. Fol. Zool. Hydrobiol. (Riga) 9: 167-170.

WALKeR F. 1858: Characters on some apparently undescribed Ceylon Insects. Ann. Mag. Nat. Hist. 2: 280-286.

WATERHOUSE C.O. 1877: A Monograph of the Australian species of the Coleopterous family Lycidae. Trans. Entomol. Soc. Lond. 1877: 73-86.

Waterhouse C.O. 1878: On the different forms occurring in the Coleopterous family Lycidae, with descriptions of new genera and species. Trans. Entomol. Soc. Lond. 1878: 95-118.

Waterhouse C.O. 1879: Illustration of the Typical Specimens of Coleoptera in the Collection of the British Museum. Part I. Lycidae. British Museum, London, 93 pp.

Watrous L.E. \& Wheeler Q. D. 1981: The out-group comparison method of character analysis. Syst. Zool. 30: 1-11.

WIENS J.J. 1998: Does Adding Characters with missing data Increase or Decrease Phylogenetic Accuracy? Syst. Biol. 47: 625-640.

Received February 2, 2001; revised November 20, 2001, accepted January 16, 2002 